\author{
UNIVERSIDADE DE SÃO PAULO \\ FACULDADE DE FILOSOFIA, LETRAS E CIÊNCIAS HUMANAS \\ DEPARTAMENTO DE LINGUÍSTICA
}

SAULO NOGUEIRA SCHWARTZMANN

SEMIÓTICA DA COMPOSIÇÃO PICTURAL: O JOGO TENSIVO ENTRE O

FIGURATIVO E O PLÁSTICO NA SÉRIE DAS LIGAS

DE WESLEY DUKE LEE

Versão Corrigida

De acordo Prof. Dr. Ivã Carlos Lopes

São Paulo

2014 


\section{SEMIÓTICA DA COMPOSIÇÃO PICTURAL: O JOGO TENSIVO ENTRE O FIGURATIVO E O PLÁSTICO NA SÉRIE DAS LIGAS \\ DE WESLEY DUKE LEE}

Dissertação apresentada ao Programa de Pós-Graduação em Semiótica e Linguística Geral do Departamento de Linguística da Faculdade de Filosofia, Letras e Ciências humanas da Universidade de São Paulo, para a obtenção do título de Mestre em Linguística.

Área de concentração: Semiótica e Linguística Geral.

Orientador: Prof. Dr. Ivã Carlos Lopes

\section{Versão Corrigida}

De acordo Prof. Dr. Ivã Carlos Lopes

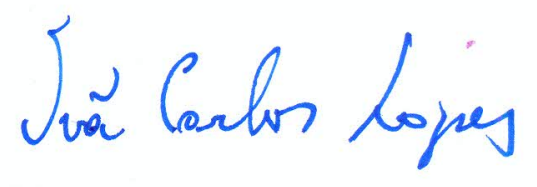

São Paulo

2014 


\title{
SEMIÓTICA DA COMPOSIÇÃO PICTURAL: O JOGO TENSIVO ENTRE O FIGURATIVO E O PLÁSTICO NA SÉRIE DAS LIGAS DE WESLEY DUKE LEE
}

\begin{abstract}
Dissertação apresentada ao Programa de Pós-Graduação em Semiótica e Linguística Geral do Departamento de Linguística da Faculdade de Filosofia, Letras e Ciências humanas da Universidade de São Paulo, para a obtenção do título de Mestre em Linguística.
\end{abstract}

Área de concentração: Semiótica e Linguística Geral.

Orientador: Prof. Dr. Ivã Carlos Lopes

\section{Versão Corrigida}

De acordo Prof. Dr. Ivã Carlos Lopes

São Paulo 
Nome: SCHWARTZMANN, Saulo Nogueira

Título: Semiótica da composição pictural: o jogo tensivo entre o figurativo e o plástico na Série das ligas de Wesley Duke Lee

Dissertação apresentada ao Programa de PósGraduação em Semiótica e Linguística Geral do Departamento de Linguística da Faculdade de Filosofia, Letras e Ciências humanas da Universidade de São Paulo, para a obtenção do título de Mestre em Linguística.

Aprovada em: / 2014.

Banca Examinadora

Prof. Dr. Ivã Carlos Lopes

Instituição: Universidade de São Paulo (USP) Julgamento: Assinatura:

Prof. Dr. Luiz Tatit Instituição: Universidade de São Paulo (USP) Julgamento: Assinatura:

Prof. Dr. Olympio Jose Pinheiro Instituição: Universidade Estadual Paulista (UNESP) Julgamento: Assinatura: 
Para Carolina Tomasi 


\section{Agradecimentos}

Ao meu orientador Prof. Dr. Ivã Carlos Lopes, pelo carinho, amizade e confiança.

Aos amigos que me apoiaram na realização desta dissertação:

Vicente, aquele velho coroco.

Waldir Beividas e lara Rosa Farias, pelo carinho.

Tatit, pelo diálogo.

Beth Harkot, pelas conversas semióticas

Marcos Lopes, pelos assuntos futebolísticos.

Eliane Soares de Lima, pelos encontros musicais.

Érica Flávia e Robinho pela eficiência e paciência.

Thiago, Cleyton, Baule, Akira, Débora, Odair José, Mariana, Danilo e demais amigos da USP.

Olympio Pinheiro, meu primeiro destinador em Duke Lee.

Ao Matheus, meu amigo, meu irmão.

Ao Jeanzito, meu irmão, meu amigo.

A Raquel, Guilherme e família.

Aos amigos-irmãos Segal e David; Du-quase-nada, Bazan, Rico-ricota; Gabriel e sua guitarra (e suas companheiras).

A minha vó Lourdes por tudo.

Ao tio Sérgio, meu padrinho.

Aos meus outros tios e tias.

Ao meu pai Eduardo (Cocó) e Adriana Medina.

A minha mãe Guaraci (in memoriam).

Ao Domingos e a Sueli, que me deram apoio nessa caminhada.

Ao Felipe e Dani, meus novos irmãos.

Ao João Bosco, amigo do peito.

A Dona Rosa, pelo humor ácido.

Ao Paolo Demuru e Julia, pelos momentos superbatutas.

A Day e ao Ricardo, pelos comes e bebes.

Ao Paulinho e Lu, pela amizade.

A minha amada Carolina Tomasi, que me ensinou Saussure a doces chicotadas.

Ao Rosmarininho.

À Faculdade de Filosofia, Letras e Ciências Humanas da Universidade de São Paulo pela oportunidade de realização da Pós-Graduação.

À CAPES, pela bolsa concedida para a realização deste trabalho. 
RESUMO

SCHWARTZMANN, Saulo Nogueira. Semiótica da composição pictural: o jogo tensivo entre o figurativo e o plástico na Série das ligas de Wesley Duke Lee. 2014. 151 f. Dissertação (Mestrado) - Faculdade de Filosofia, Ciências e Letras da Universidade de São Paulo, 2014.

Esta dissertação tem como objeto a Série das ligas, de Wesley Duke Lee, e a examina do ponto de vista da semiótica tensiva. Seu objetivo principal é verificar como se dão as operações no plano da expressão cuja semiótica se apoia nas articulações entre as ocorrências concretas (substâncias) e os sistemas de posições vazias, as estruturas; nesse sistema de estrutura, essas ocorrências assumem valores, ora de esvaziamento, ora de preenchimento. $\mathrm{O}$ jogo entre um e outro ocorre em um contínuo tensivo que oscila entre uma configuração mais plástica e outra mais figurativa, o que nos permite depreender um andamento mais acelerado ou mais desacelerado a depender das escolhas enunciativas. Inicialmente, abordamos a abstração e a figurativização nas artes plásticas, contemplando objetividade e subjetividade. Em seguida tratamos do erotismo, da modalização bem como da enunciação e do programa semiótico do erotismo. Ainda no desenvolvimento ocupamo-nos das escolhas enunciativas de expressão e conteúdo focalizando, inteligível e sensível na pintura e, particularmente, na obra de Duke Lee. Focalizamos também coerções artísticas de estilo e de gênero, assim como os efeitos de linha e cor entre desenho e pintura. Foi ainda objeto de exame a semiose das linhas, em que tratamos de sua tonicidade. Finalmente cuidamos de operações da substância da expressão e de seus efeitos na linguagem plástica. O que nos levou a considerar a relação de contraste e valores bem como a relação sintáxica na Série das ligas. Fecha a dissertação um conjunto de observações, entre as quais se destaca a de que o artista elege elementos expressivos que se orientam de valores mais extensos a mais intensos, sugerindo o alcance da liberdade das coerções miméticas das figuras do universo erótico para atingir operações das substâncias em forma.

Palavras-chave: Semiótica Tensiva. Artes Plásticas. Erotismo. Estética. Pintura. Enunciação. 


\section{ABSTRACT}

SCHWARTZMANN, Saulo Nogueira. Semiotics of the pictorial composition: a tensive play between the figurative and the plastic on Série das ligas of Wesley Duke Lee. 2014. 151 f. Dissertação (Mestrado) - Faculdade de Filosofia, Ciências e Letras da Universidade de São Paulo, 2014.

This dissertation aims Wesley Duke Lee's Série das ligas, examining it from a tensive semiotics point of view. The main goal is to verify how operations occur on expression foreground where semiotics rests on articulations between concrete occurrences (substances) and the hollow systems positions, the structures; on this structure system, this occurrences assume values, either of emptiness or filling. The play between one and other occurs in continuous tensive which varies between a more plastic configuration and a more figurative one, what allows an either more accelerated or more decelerated progress depending on enunciative choices. Initially, abstraction and figurativization on plastic arts were contemplated with objectivity and subjectivity. Hereupon, erotism modalization, enunciation and the semiotic program of erotism were explored. Throughout development, expression enunciative choices and content were focused, aiming the intelligible and the sensitive in painting and, particularly, in Duke Lee's work. Stile and gender artistic coercions were focused, as well as line and color effects among drawings and paintings. Other object of study was the semiosis of lines in which its tonicity was prospected. Finally, the substance of expression operations and its effects on plastic language were explored. That brought contrast and value into consideration as well as the sintaxic relation on Série das ligas. Towards the end, a combination of observations were made, among which we highlight that the artist selects value oriented expressive elements that are more or less extensive, suggesting the freedom of reach of the figure mimetic coercions of the erotic universe, to achieve substance operations in form.

Keywords: Tensive Semiotics. Visual Arts. Eroticism. Aesthetics. Painting. Enunciation. 


\section{RÉSUMÉ}

SCHWARTZMANN, Saulo Nogueira. Sémiotique de la composition picturale: le jeu tensive entre le figuratif et le plastique dans la Série das ligas de Wesley Duke Lee. 2014. $151 \mathrm{f}$. Dissertation (Mestrado) - Faculdade de Filosofia, Letras e Ciências Humanas, Universidade de São Paulo, São Paulo, 2014.

Cette dissertation se concentre sur la Série das ligas de Wesley Duke Lee, en l'examinant du point de vue de la sémiotique tensive. Son but principal est de voir comment les opérations sont donnés en termes de sémiotique dont l'expression s'appuie sur les articulations entre les instances concrètes (substances) et les systèmes de positions vides, les structures; dans un tel système structurel, ces événements prennent des valeurs tour à tour de vidage ou bien de remplissage. Le jeu entre eux se produit sur un continuum tensive qui oscille entre une configuration plus plastique et autre plus figurative, ce qui nous permet d'inférer un tempo plus accéléré ou plus ralenti en fonction des choix énonciatifs. Au départ, nous examinons l'abstraction et la figurativisation en arts plastiques, en contemplant l'objectivité et la subjectivité. Ensuite nous considérons l'érotisme, la modalisation ainsi que l'énonciation et le programme sémiotique de l'érotisme. Nous nous occupons encore des choix énonciatifs d'expression et de contenu, en focalisant sur l'intelligible et le sensible dans la peinture et en particulier dans le travail de Duke Lee. Nous nous concentrons également sur les coerctions artistiques de style et de genre, ainsi que les effets de la ligne et de la couleur entre le dessin et la peinture. La sémiose des lignes a aussi fait l'object de notre examen lorsque nous traitons sa tonicité. Enfin, nous traitons le fonctionnement de la substance de l'expression et ses effets sur le langage plastique. Ça nous a conduit à considérer le rapport de contraste et de valeurs ainsi que le rapport syntaxique dans la Série das ligas. La dissertation ets fermée par un ensemble d'observations, notamment laquelle que l'artiste choisit des éléments expressifs qui sont orientés de valeurs plus extensifs ou plus intenses, ce qui suggère la portée de la liberté des coerctions mimétiques des figures de l'univers érotique à réaliser des opérations des substances sous forme .

Mots-clés: Sémiotique tensive. Arts plastiques. Érotisme. Esthétique. Peinture. Énonciation . 


\section{Sumário}

INTRODUÇÃO, 11

1 ABSTRAÇÃO E FIGURATIVIZAÇÃO NAS ARTES PLÁSTICAS, 15

1.1 Objetividade e subjetividade, 16

1.2 Abstração e figurativização no Brasil, 28

1.3 Nova Figuração Brasileira e o Realismo Mágico, 41

2 O JOGO SEMIÓTICO DO EROTISMO, 53

2.1 Erotismo e tensividade, 54

2.2 Modalização do erotismo: um estudo do léxico, 55

2.3 Programa semiótico do erotismo, 59

2.4 Enunciação e erotismo, 64

3 ESCOLHAS ENUNCIATIVAS DE EXPRESSÃO E DE CONTEÚDO, 75

3.1 Inteligível e sensível em Duke Lee, 76

3.2 Articulação dos meios: o conteúdo da obra de arte, 80

3.3 Coerções artísticas de estilo e de gênero, 83

3.4 Efeitos de linha e de cor: entre desenho e pintura, 92

3.5 Semiose das linhas e das ligas, 94

3.5.1 A linha, 94

3.5.2 A tonicidade das linhas, 97

4 OPERAÇÕES FORMAIS NA SEMIÓTICA DAS LIGAS, 104

4.1 Relação de contraste e valores, 105

4.2 Relação sintáxica da Série das ligas, 111

4.3 Movimento tensivo das ligas, 123

CONCLUSÃO, 126

REFERÊNCIAS, 129

ANEXO - Dez lâminas da Série das ligas, 135

Índice de imagens, 146 
Wesley, para nós aqui, livra a linha de sua própria tradição, e subtrai a origem das belas-artes. As ligas banalizam o arbitrário da rota do traço, parte mágica do desenho. 


\section{INTRODUÇÃO}

Entre as preocupações da história da arte, entendida como parte das ciências humanas, está a de investigar a arte pictórica enquanto linguagem, principalmente com os avanços da linguística moderna. O flerte da arte com a linguística suscita algumas questões. Uma delas tem relação com a "matéria da expressão", que nada mais é do que substância que se endereça a uma forma. Essa preocupação de âmbito hjelmsleviano me levou a pensar nas Ligas de Duke Lee como uma semiótica de articulações entre as ocorrências concretas (substâncias) e os sistemas de posições vazias, as estruturas; nesse sistema de estrutura, essas ocorrências assumem valores, ora de esvaziamento, ora de preenchimento.

Em "Semiótica figurativa e semiótica plástica", Greimas (In: OLIVEIRA, 2004, p. 80), ao tratar da leitura iconizante, afirma que ela é uma semiose, ou seja, uma operação que junta plano de expressão e plano de conteúdo, resultando na produção de signos. Uma leitura semântica requisita que o plano da expressão, "assumindo feixes de traços visuais, de densidade variável", denominados formantes figurativos, proporcione significados, transformando o objeto visual em signos-objeto. Uma observação atenta do ato de semiose nos indicaria que a principal operação que o constitui "é a seleção de certo número de traços visuais e sua globalização". Essa operação faz de um feixe de traços heterogêneos um formante, isto é, uma unidade do plano da expressão, reconhecível quando endereçada ao significado.

$O$ feixe de traços heterogêneos constitutivos do objeto visual levanta a questão da densidade dos traços e de sua organização. Em Duke Lee, verificaremos o interesse do enunciador em eleger a oscilação da densidade maior de traços figurativos, (que culminaria na mimesis do mundo natural) ou a menor densidade de traços figurativos, que culminaria na abstração e na configuração de um objeto plástico. Temos, portanto, em termos semióticos uma oscilação para produzir um simulacro do mundo natural, o artista trabalha dentro de uma medida, que compreende nem insuficiência nem excesso de formantes plásticos. Os extremos 
resultariam na dissolução da figuratividade, isto é, na dominância do plano da expressão sobre o plano do conteúdo. Produzindo um simulacro do mundo natural, haveria maior extensidade e menor aceleração sensível; se desinteressar-se pela reprodução do mundo natural, sua realização pode levar à falta de reconhecimento do objeto, dando lugar à intensidade e à aceleração sensível. Todavia, o artista pode sincreticamente ocupar-se da oscilação entre reprodução do mundo natural e não reprodução do mundo natural. Esse jogo tensivo é o que chamamos, nesta dissertação, de semiótica da composição pictural, que transita entre um erotismo figurativo e um erotismo plástico. Utilizamos aqui o termo plástico não no sentido wolffliniano que o identifica com o estilo linear, delineado (WÖLFFLIN, 2006, p. 2529), marcado pela discriminação visual plástica, estabelecendo contornos nítidos e firmes. Utilizamo-lo, porém, no sentido da acepção 4 do Dicionário Houaiss: "belo quanto à forma, ao aspecto; pictórico" (HOUAISS; VILLAR, 2001). Ora, é justamente o aspecto pictórico que identificamos com o plástico nas telas de Wesley Duke Lee.

Compõe este trabalho um corpus de dez lâminas ou telas que constituem a Série das ligas, de Wesley Duke Lee ${ }^{1}$. Optamos por uma análise semiótica do conjunto das telas, que vai das mais figurativas às mais plásticas (figurativo em termos de maior simulação do mundo natural e plástico em termos de menor simulação), e não propriamente por uma análise de cada uma das telas. As dez telas compõem uma unidade, uma série, ou seja, uma rede organizada de relações hierárquicas. O número significativo de telas plásticas, menos figurativas, indica um enunciador mais preocupado com o processo do fazer artístico do que com a representação do mundo.

Nossa investigação procura evidenciar os efeitos de sentido constituídos pelo plano da expressão das linhas e das cores. Por isso, dedicamo-nos neste trabalho ao exame das operações formais realizadas sobre a substância da expressão na linguagem plástica e de seus efeitos de sentido.

\footnotetext{
${ }^{1}$ Wesley Duke Lee, artista plástico brasileiro, nasceu em São Paulo em 1931 e durante o período de 1948-1952 já trabalhava com arquitetura e possuía um atelier onde fazia várias experiências com soldas, metais, plásticos. Cursou desenho no Museu de Arte Moderna e, a seguir, foi estudar tipografia e publicidade nos EUA, tendo contato com obras que marcaram profundas transformações do curso das artes em Nova lorque e, posteriormente, na Europa; Lee pôde estar em sintonia com as inovações e criatividade da arte internacional. Na década de 60 , de volta ao Brasil, foi pioneiro em diversas linguagens artísticas como o happening e as instalações. Seu posicionamento sempre foi a favor de uma expressão poética desligada de militâncias políticas e ideológicas e de uma expressão sempre carregada de sarcasmo, irreverência e erotismo. Destaca-se a sua importância na atuação como líder para os fundadores da Escola Brasil e demais artistas de sua geração.
} 
Trataremos ainda da figurativização das ligas que, por serem fragmentadas e revelarem apenas partes do corpo feminino, convocam o enunciatário a preencher ou a esvaziar o objeto, constituindo assim um sentido de erotismo de diferente ordem: mais plástico ou mais figurativo. O objeto artístico, tal qual o objeto da ordem do erotismo, é, como teremos oportunidade de explanar adiante, mediador do prazer. Prazer que se orienta em duas direções, uma de ordem extensiva, em que se pode reconhecer uma figura feminina nua, e outra de ordem intensiva, em que se notam valores plásticos e estéticos.

Por isso, focalizaremos o andamento das Ligas como objeto erótico. O processo metonímico resulta na escolha de linhas que se interrompem, produzindo um efeito de elipse que implica maior aceleração. Se a linha é contínua e a apresentação do objeto ganha características miméticas, desacelera-se o andamento, atonizando o sensível, num processo que desemboca numa aceleração da apreensão inteligível.

A disposição das telas referentes à série que compõe o corpus deste trabalho não segue a cronologia de produção das obras. Dispusemo-las numa ordem que nos interessava para a argumentação desta dissertação: disposição que vai de telas mais miméticas a menos miméticas, embora reconheçamos que a preocupação fundamental das artes plásticas contemporâneas não é representar o mundo natural, mas tornar visível o que não é visível.

Também serão discutidas questões referentes aos efeitos de objetividade e/ou subjetividade provocados na enunciação. As escolhas enunciativas de um artista quando decide pelo efeito de desenho ou pelo efeito de pintura, de acordo com os materiais de expressão empregados na sua ação (tinta a óleo, aquarela ou guache, por exemplo), determinam características e atributos, tais como durabilidade e temporalidade. A temporalidade está associada à tensão espacial, já que seu conceito assegura a continuidade ou ruptura dos formantes plásticos.

A complexidade espacial abrange também os limites externos do formato da tela, que possibilita criar movimentos visuais ordenados. Por isso, antes de escolher a ação do pincel, espátula ou até mesmo golpes de tintas, o enunciador faz, em outro registro, escolhas de ordem tensiva, selecionando valores dinâmicos de aceleração e desaceleração, de esvaziamento e/ou de preenchimento, cada um deles de acordo com as exigências e coerções dos materiais à sua disposição. 
Para Zilberberg (2006, p. 132-133), a temporalidade pode ser expectante ou originante. Se expectante, o espaço é esvaziado e a sintaxe quer preencher o vazio; se originante, o espaço é preenchido, solicitando esvaziamento, e assim por diante. Outra característica das peças sob análise é que seu esvaziamento advém sobretudo de um processo tensivo desse fazer artístico: na maioria das telas, vemos tão somente pedaços de corpos, fragmentos de peças íntimas que pedem recomposição, requerendo maior participação do enunciatário.

É, pois, com base nesse jogo tensivo entre esvaziamento e preenchimento que o enunciador convoca um erotismo mais da ordem da intensidade ou mais da ordem da extensidade. De acordo com suas escolhas, as possibilidades de participação do enunciatário podem ser mais ou menos reduzidas; quando essa participação é reduzida, o efeito de sentido é de distanciamento ou objetividade (extensidade); se a participação do enunciatário for intensificada, o efeito de sentido é de subjetividade (intensidade). Nos enunciados plásticos das obras da Série das ligas, podemos pressupor que as escolhas tanto do plano da expressão quanto do plano do conteúdo são orientadas por um destinador que valoriza mais os arranjos plásticos que os figurativos. Para Greimas e Courtés (2008, p. 132), o destinador comunica ao destinatário sujeito, ambos imanentes, não apenas competência modal, mas também um conjunto de valores em jogo. No caso de Duke Lee, esse destinador é constituído por seus pares e/ou críticos de arte, entre outros, como veremos nesta dissertação.

Ao convocar o enunciatário, o enunciador da Série das ligas preza pela economia dos traços, pela metonímia constante que leva à concentração, a uma intensidade alta. Esses efeitos de objetividade e subjetividade são produtos da enunciação; tratando-se de discurso verbal, a subjetividade é constituída por pronomes pessoal, possessivo, adjetivos, advérbios e formas verbais. A objetividade, por seu lado, é produto da ausência dessas marcas. Já na pintura, como exemplificaremos adiante, o efeito de objetividade é produzido pela precisão das linhas e dos contornos, ou seja, as linhas iniciam e terminam um percurso sem interrupção.

O efeito de subjetividade na pintura, por sua vez, pode ser produzido, além de outros recursos, pela interrupção das linhas, ausência de contornos definidos; esses elementos, por estarem diluídos na composição, requisitam a cooperação do enunciatário para preencher a figura sugerida. 
Finalmente, pretendemos investigar como os traços plásticos constituem "sílabas", regidas pelo mesmo princípio de abertura e fechamento. Nesse caso, como veremos, o volume constituiria a abertura, a vogal, e a linha constituiria o fechamento, a consoante. Uma densidade maior de consoantes (rupturas) produz um objeto mais intenso, mais plástico e que se afasta da mimese figurativa, esta última formada pela regularidade de abertura e fechamento. 
O cubismo é uma palavra inventada pelos críticos, mas nós nunca fomos cubistas.

Braque

Não é bem assim. Nós vivemos num certo momento essa procura, mas, ao afastarmo-nos dela, apercebemo-nos de que éramos, acima de tudo, indivíduos.

Picasso

\subsection{Objetividade e subjetividade}

$\mathrm{Na}$ história das artes plásticas, sempre houve uma oscilação entre objetividade e subjetividade; no entanto, há uma dominância desta última na contemporaneidade. A objetividade dependia de certos "cânones" mediados pelos mais diversos destinadores (Igreja, mecenato, burguesia, academias, escola de Belas Artes, ou até grupos menores como Futurismo e Cubismo, só para citar alguns exemplos), sendo primordial para a construção de uma nova realidade. Assim é que na base de um cânone de um movimento artístico houve primordialmente uma interferência subjetiva; o Cubismo, por exemplo, antes de constituir-se em um cânone objetivo com determinadas regras de constituição do sentido, foi determinado por uma escolha que não se conformava com os valores anteriores. Daí a ruptura. Podemos ver nos discursos de Picasso e de Braque epigrafados discussões sobre os cânones que se firmaram diante de suas obras, mesmo que através de uma primeira iniciativa subjetiva.

No decurso das produções artísticas, portanto, o que era um valor individual passa a ser, em seguida, um valor de grupo, a constituir-se em novo destinador das artes. De qualquer forma, não podemos dar maior valor à subjetividade ou à objetividade. Tanto uma quanto a outra são particularidades que merecem relativa importância na produção de sentido em um enunciado plástico. Ademais, mesmo um enunciador que opta por escolhas da ordem mais objetiva na construção pictural não deixa de estar isento de sua subjetividade, nem de convidar o enunciatário a desenvolver o sentido que pode ser obtido na observação de suas obras.

Os estudos da percepção das formas desenvolvidos, que pela ULM, quer pela Bauhaus, advindos da psicologia da Gestalt, por exemplo, tratam a subjetividade e a 
objetividade nas artes, resumida e simplificadamente, de duas maneiras: os elementos da gramática visual objetivos são o ponto, a linha, a forma, o plano e a cor; os elementos da gramática visual subjetivos são: o equilíbrio, a simetria, a harmonia, o peso, apenas para citarmos alguns desses elementos. Ou seja, de qualquer maneira, a enunciação artística sempre pressupõe uma subjetividade, mesmo que mínima, na coparticipação de seus atores pressupostos (enunciador/ enunciatário).

Para a semiótica, o caráter subjetivo ou objetivo de uma obra plástica pode ser verificado também pelas escolhas dos seus enunciadores. O efeito de sentido objetivo ou subjetivo na Série das ligas também pode ser avaliado quando se colocam em contraposição duas ou mais telas. Podemos então verificar certa gradação de mais ou menos objetividade (maior ou menor simulação do mundo natural), justamente pelas características das linhas e do contorno dos objetos.

Portanto, o efeito de sentido subjetivo ou objetivo é estabelecido no próprio discurso, quer por meio de uma enunciação que se distancia do seu objeto, quer por meio de uma enunciação que dele se aproxima. Se o artista escolhe valores de proximidade com o enunciatário, orientará a constituição dos enunciados plásticos pela intensidade das cores, dos traços, dimensão e inacabamento das formas. $\mathrm{Na}$ constituição objetivista, as características plásticas não ganham relevo, não ganham intensidade; as formas são concluídas, não há muita possibilidade de participação do enunciatário, ou, pelo menos a participação é menos intensa. Vejamos, nas figuras $1.1,1.2$, um exemplo de efeito de sentido de objetividade e na figura $1.3 \mathrm{um}$ exemplo de subjetividade: 
Figura 1.1
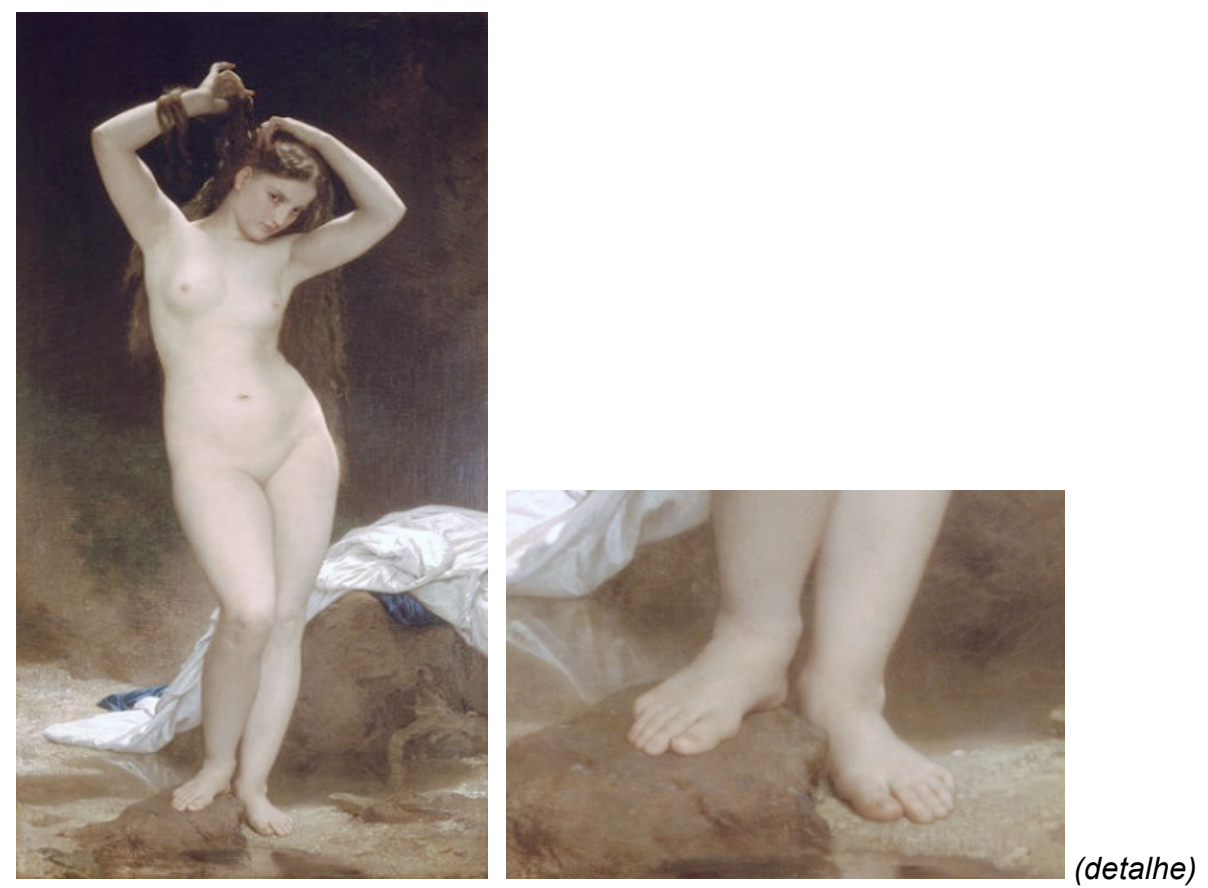

Banho

(William Bouguereau, 1870, óleo s/tela, 190.5 x 95 cm)

Figura 1.2

(representação canônica do Classicismo)

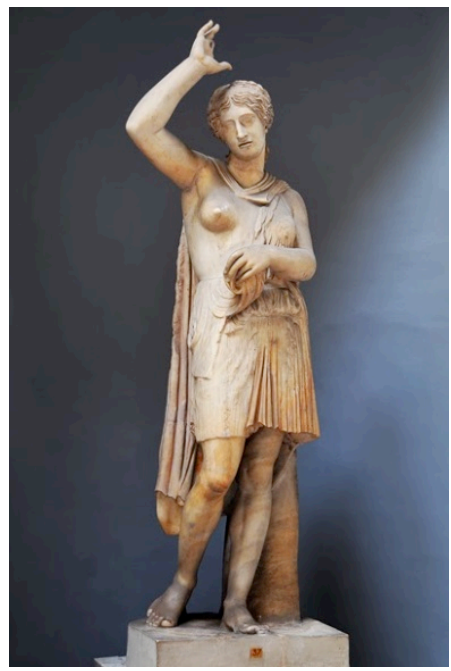

Amazona Ferida (tipo Sosicles), cópia romana segundo um original grego de bronze de Policleto, do séc. V a.C. (c. 440-430 a.C.). Mármore. 
Figura 1.3

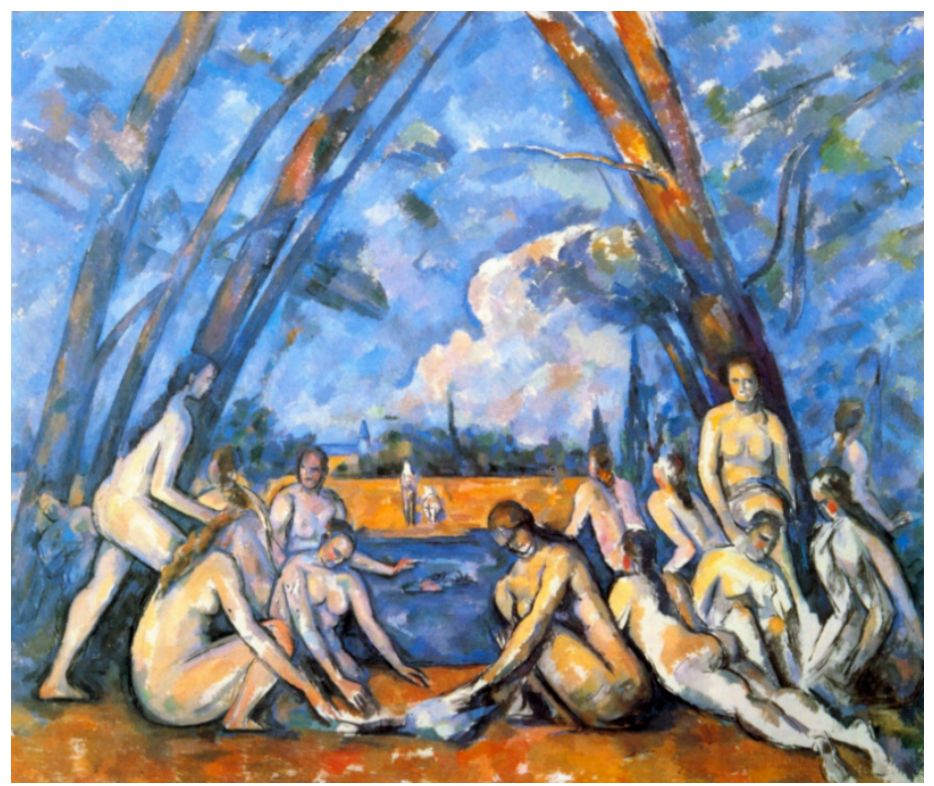

As grandes banhistas

(Cézanne, 1898-1900, óleo s/tela, 208 x 249 cm)

Detalhes
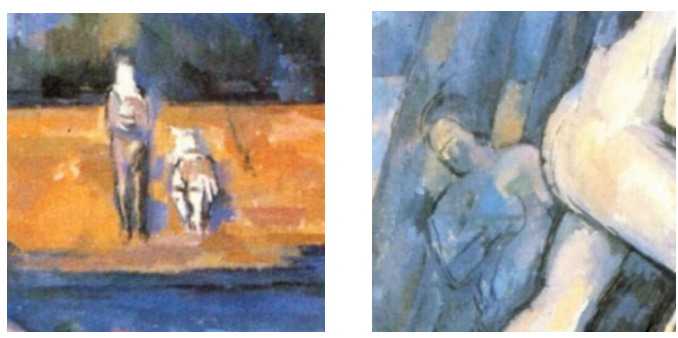

Em Bouguereau, temos o efeito de sentido de objetividade mais acentuado; não há muitas marcas explícitas do enunciador no enunciado. $O$ enunciador, porém, se revela discretamente nas escolhas de enquadramento, luminosidade dos corpos pintados, etc. A intervenção do enunciador da pintura é constitutiva: está sempre lá. O que pode variar é que ele pode optar por mostrar-se menos ou mais. O efeito de objetividade também pode ser visto nas obras renascentistas, bem como no classicismo greco-romano e no neoclassicismo.

A constituição da objetividade em Bouguereau pode ser atribuída ao mecanismo da fotografia, que o artista utilizou na produção de simulacros do mundo natural. Ao olharmos as mulheres que Bouguereau pinta, percebemos elementos que identificamos com maior grau de "verossimilhança" com a anatomia do corpo humano (detalhe dos pés). Vemos também que o artista é partidário de cânones estabelecidos pelas Academias (ver na figura 1.2 o exemplo de representação 
canônica do corpo humano), ou seja, de representação do corpo segundo proporções e simetrias na composição que denunciam suas escolhas mais objetivas: proporção entre o braço e antebraço, as pernas e quadril seguindo o perfil grego, com uma das pernas ligeiramente para a frente e um dos joelhos dobrado, cor da pele, em suma, alguns dos ideais canônicos de beleza resgatados do Classicismo, como ocorreu durante boa parte do século XIX (Neoclassicismo). Não deixamos de observar que, em suas escolhas plásticas, estão presentes valores de representação do corpo humano que evidenciam detalhes que facilitam a identificação das figuras representadas como figuras de corpo humano.

Se compararmos a tela erótica de Bouguereau com as lâminas da Série das ligas de Duke Lee, verificaremos que, enquanto o primeiro engendra um efeito de sentido mais objetivo, o segundo produz uma intensidade mais subjetiva na composição erótica. A propósito, cito Gombrich (1999, p. 37) em relação ao erotismo de Bouguereau:

Trata-se muito mais de uma moça de calendário do que de uma obra de arte. Queremos dizer com isso que o apelo erótico está à superfície - não é compensado por esse compartilhamento no processo imaginativo do artista. A imagem é dolorosamente fácil de ler, e nos indignamos por ser tomados por semelhantes simplórios. Sentimo-nos um pouco insultados por esperar que caiamos nesse chamariz barato.

Nesse trecho de Meditações sobre um Cavalinho de pau, o historiador defende, portanto, que, naquele instante da arte (século XIX), principalmente na França, o que era aceitável como arte seria aquela em que acontece "o jogo sofisticado de criar uma aparência intencionalmente dessemelhante". Tais afirmações estão em desacordo com o que alguns artistas defendiam sobre a concepção de beleza herdada dos gregos.

Contudo, o que pretendemos mostrar aqui não é o juízo de valor a respeito de uma obra de arte ser ou não ser arte, ou sobre o gosto peculiar dos "eruditos" ou dos "simplórios". Interessa-nos apenas salientar a diferença entre um erotismo explícito, como o é o de Bouguereau, e um erotismo menos explícito, como o é o de Duke Lee.

O enunciatário da obra de Bouguereau participa menos na produção de sentido de erotismo e, portanto, temos aí uma obra mais objetiva. Parece-nos que o enunciador não acredita nas potencialidades sensíveis do enunciatário e prefere dar 
de antemão os mínimos detalhes para a fruição do seu enunciado plástico. Não negamos a existência do erotismo em Bouguereau. Sua imagem é erótica e lida com elementos expressivos que reavivam o prazer no enunciatário. No entanto, as coisas estão lá postas de forma distanciada para o deleite visual, exigindo pouca participação do enunciatário.

Já em Cézanne (figura 1.3), a forma da figurativização indicia uma participação maior do enunciador no enunciado (tanto quanto do enunciatário), ou seja, evidencia as marcas de um enunciador no registro de sua prática. A começar pelas escolhas das cores, podemos verificar um efeito de sentido pelo escurecimento ou clareamento dos tons sem que haja o preto (sombra). $O$ artista questiona dessa forma o mimetismo da representação, pois é o enunciatário competente que vê a cor pelo contraste sensível que ela produz. É por isso que vemos o azul, quase violeta, em contraponto com o alaranjado, por exemplo, criando os volumes pela relação tonal entre essas cores. Segundo essa teoria, um tom "ausente" na paleta é obtido na tela pela aproximação de outros dois. No impressionismo, no neoimpressionismo, no divisionismo e no pós-impressionismo, essas relações cromáticas faziam parte da composição e harmonização entre as cores. São construções altamente subjetivas, apesar da "capa cientificista" pretendida pelo "cientista-pintor".

Por isso, as figuras discursivas que sugerem corpos de mulheres nuas tomando banho são coloridas por módulos de cores que não se assemelham às cores de um corpo feminino nu (confundem-se com as cores utilizadas para criar o céu, a cor da pele, o tronco das árvores). Além disso, na obra de Cézanne, quanto à configuração dos corpos, vemos que as figuras não são compostas a partir de regras de proporção baseadas no exame do corpo humano. Em tudo o que vemos em Cézanne, notamos não a preocupação em produzir um efeito de sentido objetivo, mas uma preocupação em mostrar uma subjetividade do mundo natural.

Anteriormente, para traduzir mimeticamente a figura do corpo humano, alguns artistas o faziam incorporando no desenho as medidas de um corpo e a natureza de sua forma anatômica. Buscavam com precisão empírica verificar as medidas dos membros do corpo humano. Essa precisão matemática constitui os cânones de beleza vigentes no Classicismo, na Renascença e no Neoclassicismo. Artistas renascentistas, por exemplo, tinham a concepção de que a representação perfeita estaria de acordo com a maneira de expressar sinais físicos e emocionais, e 
acrescentar a beleza. Nesse aspecto, a beleza era um conjunto de fatores que estavam relacionados ao termo estético propriamente.

Em Cézanne, são outros os cânones destinadores de sua arte. Na sua obra, ao contrário da imagem de Bouguereau em que podemos até contar os dedos das mãos e dos pés, as figuras das mãos são apenas sugeridas por algumas formas e linhas. Além disso, basta observarmos em As banhistas como o artista representa o que seriam duas pessoas se banhando na outra margem do rio (topologicamente, as duas figuras se encontram quase na porção central do quadro).

O que podemos ver pintado são apenas manchas que sugerem figuras do corpo humano simplificadas. O que vale aí não é mais a pragmática formal e estética que implicava princípios matemáticos de proporção e harmonia (estética = beleza). São pinturas que mais sugerem do que buscam verossimilhança. Nas suas representações plásticas, criam o efeito de sentido de mais subjetividade, pois exigem que o enunciatário participe da obra, que ele a complete. 0 contrato entre o enunciador e o enunciatário, nesses casos, é de participação maior. O prazer em "ajudar" a dar sentido à obra de arte está atrelado ao fruir estético. Falaremos mais adiante sobre a fruição e os efeitos de sentido que o erotismo suscita nos enunciatários.

Em Duke Lee, na Série das ligas, há tanto o efeito de sentido de objetividade como o de subjetividade sem, no entanto, estabelecer discretizações, ou seja, tanto a subjetividade quanto a objetividade são configuradas em termos graduais. Assim é que na figura 1.4 há uma tendência maior pela objetividade:

Figura 1.4

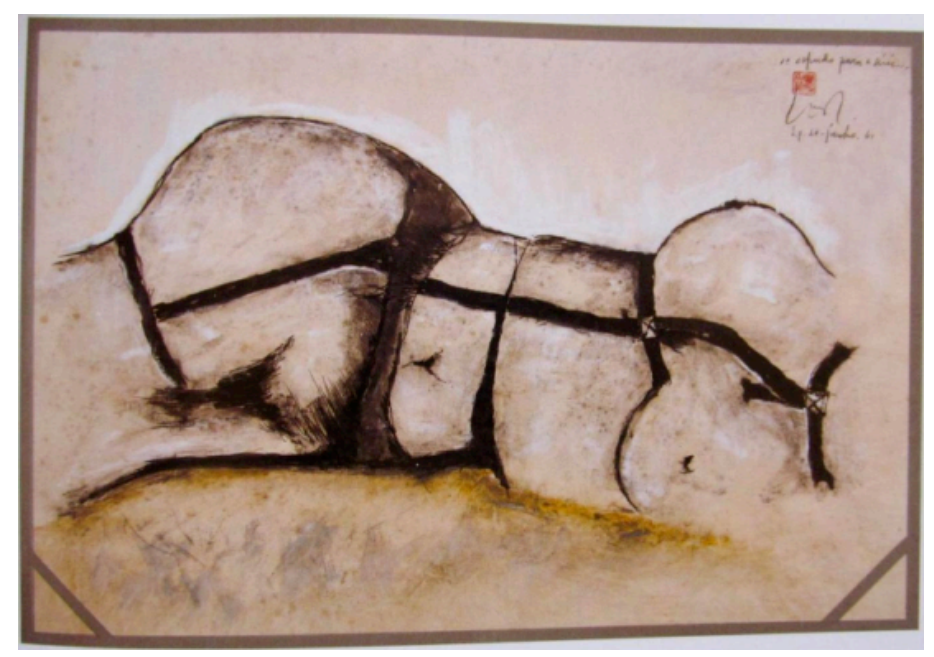

Primeiro estudo para a série...

(Wesley Duke Lee, 1961, nanquim e guache s/papel, 41 x $61 \mathrm{~cm}$ ) 
Já na figura 1.5, vemos que o enunciador optou por uma subjetividade mais mostrada:

Figura 1.5

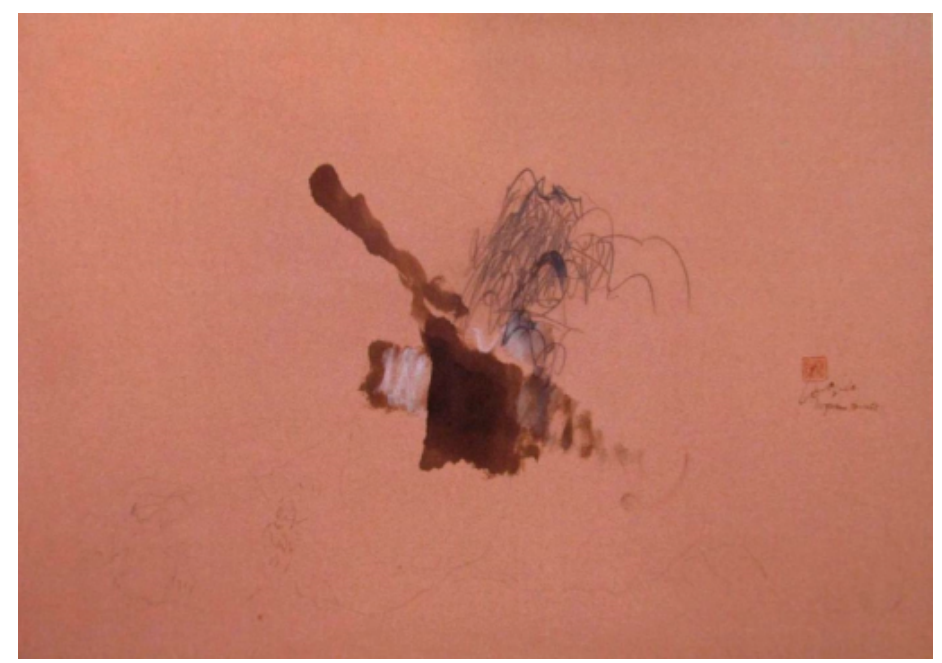

Série das ligas

(Wesley Duke Lee, 1962, betume e grafite s/ papel colorido, 48 x $67 \mathrm{~cm}$ )

Nas duas telas vistas, não há interesse por uma figurativização plena de um corpo feminino. No entanto, a primeira, mais objetiva, é construída com elementos que recortam a forma do que seria, figurativamente, reconhecível como o corpo de uma mulher seminua, utilizando peças íntimas (ligas), sem que os membros (braços, pernas) sejam representados. Nesse caso, existe também uma subjetividade, visto que a pintura já é de certa forma subjetivizada pelo enunciador.

A "cor da pele" é a mesma que a do fundo e a mesma do espaço ao redor da figura feminina pintada. Por isso, o que atestamos aqui são graus de objetividade e subjetividade dessa ou daquela prancha de Duke Lee, em confronto com elas mesmas, para aferirmos tais graus de maior ou menor subjetividade/objetividade. Portanto, na figura 1.4, ainda que haja a representação parcial de um corpo humano, conseguimos, mesmo sem o auxílio dos títulos, identificá-lo como um corpo feminino, pois existe um mínimo de formantes plásticos que sugerem a forma de um seio, dos quadris, do púbis, do umbigo etc.

Ao examinar uma imagem, Barthes (1984, p. 31-34) propõe duas relações possíveis entre a semiótica verbal e a plástica. Como toda imagem é polissêmica e a 
semiótica verbal tende a reduzir a polissemia da semiótica plástica, Barthes entende que podemos ter uma função de ancoragem ou uma função de etapa verbal ${ }^{2}$.

No caso da Série das ligas, as legendas sob as figuras têm função de ancoragem, pois dão uma orientação ao sentido do enunciado pictórico. É possível, porém, que o artista componha sua tela com figuras e palavras (ilustração 1.1), como podemos ver no próprio Duke Lee:

\section{Ilustração 1.1}

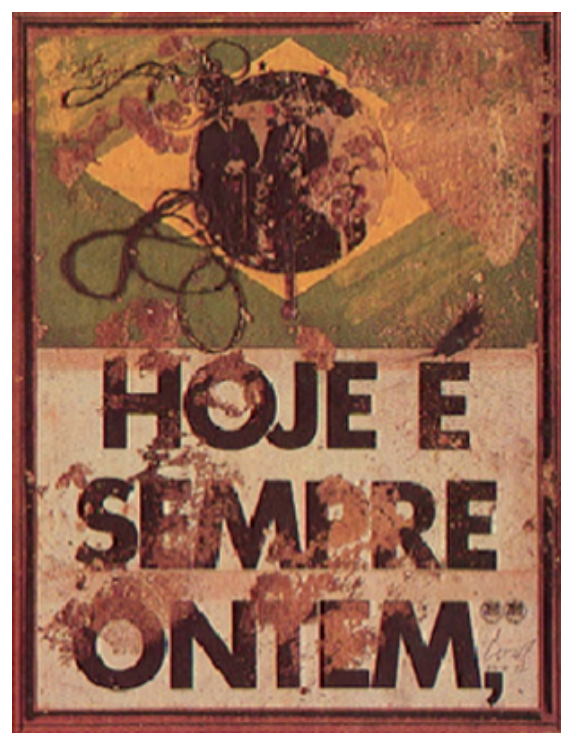

Hoje é sempre ontem - série Origens da Formação de um Povo IV

(Wesley Duke Lee, 1964-1972, carvão e colagem de linha, paetês e folha de ouro s/papel, 30,5 x 23,9 cm)

Nesse caso, a semiótica verbal faz parte do próprio quadro, tratando-se de uma semiótica sincrética. As palavras que aí vemos têm uma função, segundo Barthes, de etapa verbal, já que os signos verbais compõem o enunciado plástico, ajudando a dar sentido ao texto pictural. Diferentemente, nas pranchas da Série das ligas o texto verbal que aparece em algumas lâminas faz parte do que Barthes chama de ancoragem, visto que serve apenas para direcionar o sentido. Poderia haver nesse caso possibilidade de mais de uma leitura, mas o enunciador restringe a polissemia do enunciado por meio do texto que acrescenta à tela.

\footnotetext{
${ }^{2}$ Roland Barthes (1984, p. 32) afirma que a ancoragem tem "uma função de elucidação": nesse caso "o texto dirige o leitor entre os significados da imagem, faz-lhe evitar uns e receber outros". A função de ancoragem é encontrada, sobretudo, na fotografia veiculada na imprensa e na publicidade; ela serve de controle, ela "detém uma responsabilidade, face ao poder projetivo das figuras, sobre o uso da mensagem; em relação à liberdade dos significados da imagem, o texto tem um valor repressivo, e compreende-se que seja ao seu nível que se investem, sobretudo, a moral e a ideologia de uma sociedade". Já a função de etapa, Barthes afirma ser mais rara; é encontrada particularmente em desenhos humorísticos e HQs. Nesta função a palavra e a imagem estão em relação complementar; "as palavras são então fragmentos de um sintagma mais geral, tal como as imagens, e a unidade da mensagem faz-se a um nível superior: o da história, da anedota, da diegese".
} 
Em relação à figura 1.5, o efeito de sentido é de maior subjetividade, comparado à figura 1.4, que, por sua vez, produz um efeito de sentido de objetividade. Além disso. a figura 1.5 mostra um esvaziamento semântico, já que nem mesmo os formantes plásticos mínimos trazem à tona formas e figuras que, sem nenhum tipo de ancoragem, propiciem ao enunciatário compreender que se trata de um corpo humano feminino vestido parcialmente por ligas.

Esse jogo de "tentar descobrir" é uma artimanha que garante a participação do enunciatário competente, juntamente com o título. Se, ao contrário, o título fosse algo relacionado à cartografia, poderíamos procurar ver nos formantes plásticos algo que se assemelhasse aos relevos de um morro, planície etc. Não afirmamos que uma paisagem não possa despertar interesse do enunciatário, mas, quando ela convoca a participação do enunciatário, há um sentido estético tônico. Duke Lee parece brincar com esse jogo estético muito bem, como podemos ver na figura 1.6.

Figura 1.6

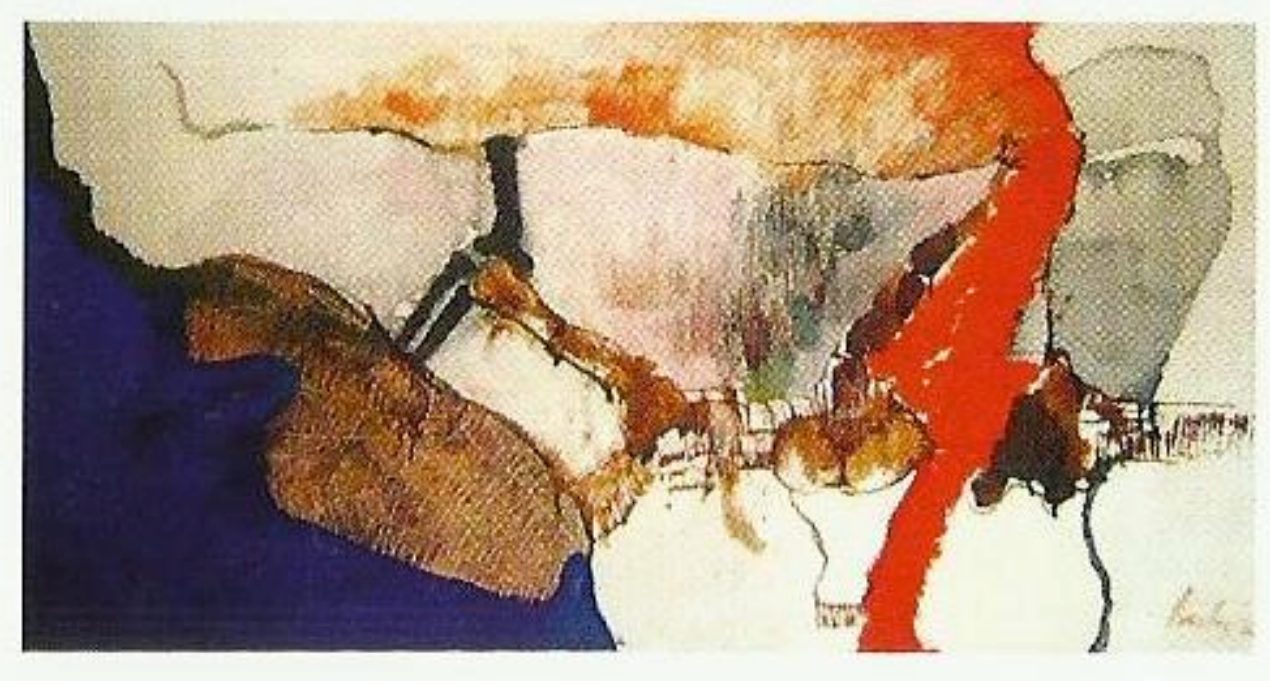

A praia

(Wesley Duke Lee, 1963, têmpera s/ tela, 50x100cm)

Do mesmo modo, caso o título da figura 1.6 fosse relacionado com um tema erótico, haveria uma busca por elementos expressivos que pudessem tornar nítidos os relevos de uma figura feminina nua, por exemplo; no entanto, ele diz ser praia, revelando um "parecer imperfeito" de praia. Como ficaria a nostalgia da perfeição de que nos fala Greimas em Da imperfeição? Ela ficaria do lado do sujeito que procura, na praia de Duke Lee, novamente a conjunção com ligas. 
Temos afirmado que, quanto maior a subjetividade do enunciado, maior convite à participação do enunciatário. É isso, portanto, que torna mais intenso o efeito de sentido estético, pois ele instiga a "participação", o que tornaria o sensível mais intenso. E, por outro lado, quanto maior é o reconhecimento das formas como figuras discursivas redundantes do corpo feminino, menor é a participação do enunciatário e, portanto, o efeito de sentido estético seria de menor intensidade.

Teremos oportunidade de esclarecer que poderia haver, na pintura, uma homologação entre o efeito puramente plástico e um tipo de erotismo mais intenso. Quanto maior a intensidade do prazer sensível (estético), mais intenso é o erotismo.

Duke Lee atrela ao seu processo de criação diversas técnicas e estratégias que criam efeitos de sentido diferentes, de acordo com a sua combinação de elementos, sejam eles elementos da ordem da substância, como tinta, grafite, colagem, sejam ainda elementos que recompõem "figuras" de conteúdo.

Uma pessoa diante de um padrão formal de pintura ou de desenho, articulado a um tema, poderá entender como significativos para a obra de arte tanto os aspectos figurativos quanto os não figurativos. Dessa forma, há nas artes plásticas uma continuidade entre a arte "figurativa tradicional" e a "abstrata", não mimética. Seria um engano entender que apenas a obra não figurativa é abstrata, pois também aquela que é figurativa conta com certa abstração. Por sua vez, a arte abstrata também conta com uma figurativização. Passando ao largo da discussão entre concreção e não abstração, os quadrados constantes de várias obras de Piet Mondrian também são figuras discursivas; em termos semióticos, qualquer figura discursiva produz algum efeito de sentido a depender das relações.

Para o leigo, no entanto, de modo geral, sua pintura parece mais abstrata que a de um Rafael. A diferença é que Rafael pinta corpos e Mondrian pinta quadrados, formas geométricas. Sob as figuras de um e de outro há temas. A arte abstrata não nega a existência de figuras, nem é predominantemente temática. A título de exemplo, vejamos uma obra de Mondrian (figura 1.7): 
Figura 1.7

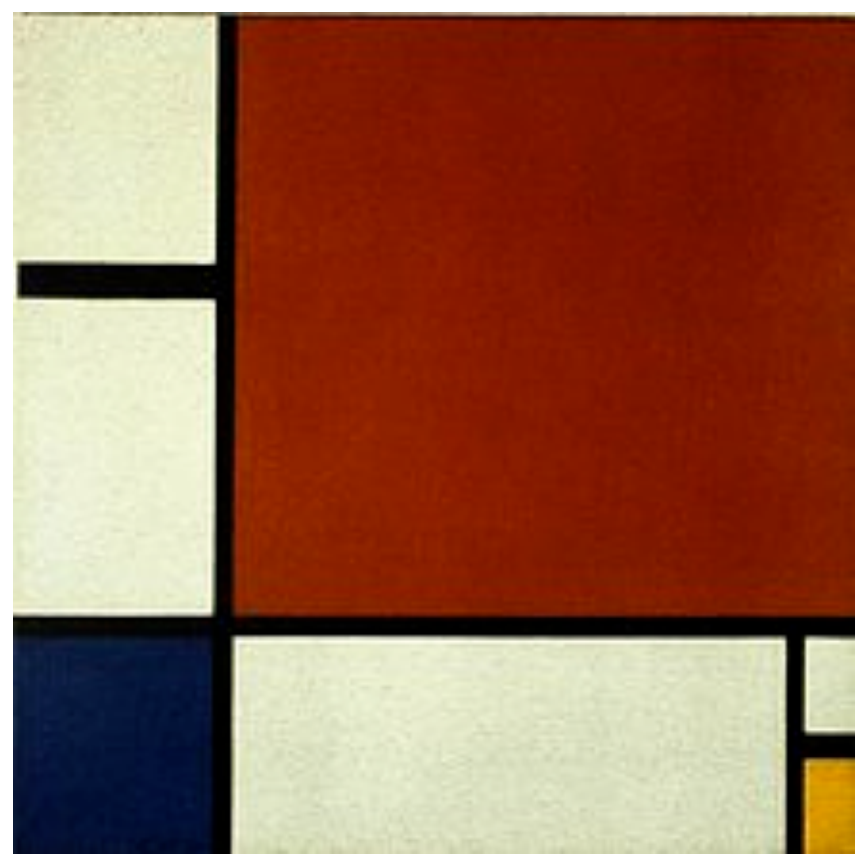

Composição Il em vermelho, azul e amarelo

(Pieter Cornelis Mondrian,1930, óleo s/tela, 86 x 66 cm)

Na obra de Duke Lee que estamos examinando, as ligas ou fragmentos delas, os corpos ou suas partes, são para a semiótica figuras, sob as quais há um tema. As artes plásticas, como afirma Arnheim (1986), sejam miméticas, sejam não miméticas, em sua maneira própria, fazem o que sempre fizeram, às vezes enfatizando figuras que simulam o mundo natural, às vezes enfatizando determinados temas. Se Rafael, por exemplo, enfatiza mais figuras do mundo natural, Mondrian, por seu lado se volta mais para os elementos da própria arte, como relações de formas e cores. Portanto, as catalogações visam apenas classificar artistas, distribuindo-os em grupos que talvez ajudem o enunciatário a entender suas obras em um contexto ou outro.

O que determina o caráter abstrato ou não de uma obra, geralmente, é a maneira como os elementos composicionais tanto do plano da expressão quanto do plano do conteúdo são arranjados. Suponhamos um artista qualquer que utilize linhas retas, compondo um objeto talvez não encontrável no mundo natural. Nesse caso, temos uma pintura que tende para o abstrato, como podemos ver no desenho a seguir, à esquerda. Já no desenho à direta, temos a mesma quantidade de formantes (linhas) arranjados de uma forma que tende mais para o figurativo, já que pode ser reconhecível como uma cadeira. 

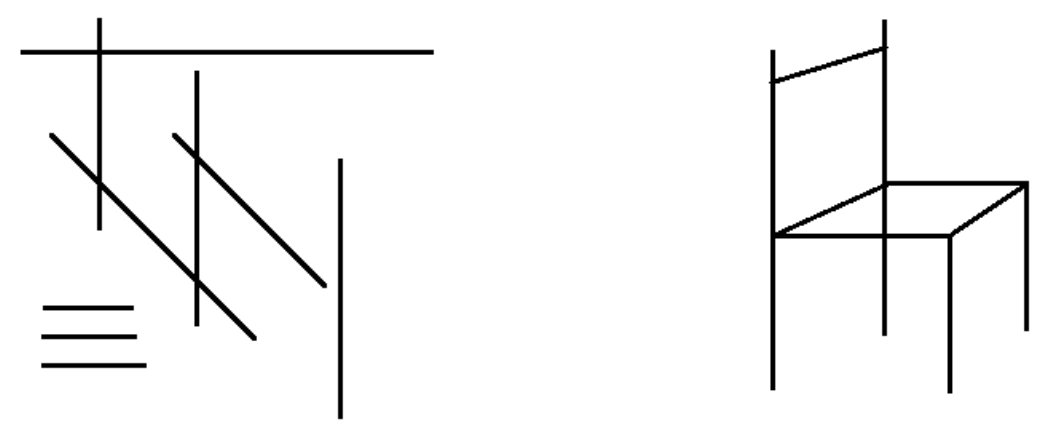

Em Duke Lee, parece importante atentar para esses limites e limiares entre o figurativo e o abstrato, para definirmos o grau de figuratividade ou o grau de abstração das suas "odes eróticas" que podem revelar-nos um tipo de erotismo ou outro que esteja relacionado diretamente a estas configurações plásticas: há um erotismo mais plástico, bem como um erotismo mais mimético.

É por isso que, já que nas pranchas da Série das ligas podemos encontrar ambas as características, ora mais ora menos acentuadas, não poderíamos situar Duke Lee como artista abstrato, ou como artista figurativo. Além disso, nas lâminas em que predominam elementos com menor grau de verossimilhança com o mundo natural, a função de ancoragem desempenhada pelo verbal orienta a constituição do sentido.

São as escolhas de cada enunciador que conversam com determinadas características nas quais podemos identificar um grupo de caracteres distintos que, nos enunciados plásticos, conduzem seu enunciado mais para um efeito de sentido plástico ou mais ou menos mimético. Determinadas obras fazem parte de um movimento por semelhanças de traços, temas ou figuras e, no caso da Série das ligas, temos também os efeitos de sentido erótico que contribuem para seu agrupamento enquanto série.

\subsection{Abstração e figurativização no Brasil}

O projeto vanguardista brasileiro procurou sua identidade observando os problemas que a arte moderna evocou sobre aspectos do plano do conteúdo (temas) e aspectos do plano da expressão. Couto (2004, p. 20) afirma que:

em alguns momentos sucumbindo ao prestígio ideológico dos países que nos serviam de modelo, importávamos, sem maiores questionamentos, modas, estilos e convenções artísticas; em outros, 
ao contrário, rejeitávamos o contato com o estrangeiro, considerando prejudicial toda e qualquer influência externa.

Na modernidade, o surgimento de novas propostas levou os artistas nacionais a pensar nos problemas da arte como tal, sugerindo novos métodos de pesquisa e novas técnicas. O que ocorreu com o "realismo" após a arte não figurativa, em suas novas formas de representação, como a Pop arte norte-americana e o Novo Realismo francês, fez surgir uma problemática artística que não pode ser abordada com o mesmo instrumental crítico que serviu para a abordagem do figurativismo anterior. Esse novo figurativismo também possibilitou aos artistas experimentações no âmbito da semiótica verbal. A introdução de títulos não reiterativos do tipo pleonástico, em que a figuratividade é a mesma descrita na legenda, já servia em Duchamp. Daí os títulos como A noiva despida pelos seus celibatários, mesmo ( $L a$ mariée mise à nu par sés célibataires, même), conhecido também como o grande vidro, de Marcel Duchamp (figura 1.8).

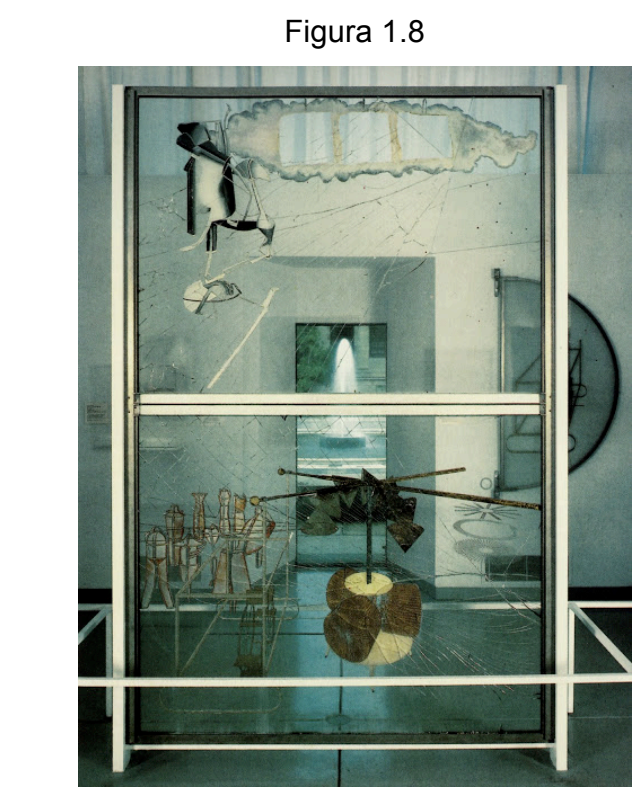

A noiva despida pelos seus celibatários, mesmo

(Marcel Duchamp, 1915-1923)

Nesse caso, o título da obra tem uma função de orientação do sentido, uma função de ancoragem. Mas não só. $O$ verbal também é matéria de expressão artística. Não há propriamente uma repetição entre a figura e a legenda. Por exemplo: em Almoço na relva de Manet, a legenda descreve a cena apresentada, diferentemente do que ocorre na figura 1.6, A praia, de Duke Lee. 
Como afirma Octavio Paz (2008, p. 20-51), o grande vidro é um texto que devemos decifrar, divide o mundo das artes em uma "modernidade" que começa e ainda não tem forma, porque rompe com uma tradição, já que é uma "obra voltada sobre si mesma, empenhada em destruir aquilo mesmo que cria", utilizando os artifícios da ironia nos enunciados verbais Sobre o título da obra de Duchamp, o ensaísta diz:

\begin{abstract}
Em primeiro lugar mise à nu não quer dizer exatamente despida ou desvestida; é uma expressão muito mais enérgica que nosso particípio: posta a nu, ex-posta. Impossível não associá-la com um ato público ou um rito: o teatro (mise-en-scène), a execução capital (mise à morte). Usar a palavra solteiro (célibataire) em lugar da que pareceria normal, noivo ou pretendente, indica uma separação infranqueável entre o feminino e o masculino: o solteiro não é nem sequer pretendente e a noiva não será nunca desposada. [...] $\mathrm{O}$ advérbio même - ainda, também, inclusive, até etc. - sublinha a ação e converte-a em uma verdadeira exposição, no sentido litúrgico e também no mundano (PAZ, 2008, p. 31-32).
\end{abstract}

Não se trata, como podemos perceber, apenas de nomear uma tela, mas também de dar nova orientação de sentido; nesse caso, o título contribui para o sentido pictórico. Na obra de Wesley Duke Lee, em alguns casos, vamos encontrar reflexos dessa preocupação do mundo das artes. O enunciatário pode, como já vimos, deparar-se, por exemplo, com elementos expressivos, cujo valor semântico é constituído pelo próprio plano da expressão, com o auxílio verbal dos títulos inseridos no texto pictórico.

Para compreender melhor o caminho que traçamos, é imprescindível que entendamos como foi o processo de formação da arte brasileira do século XX.

Embora a arte seja um processo contínuo, no qual as nomenclaturas não devem ser tomadas como estanques, devemos contextualizar os movimentos de arte no Brasil, mesmo que de forma breve, passando rapidamente pelo contexto histórico internacional.

Vale lembrar que abstracionismo e figurativismo constituem duas balizas entre as quais a arte sempre se desenvolveu pela continuidade ou pela ruptura. Para termos uma ideia dessas duas posições, basta olhar para a arte chamada indígena ou decorativa de nossos antepassados, ou mesmo para a arte do Egito antigo ou da Grécia antiga com seus desenhos geométricos decorativos e estilizados. Se compararmos uma tela da Op Art com uma pintura corporal indígena, bem como vasos gregos e egípcios, vamos verificar que o princípio orientador de sua 
composição é o mesmo, como podemos notar na figura 1.9. Embora sejam concepções de arte muito distintas, grosso modo pode-se dizer que no Egito, na Grécia antiga ou na arte indígena não havia o recorte de "arte abstracionista" ou "abstrata", mas existia arte com as características do que chamamos hoje arte abstrata.

Figura 1.9

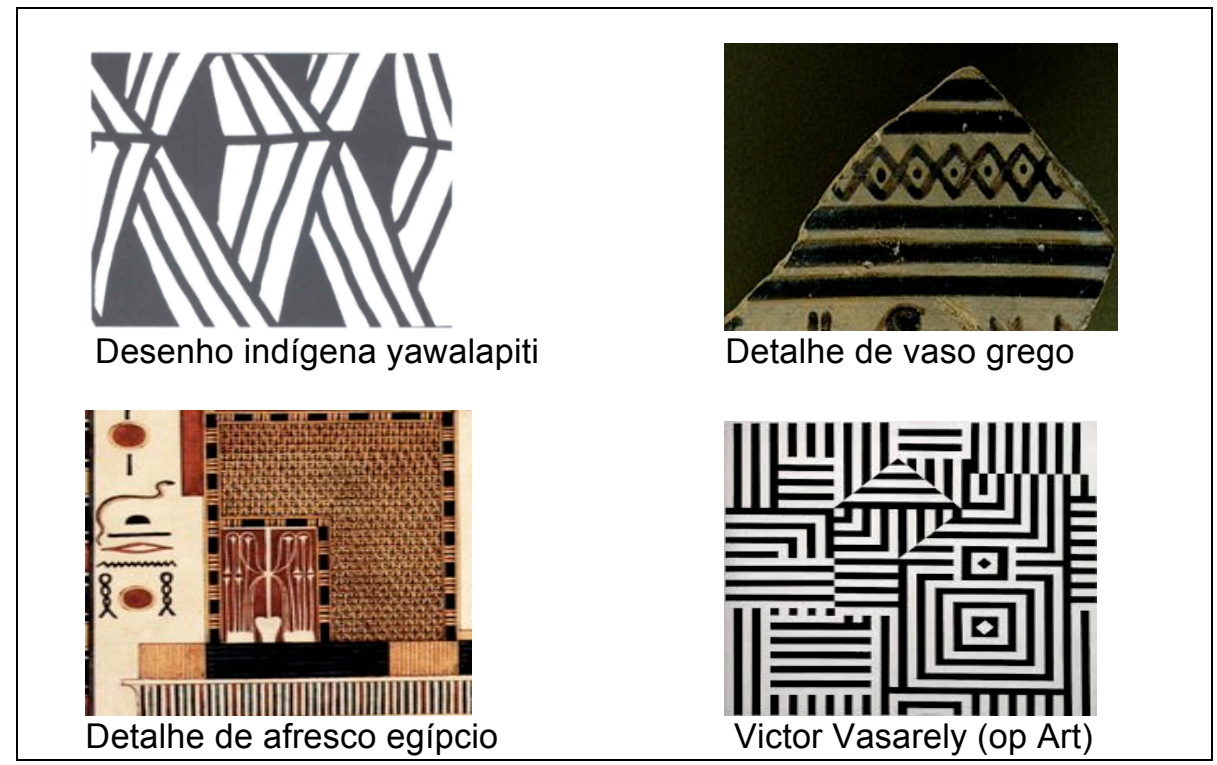

Não que inexistam, nessas culturas, obras destinadas à representação. Haverá obras indígenas, gregas e do Egito antigo que constituem simulacros da realidade. Todavia, ao lado delas, há outras que são meramente decorativas, constituídas apenas de formas geométricas, eventualmente evocadoras de semantismos míticos.

Como afirma Fiorin (2008, p. 53), a arte não tem a função de reproduzir a realidade; pode às vezes ocupar-se tão somente de criar outros mundos:

A grande função da arte não é dizer o que sempre existiu, mas
iluminar a possibilidade de outras existências, sugerir que outras
ordens da realidade são possíveis. Por isso, a arte tem sempre um
caráter subversivo, mostra-nos que a ordem vigente não é única, não
é absoluta, mas é uma entre outras.

Em termos mais gerais, o que consideramos arte abstrata ou arte figurativa deve ser sempre cuidadosamente inserido dentro de um período histórico, no caso da história da arte; estamos falando de uma progressiva dissolução da representação de uma figura em direção a uma abstração, processo que recebe alguns adjetivos. Para sermos mais diretos, temos a chamada: (1) abstração não objetiva ou informal, abstração lírica; (2) abstração geométrica ou analítica, e (3) 
expressionismo abstrato e tantos outros "-ismos" decorrentes dos processos de dissolução de figuras representacionais.

Nosso foco é, inicialmente, a arte no Ocidente, a partir da Primeira Guerra Mundial, ou seja, primeira metade do século $X X$, tomando como partida artistas expoentes como Kandinsky, conhecido por ser o "primeiro artista abstrato", para, em seguida, irmos em direção das diferenças na arte brasileira e seus desdobramentos a partir da Segunda Guerra Mundial.

Se quisermos ser mais abrangentes, poderemos incluir nesse paradigma da arte abstrata outros artistas e outros movimentos artísticos que fogem das nomenclaturas. Turner, com seus "nevoeiros", caminha para o Impressionismo, cujos artistas, como Monet (Impressão, sol nascente, 1872), Vincent Van Gogh e Cézanne seriam precursores da pintura abstrata, caso queiramos incluí-los nesse paradigma. Esses artistas constituíam seus enunciados, mesmo que de forma inconsciente, de fortes elementos de abstração, particularmente devido às técnicas empregadas na execução de suas obras. O que sabemos é que a linguagem abstrata ou não figurativa é o resultado de um longo processo. Desde o que chamamos de arte antiga (arte clássica grega) até o século XVIII, os artistas criaram um conceito de "realidade figurativa" fundado em valores convencionais e tinham como base um acordo sobre a objetividade e comunicabilidade, uma vez que deviam "imitar" ou representar a "natureza".

A partir do século XIX, porém, criou-se, segundo Waldemar Cordeiro, um "naturalismo que não imita o mundo exterior, não representa a natureza, mas pesquisa objetivamente os estímulos que revelam a natureza fisiológica da percepção humana" (In: FERREIRA; COTRIM, 2006, p. 110). A partir de então, os artistas ocuparam-se de criar uma linguagem própria que priorizava uma representação das "coisas" cada vez menos reconhecíveis até a suposta autonomia dos signos plásticos dentro de sua própria organização e relação para dar sentido à obra de arte por si mesma.

De acordo com os preceitos de uma tendência (destinadores), podemos verificar como em alguns artistas a abstração pode ser notada, sem antes estes artistas estarem em conformidade com o termo abstrato. Por exemplo, em Monet há uma progressiva tentativa de fugacidade nas pinceladas, cada vez mais difusas e espaçadas que deveriam se fundir perceptivelmente na retina daquele que olha 0 quadro, para dar sentido de cor; em Van Gogh, percebemos a atuação de uma 
gestualidade (produzindo um efeito de sentido de rapidez) presente nas camadas grossas de tintas e num domínio aparentemente impreciso da pincelada (isso quando ele utilizava pincel).

Esses exemplos nos mostram que nossa percepção, ao observarmos as obras de arte desse período (final do século XIX), é orientada não apenas para as características do plano de conteúdo, mas também para as características do plano de expressão que solicitam a participação do enunciatário.

Se tomarmos, por exemplo, um enunciado de Van Gogh, podemos observar que o sentido se forma tanto no plano da expressão quanto no do conteúdo. Seus traços característicos também são orientadores do sentido. O enunciatário pode, a partir do resultado da construção semiótica, proporcionada pela enunciação, depreender o éthos de um ser angustiado e inconformado com o mundo. Não há preocupação de se conformar com a realidade. Daí o nervosismo do traço, o carregamento das tintas? Vejamos a seguir nas figuras 1.10 e 1.11 alguns exemplos de obras que já prenunciavam limiares da abstração:

Figura 1.10

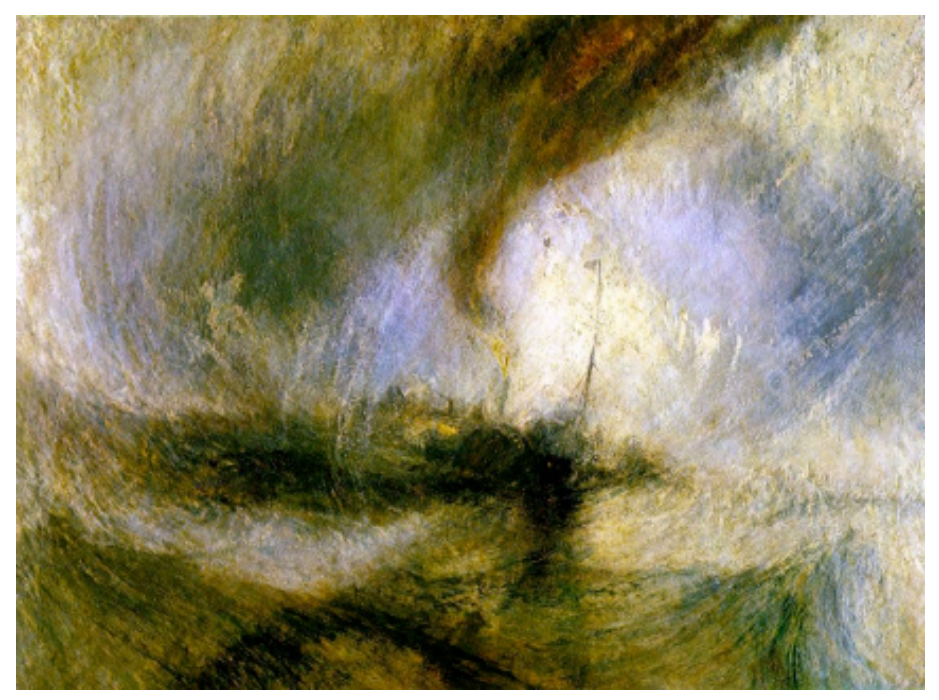

Tempestade de neve: navio ao largo do porto

(William Joseph Mallord Turner, 1842, óleo s/tela, 91,5 x $122 \mathrm{~cm}$ ) 


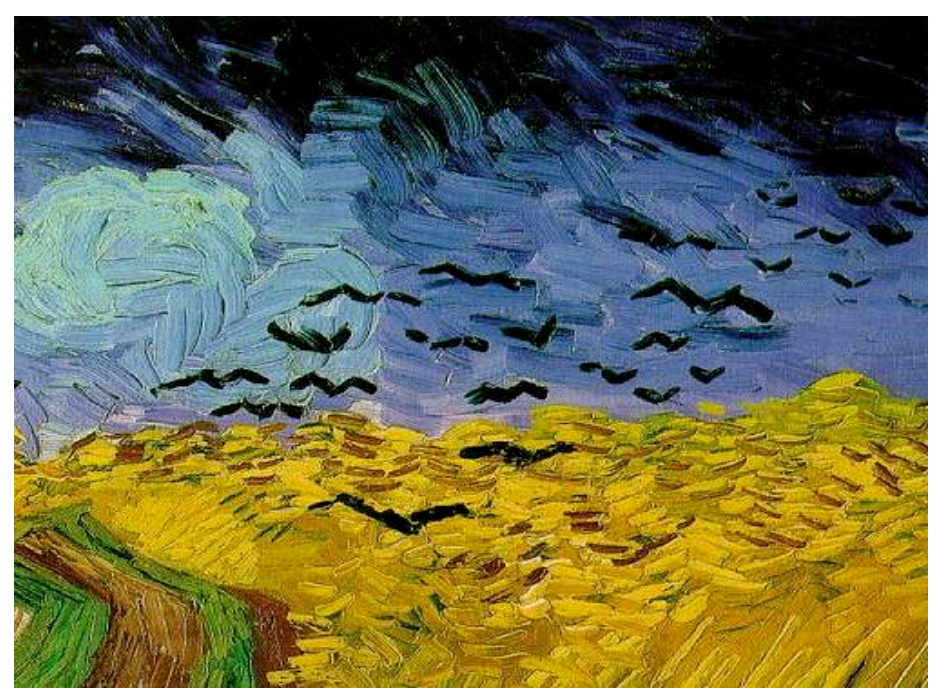

Campo de trigo com corvos (detalhe)

(Vincent Van Gogh, 1890, óleo s/tela, 50,5 x $103 \mathrm{~cm}$ )

No detalhe da obra Campo de trigo de Van Gogh, vemos que os valores como a gestualidade e a sobreposição de camadas de tintas fazem parte de sua prática pictórica. Figurativamente, vemos pássaros sobrevoando um campo de trigo. Novamente, temos em questão o sujeito da enunciação: as escolhas do enunciador pressupõem um enunciatário competente para a produção do sentido; suas figuras afastam-se gradativamente do mundo natural em direção a uma abstração. Os pássaros não são propriamente simulacros de pássaros da natureza (corvos), sobretudo se considerarmos a ocorrência de um pássaro concreto. Os pássaros de Van Gogh levam-nos, antes, em direção a um pássaro-tipo, mera ideia reduzida ao mínimo identificável: um pássaro esteno-gramático, mais ou menos como aqueles que é capaz de pintar uma criança bem jovem.

O céu guarda similitude com o espaço apenas pela cor; e o campo de trigo também não reproduz mimeticamente o cultivo de trigo, mas tão somente sua cor amarela.

Se o enunciatário se dispusesse a pensar a obra de Van Gogh como abstrata, se não houvesse título na obra que o conduzisse ao sentido e se pensasse na relação cromática apenas, poderia entender que a composição não passa de um exercício de harmonia. O azul e o amarelo são cores que, adicionadas ao círculo cromático, círculo das relações harmônicas entre as cores, podem remeter ao grupo de cores complementares, caso sejam adicionadas a essas cores outros matizes. 
O enunciador, com base nesses detalhes, poderia supor que o amarelo adicionado ao ocre pode remeter ao mesmo efeito de sentido cromático que acontece nos pares de cores complementares azul e alaranjado ou violeta e amarelo, por exemplo. Não podemos saber qual foi a intenção do enunciador, mas sabemos que suas escolhas nos possibilitam concluir que o recorte do analista é importante para segmentar o objeto artístico. Ou seja, será que poderíamos enquadrar Van Gogh como artista abstrato, caso nossa compreensão de sua obra fosse dada pelo recorte de abstrato, como uma composição puramente destinada pela relação das cores?

Como não podemos, nem seria o nosso propósito, estabelecer demarcações precisas entre arte abstrata e figurativa, devemos nos ater aos modos de operação da matéria da pintura, de acordo com suas regras, convenções e predominância de determinados valores estéticos depreensíveis do enunciado de suas obras. Semioticamente, interessa-nos como se forma o sentido em uma obra plástica.

Voltando ao Brasil, ao que nos parece, a arte nacional não estava em consonância com as experiências de vanguarda europeias no inicio do século $X X$ muito embora tentasse criar um diálogo estreito com as vanguardas europeias. Nas artes plásticas, o Modernismo, ao se preocupar em transmitir valores nacionais, dava sempre importância excessiva à dimensão descritiva de uma obra de arte, o que contribuiu para o sentimento de indiferença em relação à arte abstrata que vinha de fora, já preocupada com a matéria da pintura.

No entanto, devemos ressaltar que o "moderno" no Brasil não é melhor ou pior que os movimentos de vanguarda europeus, mas apenas diferente. O modernismo, após a fase heroica com seus fundadores, Anita Malfatti, Tarsila do Amaral e Mário de Andrade, por exemplo, desenvolveu pesquisas que fortaleceram o poder de comunicação dos meios artísticos; em contrapartida, rejeitava o caráter abstrato das obras de arte que começavam a ocupar espaço, já no final de 1930, a partir da exposição conhecida como "Salão de Maio".

Para os acadêmicos oriundos da Escola Imperial de Paris, os modernistas já exploravam, na pintura, uma verdadeira ruptura com a pintura "referencial", uma vez que incorporavam a "deformação" no seu repertório. Foi nesta mesma década que Candido Portinari começou a desfrutar de fama nacional e internacional, já que havia recebido um prêmio de menção honrosa nos Estados Unidos por sua tela Café (figura 1.12), na Exposição Internacional de Arte Moderna organizada pelo Instituto 
Carnegie. Em sua obra, Portinari (ver figura 1.12) procurava conciliar "sua visão humanista e seu interesse por questões sociais a uma intensa pesquisa plástica" (COUTO, 2004, p. 40).

Figura 1.12

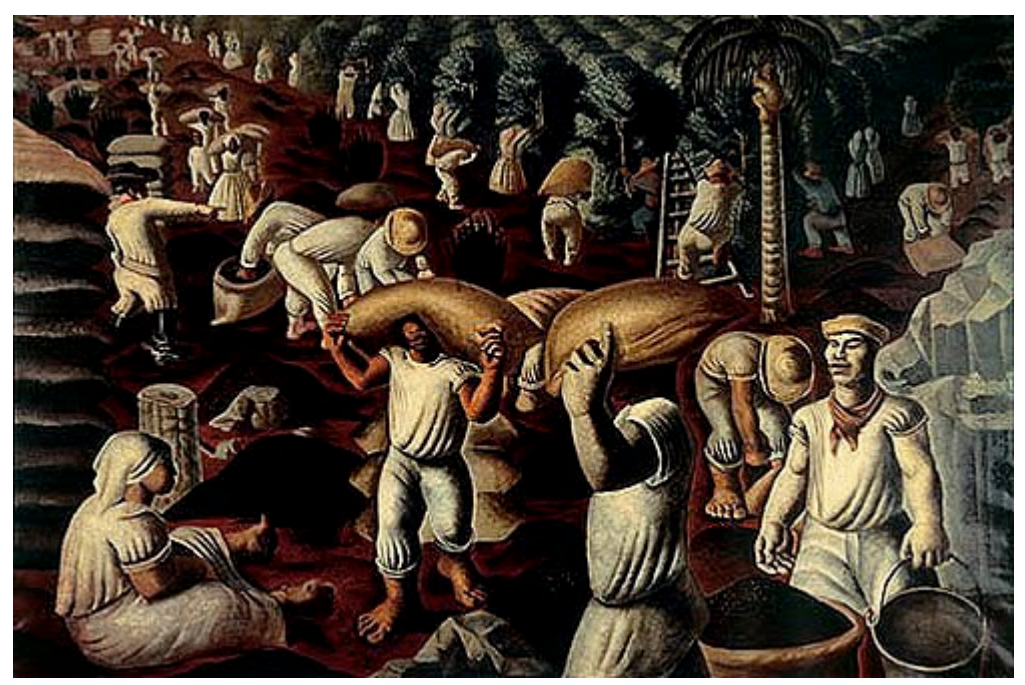

Café

(Portinari, 1934-1935, óleo sobre tela, $130 \times 195 \mathrm{~cm}$ )

Nas décadas de 1940 e 1950, chegaram ao Brasil, em razão da Segunda Grande Guerra, artistas e intelectuais do Velho Continente. Esse fato estreitou os laços brasileiros e europeus e criou um ambiente de trocas culturais que agiu positivamente, oferecendo alternativas e novas soluções estéticas que iriam além das convenções locais dos ideais nacionalistas para os artistas do país.

Após a Segunda Guerra Mundial, a efêmera abertura política e as transformações de caráter industrial e econômico criaram um movimento de fertilidade para a arte. São criados, então, o Museu de Arte de São Paulo (Masp) e os Museus de Arte Moderna de São Paulo e do Rio de Janeiro, além da Escola Superior de Propaganda e do Instituto de Arte Contemporânea, que funcionaram nas dependências do Masp. Pela mesma época é criada a Bienal Internacional de Arte de São Paulo, cuja primeira edição ocorre em 1951.

Com a queda do Governo Vargas, o clima era ainda mais profícuo aos intercâmbios culturais para o debate entre artistas mais conservadores e artistas favoráveis às novas formas de expressão. Foram realizadas no Brasil diversas exposições de artistas tidos como abstratos; a principal delas foi a que ocorreu na 
inauguração do Museu de Arte Moderna de São Paulo, Do figurativismo ao abstracionismo, em março de 1949.

No entanto, a ideia de que apenas a arte figurativa poderia exercer uma função social legítima e ser acessível à compreensão de todos prevalecia no país. Havia por aqui: (1) um clima de discórdia entre os artistas que, por um lado, acreditavam que a arte só poderia contribuir para o mundo se o mundo soubesse ler a obra, ou seja, o acesso do público a uma obra de arte deveria ser feito pela proximidade realista daquilo que se pintava (a realidade figurativa/objetiva), aceitando-se apenas pequenas distorções; (2) por outro lado, havia artistas que se ocupavam de esgotar a materialidade plástica dos elementos constitutivos de uma "gramática" visual, como a cor e a linha e, portanto, eram abstratos. Além dessas duas posições, havia também (3) um pequeno grupo que acreditava que a arte não estaria nem no academicismo nem no racionalismo, mas na "figuração primitiva", chamada de arte naïf, e que esta seria a arte que melhor representaria o povo brasileiro.

$\mathrm{Na}$ ocasião desses acontecimentos, diversos textos de críticos de arte, ensaios jornalísticos e artigos de artistas contrários ao chamado abstracionismo, referiam-se às artes abstratas como: confusão medonha, modernismo metafísico, anarquismo modernista, podridão, monstruosidade.

A força da abstração no Brasil pode ser observada, mais adiante, pela adesão de muitos artistas hoje considerados importantíssimos para a identidade nacional e com alcance internacional. Muitos artistas aderiram às diversas vertentes dos movimentos de origem abstracionista, a começar pelo eixo Rio/São Paulo, com os grupos Frente e Ruptura, respectivamente. Estavam nesses grupos artistas como Geraldo de Barros, Alexandre Wollner, Haroldo de Campos, Augusto de Campos e Décio Pignatari em São Paulo; no Rio de Janeiro, Ivan Serpa, Lygia Clark, Hélio Oiticica, Almicar de Castro, Lygia Pape, Ferreira Gullar, Mario Pedrosa. Afora esses grupos, havia também a produção de artistas como Manabu Mabe, Tomie Otake, Flavio-Shiró, Frans Krajcberg, Iberê Camargo, Fayga Ostrower, entre outros.

Os grupos que se formaram eram radicais em seus textos e manifestos, assumindo também a vontade de instaurar uma nova era artística no país.

No final da década de 1950, no entanto, observamos o enfraquecimento das tendências abstracionistas e uma retomada da pintura carregada de figuras humanas, urbanas e industriais, irradiada pelo chamado espírito pop, tendência bastante atuante nos Estados Unidos e ligada ao Futurismo, ao Surrealismo e ao 
Dadaísmo na Europa. Já em 1960, os Novos Realistas, na casa de Yves Klein, em Paris, por intermédio de Pierre Restany, assinaram um manuscrito a giz em que discutiam o que seria o Novo Realismo, recusando a abstração e afirmando uma nova abordagem perceptiva do real.

Nessa época, a arte brasileira vive uma fase fecunda, identificando-se como "adequada às necessidades de um país novo, que poderia entrar em concorrência direta - em nível de igualdade, ou mesmo de superioridade - com a produção europeia" (COUTO, 2004, p. 17).

Em suma, existe um conjunto extenso de "modernidades", como fábricas, a própria cidade urbanizada, a publicidade, os mass media, a ciência e a tecnologia que circundam essa nova natureza a ser explorada. Os artistas, cada qual com sua linguagem, regulam sob suas medidas e regras individuais as experiências que recebem em seus contextos próprios. Ou seja, cada experiência é individual e essa experiência resulta das combinações de repertório e da formação de cada artista.

Assim, esses artistas não estão necessariamente copiando ou se apropriando desses movimentos artísticos internacionais e reproduzindo o que chamamos de happenings e instalações. Além do mais, trata-se de uma nova maneira de introduzir a linguagem verbal como ancoragem, tanto como meio de construção da significação e identidade do objeto artístico, quanto para desvelar o aparato conceitual linguístico usado pelas instituições de arte para conferir significado de objeto de arte, como na arte conceitual e nos readymades, como os de Duchamp. Eles se apropriam também, através da colagem, de técnicas de reprodução de imagens, como a serigrafia e o xerox, como é possível notar nas figuras (figuras 1.13 e 1.14) abaixo em que comparamos uma obra de Duke Lee com uma obra de Rauschenberg: 
Figura 1.13

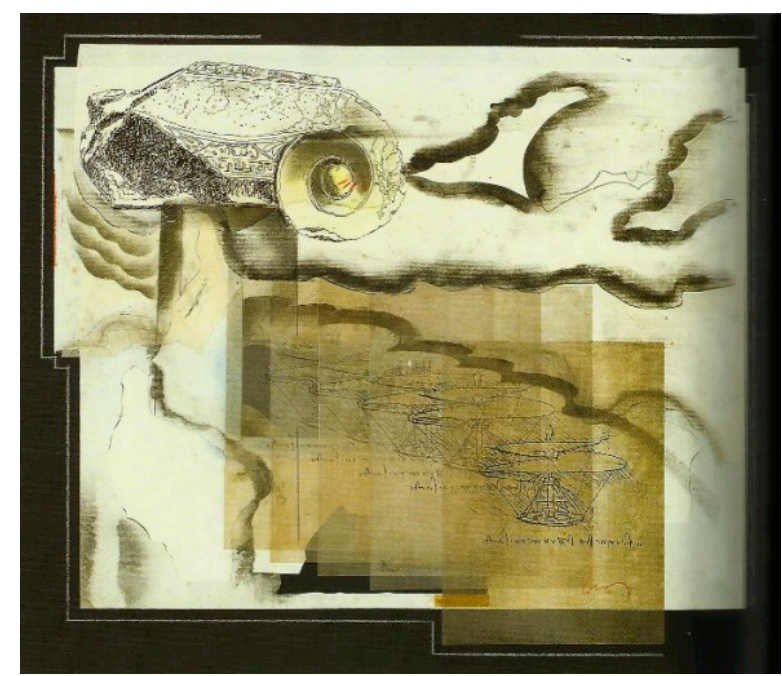

Retorno à base dy Saint-Amèr

(Wesley Duke Lee, 1977, aquarela, xerox e colagem s/ papel, 62,5 x $73 \mathrm{~cm}$ )

Figura 1.14

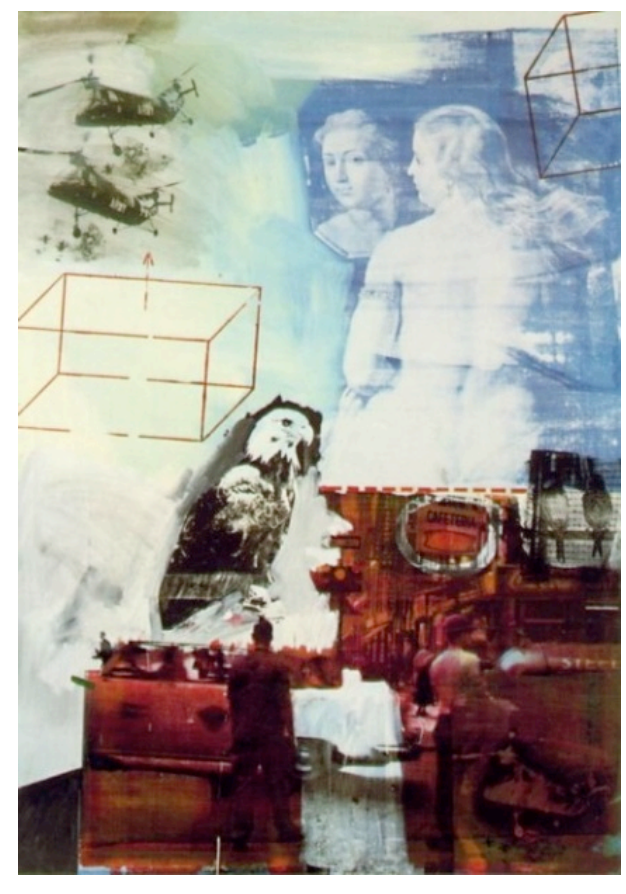

Tracer

(Robert Rauschenberg, 1963, óleo e silkscreen sobre tela, 213,68 cm x 152,4 cm)

Conforme podemos ver nas figuras 1.13 e 1.14, a visão de mundo dos artistas está sempre em consonância com aspectos das tendências das artes. Mesmo quando um artista segue um cânone internacional de regras de composição, ainda assim sua visão de mundo não será a mesma, como podemos observar. Assim, embora haja um diálogo com artistas internacionais, já notamos a formação de uma identidade artística nacional. 
Todos esses elementos expressivos, como o xerox, a colagem, as citações foram se consolidando e assimilados pelos artistas que, assim, assumiram certo tipo de tendência figurativa ligada, principalmente, ao Futurismo, ao Surrealismo e ao Dadá. Vale lembrar que essas tendências figurativas irradiaram-se a partir dos Estados Unidos e da Europa (final da década de 50-60), rumo ao Japão e América Latina e obtiveram sucesso porque se adequavam às circunstâncias de cada país e cultura, com designações próprias. Não houve, como no caso do Impressionismo, uma única exposição, ou uma primeira obra de arte que se destacou e fez surgir um movimento chamado Nova Figuração. É por isso que se fala em um "espírito pop" que abarcou diversas produções artísticas em diversos países. Na América Latina, por exemplo, houve o movimento Outra Figuración, Novo realismo, Mitologias Cotidianas, Novas figurações, Equipo Crónica e Crónica de La realidad. Todas as vertentes se diziam antagônicas à $P o p$ art, diferenciadas por não terem se originado nos EUA e terem assimilado cada um à sua maneira esse "espírito pop" (COSTA, 2009, p. 23-25).

$\mathrm{O}$ que essas tendências têm em comum, dentre outros elementos é um tipo especial de figuração, mediada pelos meios de comunicação de massa, como a propaganda, revistas em quadrinhos, bandeiras, embalagens de produtos, objeto de uso cotidiano, estereótipos gerados pela fotografia (clichê tipográfico), serigrafia, cinema, televisão e pela imprensa. Esse fenômeno não foi isolado e fruto unicamente de uma nação, mas constituiu-se de aspectos da visão de mundo das últimas décadas do século XX. No Brasil, a volta da figuração também sofreu diversas influências.

A nova figuração brasileira, portanto, foi estruturada, paulatinamente, por uma tendência a novas organizações, que gerou, por sua vez, na pintura, uma tendência a atitudes expressivas de negação da continuidade e voltadas para o uso de materiais pré-codificados, bem como para a interação com o público. A esse conjunto de figurações, no Brasil, decidiu-se chamar de Nova Figuração, uma convenção arbitrária, porém, cultural. De acordo com Costa (2009 p. 24),

no Brasil, por exemplo, a volta à figuração teve muitos matizes. Sofreu a influência das produções concreta e neoconcreta que a precederam e demonstrou, principalmente depois de 1964, uma conexão profunda com o movimento político e social do país, desvinculando-se da Pop art norte-americana. 
Se, antigamente, o Brasil se amparava em discursos e tendências importadas da Europa ou Estados Unidos, a partir das décadas de 1950 e 60 o Brasil se atualiza e se insere nas novas tendências, além de exportar não só artes plásticas, mas também a produção muito particular da arquitetura e da música da época (Niemeyer, João Gilberto, Tom Jobim).

A arte brasileira do final dos anos 50 e início dos anos 60 assume uma postura não mais de submissão em relação às movimentações externas (LOPES, 2009, p. 32), mas de igualdade. Por exemplo, os artistas brasileiros passam a se interessar pela Pop arte americana, mas se apropriam, de maneira muito particular, dos elementos que as constituem, cada qual à sua maneira.

Wesley Duke Lee, no nosso caso, possui qualidades como domínio técnico e sensibilidade apurados e se apropria das tendências artísticas europeias e americanas, e o faz manifestando referências, citações e recorrências diretas ou indiretas às personagens da literatura universal. Nesse sentido, pode-se dizer que se trata de um artista altamente bem informado com o universo das artes.

\subsection{Nova Figuração Brasileira e o Realismo Mágico}

Não entraremos aqui em detalhes desse diálogo com o exterior, visto que foram atuações mútuas de vários agentes nesta transformação da arte brasileira; contudo, dentre os vários representantes dessa nova geração, a Nova Figuração, é importante destacar nessa constelação de nomenclaturas e distinções, entre um e outro dito "movimento artístico", Wesley Duke Lee, justamente pelo fato de participar efetivamente do universo artístico contemporâneo e, ao mesmo tempo, ir além. Lee é um artista que rejeita todos esses rótulos, por assim dizer.

Como se sabe, alguns artistas sentem dificuldade de se inserir em determinadas estéticas ou as rejeitam fortemente. Salvo quando esses mesmos artistas proclamam sua arte através de manifestos e decretos de autoafirmação, nós entendemos que a denominação de um movimento depende de um distanciamento e, normalmente, ele é etiquetado por críticos ou historiadores, depois de certo tempo. Adiante veremos como Wesley Duke Lee pode ser visto como um dos maiores protagonistas da Nova Figuração Brasileira e enquadrado como Realista Mágico (como ele gostava de ser chamado). Como tantos outros artistas, Duke Lee teve uma relação turbulenta com o mundo das galerias e museus. No entanto, como 
afirma Costa (2005, p. 83), nem sempre Wesley Duke Lee teve relação conflituosa com o meio:

[...] Por um lado conseguiu apoios relevantes advindos de sua colaboração com Pietro Maria Bardi ou da compreensão significativa de Walter Zanini [...]. No exterior - Japão e Estados Unidos despertou $\mathrm{o}$ interesse de galeristas e também dos diretores do Museu de Arte Moderna de Tóquio; de Thomas Messer, diretor do Guggenheim Museum de Nova York; de Walter Hopps do Pasadena Art Museum; e de Maurice Tuchman do Los Angeles County Museum of Art.

A personalidade de Duke Lee também pode ser conferida num texto de Carlos Felipe Saldanha, denominado Kid Camarão, como podemos ver no texto denominado "Biografia Mágica de Wesley" (In: LOPES, 2009, p. 41-42):

Vivem me perguntando o que é o Realismo Mágico. Se é movimento, escola, filosofia, religião, guestalte, baurraus, zen, yê-yê, etc., etc. Eu respondo que não é nada disso, que Realismo Mágico é Rex. Aí me perguntaram o que é Rex. É a resposta que eu dei, Bidu! Eureka ou pas Eureka, eis a questão. Arkadin Wesley Duke Lee d'y Saint Amer é Rex. Os índios Apaches são Rex. O Condor, que é aquele aribu metido a águia, que aparece todo vermelho numa tela de cinema toda de vermelho, sai voando e vira letrinhas, e a gente ri à bessa porque outro dia tudo era roxo, é Rex. Um livro preto e velho, de 1935, cheio de gravuras minúsculas em hachurado grosso, de finanças ou de gramática pode ser por si só uma porca velharia. Mas basta os Rex dizerem:

_ "Isto é Rex" e pronto, o livreco caquetz passa a ser Rex, e portanto, uma consumada obra de arte. É isto que nossos adversários não aguentam. Aqui cabe uma observação: Elefante Rex só de borracha. Vamos, agora, a um pequeno teste: Aqueles livros que a gente abre e os bonecos ficam de pé, em cima da folha, são Rex? Heim/Resposta: "o truque é Rex, os bonecos não são".

Porque pouca gente desenha Rex no globo terráqueo, é quase só Wesley. Por isso esta exposição é fundamental na reformulação da Arte Brasileira. Não sei se já repararam, mas nesta arte brasileira de hoje em dia tudo é novo, o romance novo, o novo novo, o ovo novo. Só o Realismo Mágico é velho. Os Rex são uma Geração Tardia. Rex é uma paródia ao mau gosto. É o realejo da revolta contra o bom gosto novo e o intelectualismo novo. Rex é Pedro Álvares Cabral, João Ramalho, o português na cova dos leões, os Bezerros de Ouro voando, em esquadrilha, em direção à Ilha de Rodas, e deixando cair panfletos com dizeres insidiosos:

O Realismo Mágico Há de Vencer.

Ibis Ibidem

Kid Camarão 
O nome Rex foi Duke Lee que deu ao grupo formado depois da exposição Pau Brasil, realizada em 1964 na Galeria Atrium, SP. Era um nome de um cachorro seu. Teria dado esse nome ao grupo porque considerava digno: se os demais artistas fossem como o cachorro dele, "seria muito melhor".

Além das rejeições sofridas pelas galerias, Wesley achava-se inferior aos artistas eruditos e intelectuais críticos de artes que lia em revistas dedicadas a esse tema e aos amigos que fizera durante seus estudos nos Estados Unidos e Europa, pertencentes a "famílias patrícias e à cultura erudita" (COSTA, p. 24, 2005). Talvez esse sentimento de inferioridade possa ter sido importante para a sua trajetória cada vez mais individual e solitária em busca de uma identidade própria.

Estar em acordo com a nomenclatura Realista Mágico seria como a materialidade de um elemento marcante em sua personalidade, a ironia. Esta reflete a sua busca por uma identidade, que, vestido do papel de enunciador, poderíamos depreender também seu éthos. Como sabemos, a imagem de si é construída pelo discurso, não apenas no texto, mas também nas competências não linguísticas e culturais que compreende o universo do discurso. Há todo um conjunto de características semióticas que podem ser observadas na relação enunciadorenunciatário e que são assumidas pelo enunciador como componentes estilísticos, que constituem um modo de ser e de fazer específicos.

Fiorin (2008, p. 143), afirma que:

dentro desse todo, procuram-se recorrências em qualquer elemento composicional do discurso ou do texto: na escolha do assunto, na construção das personagens, nos gêneros escolhidos, no nível da linguagem usado, no ritmo, na figurativização, na escolha dos temas, nas isotopias.

No caso da Série das ligas, é através da observação das escolhas enunciativas (tanto da ordem do verbal quanto visual), dos temas e demais isotopias do plano da expressão ou do plano do conteúdo, que podemos construir uma imagem de seu enunciador.

Não é o fato de Duke Lee se assumir um realista mágico que faz dele um artista desta categoria; no entanto, podemos reconhecer traços e marcas em sua obra que remetem aos valores aos quais ele se filia.

Aliás, quando analisamos sua obra, o que se evidenciam são traços pertinentes de sua personalidade no interior de sua obra como um todo. Ao longo do processo de construção de uma identidade, podemos dar caráter primordial à continuidade 
dada por ele a conceitos, ideias e preocupações estéticas advindas das coerções que determinada técnica escolhida apresenta ao artista, e como ele procurou resolver tais questões ao longo deste processo. Portanto, estamos falando novamente das escolhas enunciativas que, a nosso ver, são escolhas que podem ser determinadas por grandes destinadores.

Wesley Duke Lee afirma:

muitas vezes já me perguntaram: "você fala do quê?"Quando respondo que falo de mim: "mas o que você pensa que é?" Não interessa, a proposta é essa: eu posso falar de mim, posso falar de meu lugar, não dos outros. $E$ não me preocupo, pois à medida que fui desenvolvendo as ideias, vi que em todo grande acontecimento quem o realizou estava falando de si. (COSTA, 2005, p. 15)

No século XVI, pintores iniciantes eram influenciados por artistas de grandes obras do Renascimento, bem como por escultores da Antiguidade Clássica Grega. $O$ destinador, aquele que influencia, é o responsável pela continuidade dos fazeres nas artes (cf. TATIT, 2010, p. 20). Nos museus, através do exercício do desenho e gravura desses aprendizes, é possível detectar a continuidade da escola clássica nas reproduções de obras pictóricas dos grandes mestres como Rafael, Poussin, Ticiano, Rubens, como podemos verificar a seguir na figura 1.16, que é produzida porque foi destinada pelo destinador da figura 1.15 .

Figura 1.15 - O destinador é Poussin.

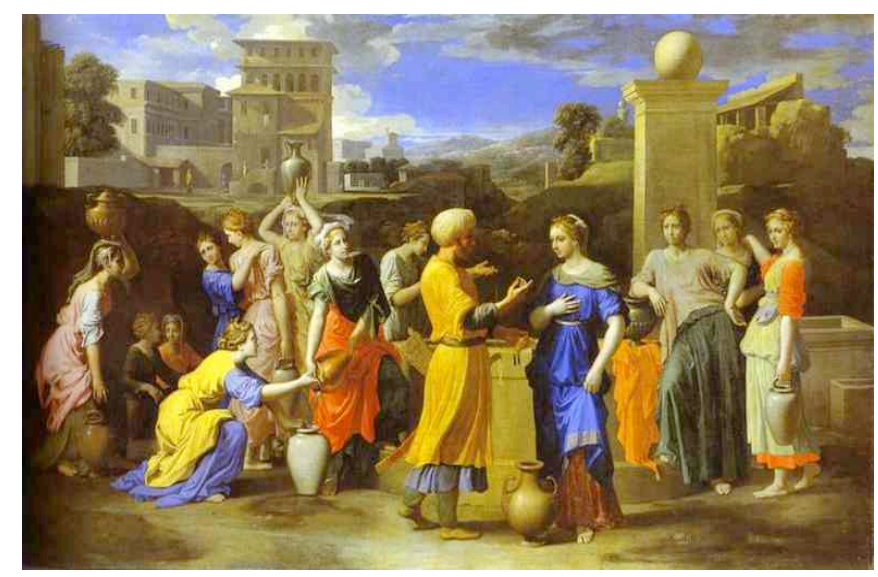

Eliezer e Rebecca

(Nicolas Poussin,1648, óleo sobre tela, $118 \times 199 \mathrm{~cm}$ ) 
Figura 1.16 - O destinatário sujeito é Rousselet.

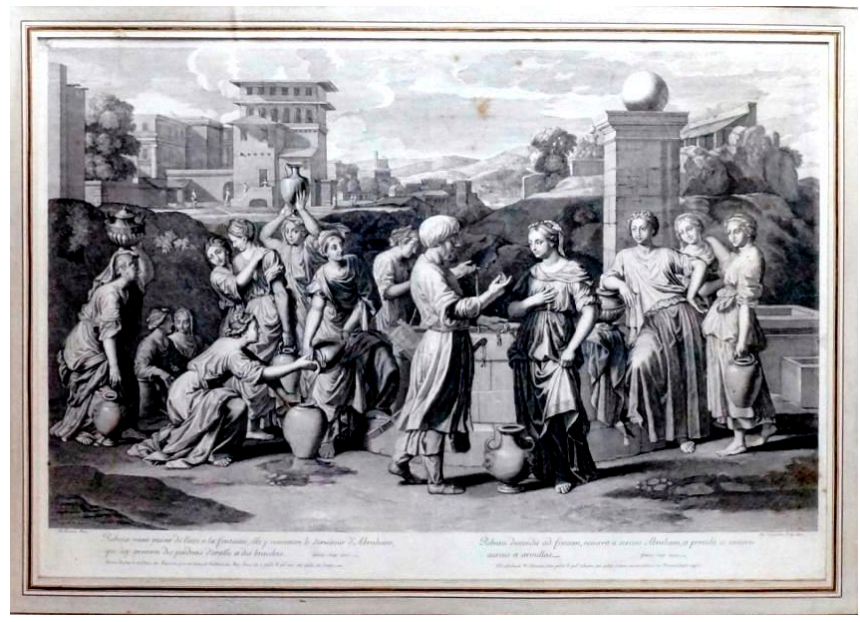

Eliezer e Rebecca

(Gilles Rousselet, 1677, gravura 44 x $65 \mathrm{~cm}$ )

Neste caso, poderíamos pensar que o destinador da figura 1.15 seria a técnica de representação daquilo que supostamente seria a "beleza", encontradas nessas obras nos recursos plásticos e nos exames dos corpos: (a) a representação das paixões faciais; (b) a performance dos atores do quadro: suas expressões na face e movimento de corpos; O destinador aqui é o "saber fazer o belo".

Em Duke Lee, o diálogo que ele estabelece com tendências artísticas internacionais, como o Surrealismo, o Dadaísmo, o Cubismo, bem como com artistas, como Klimt, Egon Schiele e Paul Klee, pode ser reconhecido na sua produção artística. Comparando a figura 1.17 de Paul Klee com uma tela de Duke Lee (figura 1.18), podemos observar como esse diálogo se dá:

Figura 1.17

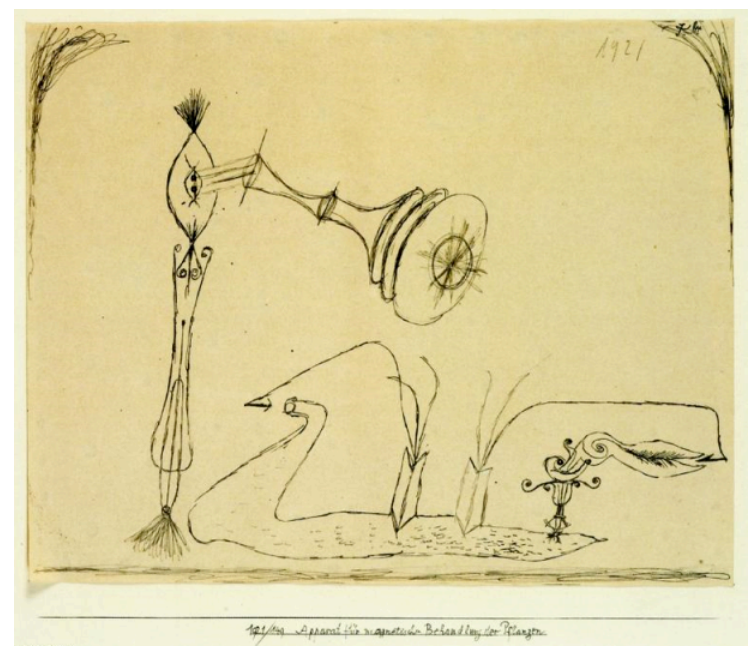

Aparelho para o tratamento magnético de plantas

(Paul Klee, 1908, gravura, $30 \times 24 \mathrm{~cm}$ ) 


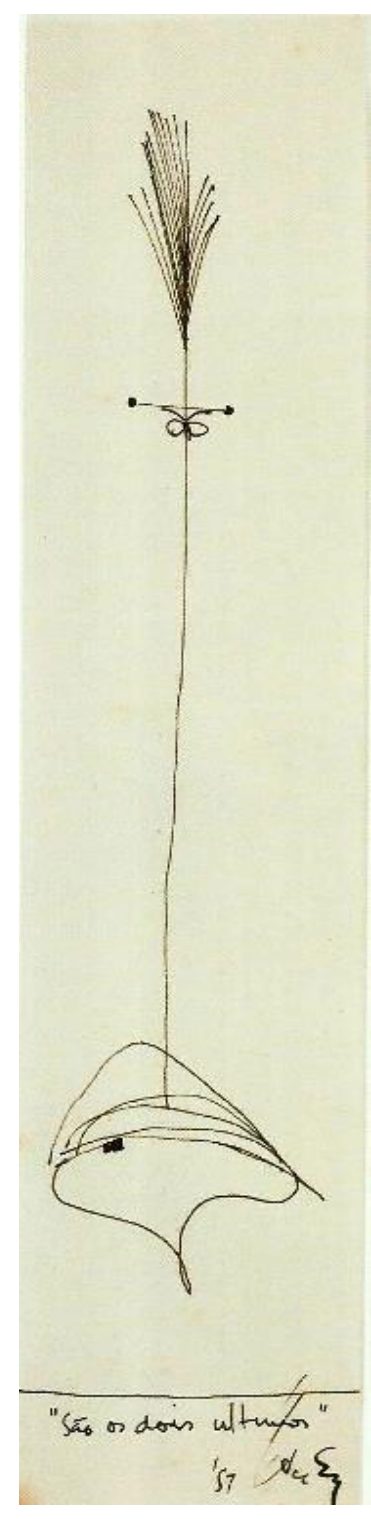

São os dois últimos

(Wesley Duke Lee, 1959, nanquim s/ papel, 19,5 x 4,2 cm)

Em ambas as obras, podemos verificar semelhanças nas linhas longilíneas e contínuas, monocromia, economia de traços, ausência de efeito do sentido de volume e ausência de tridimensionalidade, o que traduz uma escolha pela simplicidade, além da utilização da linguagem verbal (ambos os artistas inserem textos verbais no interior de suas telas, formando um sincretismo verbo-visual).

Essa característica de abertura ao diálogo com as mais diversas tendências artísticas é marcante no éthos de Duke Lee. Por outro lado, sua obra nos mostra um artista subjugado a restrições temáticas e expressivas, ou seja, às coerções tanto da ordem do estilo, quanto daquilo que pressupomos ser um dos destinadores de sua obra, que poderíamos supor poderia ser o clima intelectual e artístico de sua época. 
No entanto, para não cairmos em generalidades sobre os destinadores de sua obra, faremos uma seleção de momentos de sua vivência nos EUA para compreender como, supostamente, alguns artistas puderam influenciar direta ou indiretamente a formação de sua identidade enquanto artista.

Observando alguns dos exemplos inseridos neste capítulo em que comparamos algumas obras pictóricas de outros artistas que "destinaram" de certa forma, durante sua formação, a sua arte; a saber: a pop art norteamericana, o Novo Realismo europeu, o dada, o surrealismo e a jovem vanguarda neofigurativa brasileira. Wesley viveu em Nova lorque entre 1952 e 1955, em um momento em que grandes nomes das artes estavam sendo assimilados pelos EUA, como Marcel Duchamp, Francis Picabia, Man Ray, Salvador Dalí, Max Ernest, André Breton, Yves Tanguy. Nas palavras de Costa (2005, p. 20), esse momento da arte estadunidense

modificou a ideia de que a cultura norte-americana é banal e ingênua. Os artistas começaram a se identificar pelos ícones da sociedade norte-americana, pelas representações ligadas aos meios de comunicação de massa e objetos do cotidiano: bandeiras, dinheiro, imagens de propaganda e imitações. Paralelo ao grande movimento abstrato, algo novo, inédito e fascinante encontrava-se em gestação e colocar-se-ia dentro de poucos anos diante dos olhos de uma sociedade atônita.

Duke Lee ficou impactado quando, no Museu de Arte Moderna de Nova lorque esteve diante da obra de Marcel Duchamp, A regarder (L'autre côté du verre) d'um oeil, de près, pendant presque une heure (1918), "que ele seguiu à risca e ficou olhando com um olho só, por quase uma hora, e percebeu algo realmente novo, que dizia respeito à questão da incompletude da obra e da relação com o público -, e profundamente intrigante, embora realizado 30 anos antes" (Costa, 2005, p. 20).

Na biografia de Wesley Duke Lee, escrita por Cacilda Teixeira da Costa, podemos observar como ele percebeu algumas dessas influências a partir de trechos transcritos de seus diários ou como no depoimento a seguir:

Em Nova York, eu não creio que estivesse recebendo influência do pop. Não estava. Eu fui ver a primeira exposição do Rauschenberg num porão; um moço um pouco mais velho que nós ou mais formado. Mas o que havia era aquela ebulição dentro da sociedade americana e nela o espírito pop. Esse espírito é americano, do cotidiano, uma visão que já estava na primeira grande escola de pintura americana que é o Ash Can. [...]

O que realmente me emocionou foi o surrealismo e principalmente o grupo Dada, do qual havia muita informação. Aqui quase não havia informação visual do Dada. Era mais dos poetas e escritores Dada; 
mas lá eu tinha a visão plástica. Isso foi muito forte. Nessa época, era isso o que mais me impressionava: Dada, Marcel Duchamp, cuja descoberta para mim foi uma coisa extraordinária. Eu já sabia quem ele era; mas a informação sobre ele em 1952, no Brasil, era muito pouca. Quando cheguei lá, foi isso que me tocou a cabeça. Agora, se formos puxar as raízes do movimento pop, nos Estados Unidos, vamos bater nessas mesmas fontes (COSTA, 2005, p. 21).

Além do impacto que suas vivências tiveram sobre sua obra, podemos também atribuir ao aprendizado com Plattner grande domínio de técnicas e do seu processo criativo. Plattner foi um italiano que chegou ao Brasil em 1952, permanecendo aqui durante oito anos, participando de salões e dando aulas e com ele Duke Lee teve contato com o universo das artes, as disputas entre artistas engajados politicamente e partidários da abstração em contrapartida com aqueles que eram partidários do figurativo. Foi nesse meio que Wesley se deparou com as questões de cunho político que envolviam as artes. No entanto, parece que Lee buscou a conciliação entre a experiência abstrata e a expressão figurativa.

Com seu professor, Wesley intensificou o estudo do desenho e "das técnicas mais tradicionais como têmpera a ovo ou cera, afresco, douração, encáustica, gravura em metal e nanquim a bico-de-pena" (COSTA, 2005, p. 32) Seriam, portanto, as escolhas coercitivas de algumas das suas técnicas aplicadas à Série das ligas o seu destinador?

Duke Lee viajou durante muito tempo, juntamente com seu professor Karl Plattner, pela Europa, conheceu uma atmosfera intelectual nova e estabeleceu contato direto com obras e artistas que o influenciaram diretamente. Cacilda Teixeira da Costa (2005, p. 47) escreve que os artistas Wesley e Plattner

Viajaram pelas montanhas do Tirol, iam frequentemente a Zurique, Munique e Salzburgo. Em Munique, na Haus der Kunst, viu o que considerou a primeira coleção que o impressionou de fato: uma introdução aos movimentos Jugendstil até Blauer Reiter, que Ihe deram uma visão magnífica da época em que viveu Klee. "O pequeno Klee saltou aos olhos no meio de toda a bagunça!" (diário, Munique, 15 ago. 1958).

Em Viena, aprofundou seu conhecimento das obras de Klimt e Schiele e desfrutou da companhia civilizada de jovens diplomatas, como Rogério Corção e da pianista Gilda Oswaldo Cruz, aos quais Carlos Felipe Saldanha muitas vezes se reunia. Nessa convivência, conheceu personalidades como Raul Bopp e realizou diversas viagens, entre elas, uma excursão a Berna para conhecer a grande coleção de Klee, e outra às minas de carvão da Bélgica, o mundo de Magritte. Fizeram visitas a coleções particulares, ou a Merano, para conhecer e fotografar Ezra Pound (o que fez sozinho, com grande 
emoção, lembrando-se até hoje da conversa que tiveram sobre Pisanello). [...] Descobrira um ambiente de cultura, requinte intelectual, talentos individuais e de uma certa fidalguia decaída cuja intimidade desvendava pela primeira vez.

Em 1960, ele registra em seu diário nomes de artistas que considera importantes para sua formação:

\author{
Nova geração alemã: \\ Klaus J. Fischer \\ Jürgen Schmidt \\ Wolff Barth \\ Heróis: \\ Antoni Tapiès \\ Alberto Burri \\ Lucio Fontana \\ Wols \\ Dubuffet \\ Juan Miró \\ Influências sadias: \\ Schiele, Egon \\ Klimt, Gustav \\ Anjos: \\ Paul Klee \\ Picasso
}

(diário, Bolzano, 31 jan. 1960)

(COSTA, 2005, p. 48)

Observamos anteriormente, nas figuras $1.12,1.13,1.16$ e 1.17, que, quando comparamos as obras de alguns artistas com as de Lee, encontramos figuras que são quase citações (intertextualidade), sejam elas diretas ou indiretas, de artistas que Duke Lee admirava. É possível encontrar essas citações tanto no plano da expressão quanto no plano do conteúdo, como já dissemos.

Os elementos constitutivos de uma obra de arte, de maneira geral, quando agrupados por um "especialista", ou um historiador, devem possuir, em alguma escala, elementos que os aproximem. Uma série só se faz propriamente quando, ao compararmos, encontrarmos nela elementos que confirmem suas relações e valores. É dessa maneira que podemos dizer que Wesley Duke Lee é um artista que recuperou a figuratividade no Brasil. Nesse sentido, ficou conhecido como um artista que criou o movimento chamado Nova Figuração, por estabelecer concordância e dialogar com artistas que recolocaram a "figurativização" no âmbito da pintura, a 
partir das tendências ligadas ao Futurismo, ao Surrealismo, ao Dada, a Marcel Duchamp.

No Brasil, os artistas não se incluíram no rótulo de Pop art. Alguns dos nossos artistas acreditavam numa arte não figurativa e outros buscaram introduzir novos meios de construção da "figura", como o próprio Duke Lee. Além dele, poderíamos citar outros nomes como Nelson Leirner, Antonio Dias, Rubens Gerchman, Artur Barrio, Siron Franco, muito embora eles não fossem todos partidários das mesmas atitudes expressivas. Ou seja, não formavam um grupo de artistas nem um movimento, como a Pop art e o Novo Realismo Francês. Nesse contexto, Lee desenvolveu um trabalho inovador, preciso no traço e ousado na
mistura de materiais e técnicas, retomando a figuração na chave da
fantasia, do onírico, do "realismo mágico". Seu estúdio logo se tornou
o ponto de encontro de jovens artistas interessados em ampliar seu
campo de conhecimento nas artes plásticas (COUTO, 2004, p. 202).

Por isso, dizemos que o realismo de Duke Lee não é da mesma linha do Novo Realismo francês, tampouco da Pop art, que se valia da realidade dos meios de comunicação de massa; ela, a Pop art norte-americana, retirava seus objetos de seus contextos e os ressignificava.

Embora Wesley seja identificado como realista mágico, na verdade o Realismo Mágico nunca foi um movimento de arte que abarcou outros artistas por uma unidade estética, diferentemente, pois, do Cubismo cujas marcas estéticas conferem unidade e identidade aos artistas que fazem uso dos valores geométricos ali escolhidos, por exemplo. No Realismo Mágico não temos a formação de um grupo facilmente identificável. Ora, não pertencer a um grupo nem poder ser identificado pode dar um efeito de sentido de um éthos de alguém que se queira singular. No entanto, examinando as dez telas de Duke Lee, percebemos influências de variados artistas.

Na tela denominada Hilda Angélica é de se observar a técnica da colagem como faziam Braque e Picasso. Em Anêmona circense, por sua vez, notamos a presença de traços e cores de Toulouse-Lautrec. Em Ode erótica a Lydia, as escolhas cromáticas são as mesmas de Egon Schiele. 


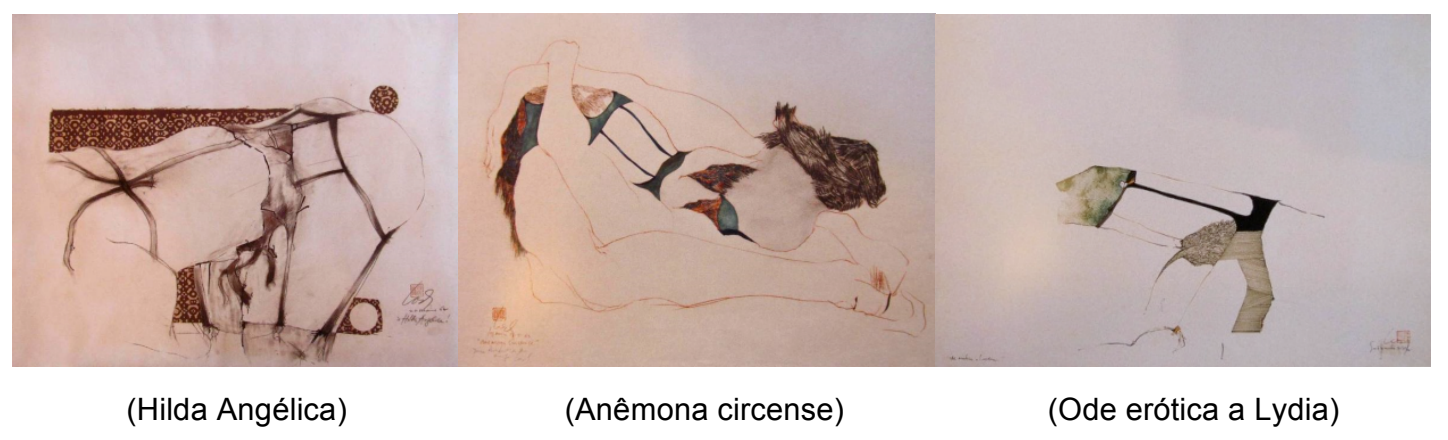

Outras características suas são a ironia, a irreverência, a intertextualidade, a parodia, que podem ser verificadas tanto nos elementos de ordem visual quanto verbal; muitas vezes, os títulos de suas telas são enigmáticos, criando um efeito de sentido de uma arte refinada e pouco acessível, como podemos ver na figura 1.20:

Figura 1.20

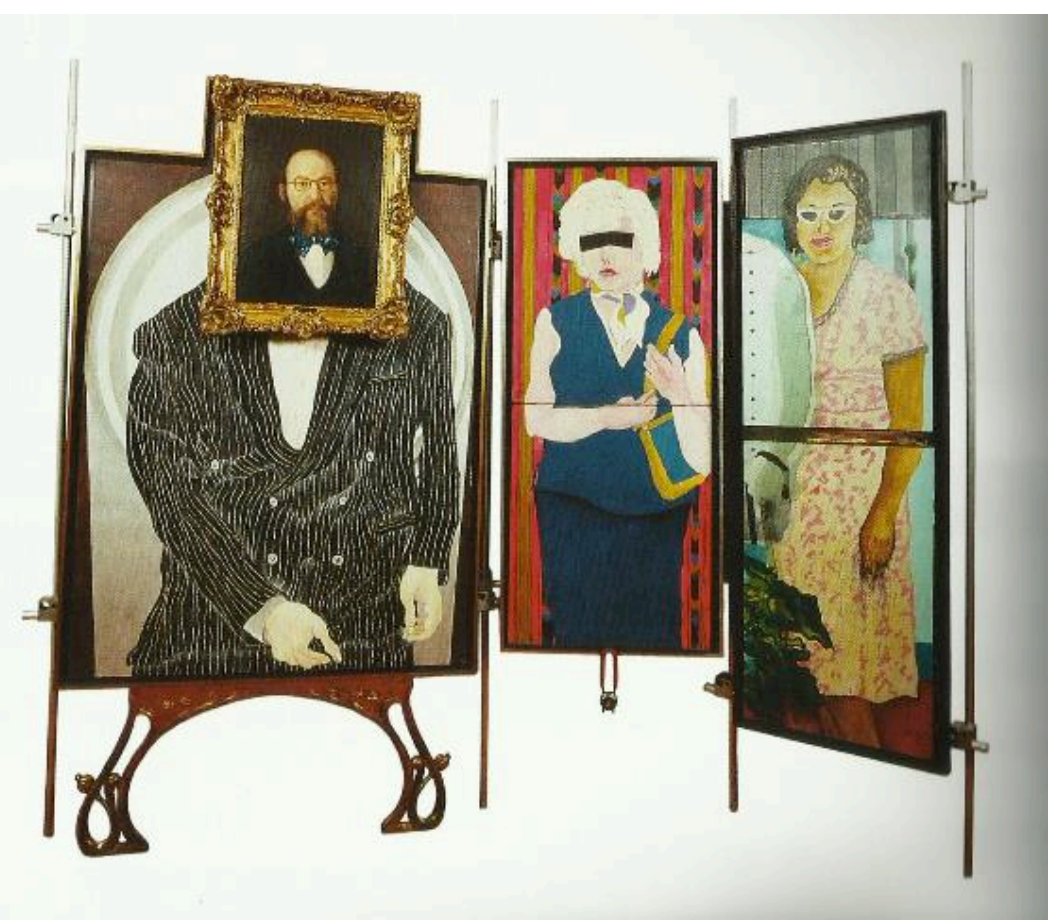

O nome do cadeado é: as circunstâncias e seus guardiões (tríptico composto de: o guardião, o cadeado, a guardiã).

(Wesley Duke Lee, 1966, tinta acrílica, tela plástica, metal e pintura de José Ferraz de Almeida Júnior, $197 \times 107 \mathrm{~cm}, 136 \times 60 \mathrm{~cm}, 150 \times 56 \mathrm{~cm})$.

$\mathrm{Na}$ figura 1.20, em que Duke Lee inclui em sua obra um retrato de Almeida Júnior, podemos reconhecer o caráter paródico de sua experiência artística. Almeida Júnior compartilha o espaço com outras imagens e retratos de pessoas "menos importantes" para o cenário artístico. 
São pessoas comuns que Duke Lee insere no mesmo contexto, dessacralizando, assim, o pintor e mestre do academismo brasileiro Almeida Júnior, como se estivesse também questionando a tradição da pintura acadêmica, a tradição da pintura de cavalete. Dessa forma, a paródia funciona como um artifício para equiparar dois universos culturais distintos, ora enobrecendo o que é comum e o que é vulgar, ora empobrecendo e desmitificando o que já é consagrado.

Essas intertextualizações são comuns na obra de Duke Lee; em geral questionam ou afirmam valores tanto referentes ao plano de expressão, quanto referentes ao plano do conteúdo.

Ainda em relação à paródia, vejamos um trecho retirado de seu discurso ao final do happening em que a Série das ligas foi exposta:

[...] eu gostaria de aproveitar este momento para publicamente fazer uma homenagem à Crítica que desde o começo de minha carreira vem me incentivando e ajudando nesta muito minha e particular pesquisa. Pela Perspicácia e sensível observação, pela originalidade na classificação artística, nas nuanças do metier. Gostaria que este crítico aqui presente recebesse a totalidade de minha gratidão, transcrevendo e decifrando ao grande Público os curiosos e inesperados caminhos que o desenvolvimento artístico atravessa (COSTA, p. 87).

Wesley possui uma arte inventiva e ao mesmo tempo sutil em que não só cria objetos artísticos, mas também brinca com seus discursos, suas falas e transforma sua vida em um realismo "mágico" que pode ser atribuído ao tipo de humor presente nas ambiguidades dos títulos de sua obra. 
O JOGO SEMIÓTICO DO EROTISMO 


\subsection{Erotismo e tensividade}

Muito do que se discute sobre erotismo pode ser confrontado com o termo pornografia. A distinção entre um e outro é, muitas vezes, juízo de valores locais, culturais, morais e subjetivos.

Desse modo, é comum que os termos erotismo e pornografia sejam avaliados, o primeiro como positivo (eufórico), dele enobrecendo-se certos aspectos, e o segundo como negativo (disfórico), visto que o erotismo não estaria relacionado explicitamente à sexualidade. Na pornografia, explora-se necessariamente o contato genital, considerado muitas vezes vulgar. No entanto, as coisas podem não ser tão evidentes assim.

Pietroforte (2007, p. 85-96), em "A construção da imagem, entre o erótico e o pornográfico", ressalta que a tematização do discurso erótico é relativa ao sexo; há uma projeção de forias sobre as escolhas feitas em cada discurso específico. $\mathrm{Na}$ segunda metade do texto, ele aborda a questão particular do erotismo e suas distinções e oposições entre natureza vs. cultura. No caso de um discurso utilitário sobre sexo, segundo o autor, o discurso mais comum seria o da valorização eufórica e, quando se trata de fantasias sexuais, ou seja, discurso existencial do sexo (utópico), a valorização seria disfórica. Mesmo assim, poderia haver uma inversão fórica em cada eixo de valorização no discurso utópico.

A prática erótica torna-se paixão do desejo e do entusiasmo, se euforizada; se disforizada, torna-se luxúria, ou é vista como pecado. Assim, o discurso erótico será definido de acordo com a valorização do sexo em determinados discursos. Ressalta o autor que

cada tipo de erotismo define o sistema de categorias próprias para eleger o motivo da valorização existencial de sexo: no heterossexual, é a categoria semântica masculino vs feminino; no homossexual, identidade vs alteridade; no sadomasoquista, opressão vs liberdade; no fetichista, totalidade vs parcialidade; no necrófilo, vida vs morte; e no pedófilo, novo vs velho (PIETROFORTE, 2007, p. 92). 
Mais uma vez, estamos diante de oposições que dependem do contexto social, cultural, moral, religioso etc., e que, por isso, não são definições estanques, causando-nos dúvidas e incertezas semióticas.

Outro problema dessas definições subjetivas estaria baseado nos pares de oposição: implícito vs explícito. A partir de meados do século XIX, em decorrência da indústria cultural de massa, poderíamos pensar no par de distinção: cultura de massa vs cultura erudita. Branco (1984, p. 68) pressupõe que a pornografia, produzida geralmente em série e com objetivo principal de comercialização e consumo, recai sobre a cultura popular de massa, facilmente digerida, e o erotismo, sobre um público mais seleto e menor, o público degustador da arte, aí correspondente a uma modalidade não utilitária de prazer.

Resumindo, a distinção entre erotismo e pornografia evoca oposições das quais, de tão prolixas, poderíamos elencar apenas algumas, citadas por Maingueneau (2010, p. 31) como, por exemplo:

direto vs indireto, masculino vs feminino, selvagem vs civilizado, grosseiro vs refinado, baixo vs alto, prosaico vs poético, quantidade vs qualidade, chavão vs criatividade, massa vs elite, comercial vs artístico, fácil vs difícil, banal vs, original, unívoco vs plurívoco, matéria vs espírito etc.

Nosso objetivo é mostrar que o discurso da Série das ligas, de Wesley Duke Lee, é da ordem do erotismo dinâmico, ora mais plástico, ora mais mimético, não fazendo parte do universo cultural da pornografia.

A seguir, faremos um levantamento do verbete erotismo nos dicionários com a finalidade de investigar uma possível cifra tensiva para esse termo. Em seguida, avaliaremos como isso tudo está configurado nos textos pictóricos de Duke Lee.

\subsection{Modalização do erotismo: um estudo do léxico}

Erotismo é derivado de Eros, deus grego, regente do desejo sexual. Consideremos as definições dicionarizadas dos verbetes erotismo, erotização, eros e erótico: 
EROS: "Desejo de sensação; descoberta de sentido"

(LE ROBERT, Dictionnaire étymologique, 2008, verbete eros).

ERÓTICO, EROTISMO: "Que suscita desejo"

(DEVOTO; OLI, 2005, verbetes erótico, erotismo).

ERÓTICO, EROTISMO: Que provoca desejos; excitante; tornar interessante" (BORBA, 2002, verbetes erótico, erotismo).

EROTIZAÇÃO, EROTISMO: "Modo de prazer; estímulo"

(PETIT ROBERT, 2008, verbetes erotização, erotismo).

Como podemos notar, a maioria das definições dos dicionários revela-nos a sintaxe do "querer descobrir", "querer sentir", "querer estímulo". Quanto maior o efeito de aproximação, maior será a participação do enunciatário; maior sendo a participação, maior a intensidade do desejo, de querer descobrir, completar o enunciado.

Se instigado pelo título "Ligas", intensifica-se a participação do enunciatário nas telas em que o preenchimento é mínimo. Aqui, o erotismo se tonifica. Quanto maior o interesse pelo procedimento de preenchimento do enunciatário, maior o desejo, mais erótico. Se o preenchimento é avançado, menor a participação do enunciatário, menor a intensidade do erotismo.

Em telas clássicas, há erotismo obviamente, como vimos na seção 1.1, "Objetividade e subjetividade", comparando o erotismo de Bouguereau e o erotismo de Duke Lee. No entanto, o grau de sensibilização do objeto é que poderá determinar a intensidade desse erotismo. $O$ apelo ao erotismo não está ligado diretamente ao "parecer imperfeito", mas àquilo que se entrevê.

Desse modo, maior participação, maior desejo, maior "atividade" do enunciatário: em maior ou menor grau, a depender do grau de estetização do objeto.

Assim temos:

\section{Erotismo tônico $\rightarrow$ maior intensidade de efeito de sentido de aproximação/participação}

Erotismo átono $\rightarrow$ menor intensidade de efeito de sentido de aproximação/participação 
Esse desejo de descoberta tem como programa de base alcançar a conjunção com o objeto, levando o sujeito a buscar atingir a plenitude. É o erotismo, por exemplo, que coloca em jogo a continuidade do sujeito incompleto (BATAILLE, 2013, p. 128-129).

Se, para Bataille, o ser está incompleto (ver tradição de Eros e a descontinuidade do ser perfeito na seção 2.3, "O programa semiótico do erotismo"), para Greimas, a incompletude se dá pelo objeto (tela do parecer). Em Da imperfeição, Greimas explicita como uma sensibilização maior pode provocar o sujeito de maneira intensa, a ponto de fraturar os acontecimentos do cotidiano, havendo uma fusão sensorial do sujeito com o objeto.

Segundo Fiorin,

há diferentes graus de identificação do sujeito com o objeto artístico. Há aqueles que se identificam com a substância do conteúdo: a realidade retratada na obra literária. Por outro lado, há os que se buscam no objeto sua construção, sua arquitetura, sua forma, seja da expressão, seja do conteúdo (FIORIN In: LANDOWSKI; DORRA; OLIVEIRA,1999, p. 106-107).

Nesse aspecto, o objeto erótico das Ligas pode garantir a busca pela apreensão dos elementos constitutivos da gramática plástica, traduzidos em figuras femininas para a construção do efeito de sentido erótico. Alguns traços sensoriais, como "efeito de aproximação" causado pelas telas da Série das ligas, produzem um efeito de estesia, que, no nosso entender, seria o mesmo do erotismo: a "busca da conjunção" com o objeto que está desfigurado, esvaziado.

O objeto erótico das Ligas, que oscila entre o erotismo figurativo e o erotismo plástico, ora pelas representações diretas e miméticas de partes de um corpo nu, ora pelas rupturas da "imitação do mundo natural", joga com a construção desse objeto. Como podemos notar, o objeto estético aproxima-se ou mais de um pólo ou de outro. Estes não devem ser vistos como descontinuidades, mas como pontos de chegada em um continuum, que vai do mais figurativo ao mais plástico. Se Duke Lee apresentasse mimeticamente um corpo feminino nu, estaríamos na ordem do figurativo, sendo menor sua intensidade estética. 
A linguagem enigmática dos textos ${ }^{3}$ eróticos mantém o contrato fiduciário entre enunciador e enunciatário; ambos querem conservar o objeto erótico intacto, querem o objeto erótico recortado, assimilado, depreendido. No entanto, os textos eróticos convocam o enunciatário com maior ou menor intensidade, de acordo com as estratégias enunciativas.

De outra forma, se antecipadamente revelado o erotismo de tal objeto (objetividade), antecipadamente também poderia se encerrar o encanto do enunciatário pelo objeto. Se a semiose entre expressão e conteúdo já estivesse esclarecida ou escancarada, poderia não haver o desejo de descobrir e, portanto, o encantamento erótico seria de menor intensidade. Bataille (2013, p. 53) afirma também que no erotismo está em jogo um aspecto inapreensível e não necessariamente uma imagem objetiva de uma mulher. Considerando a figura 2.1, o enunciatário é estimulado a procurar as ligas que o título da obra lhe propõe:

Figura 2.1

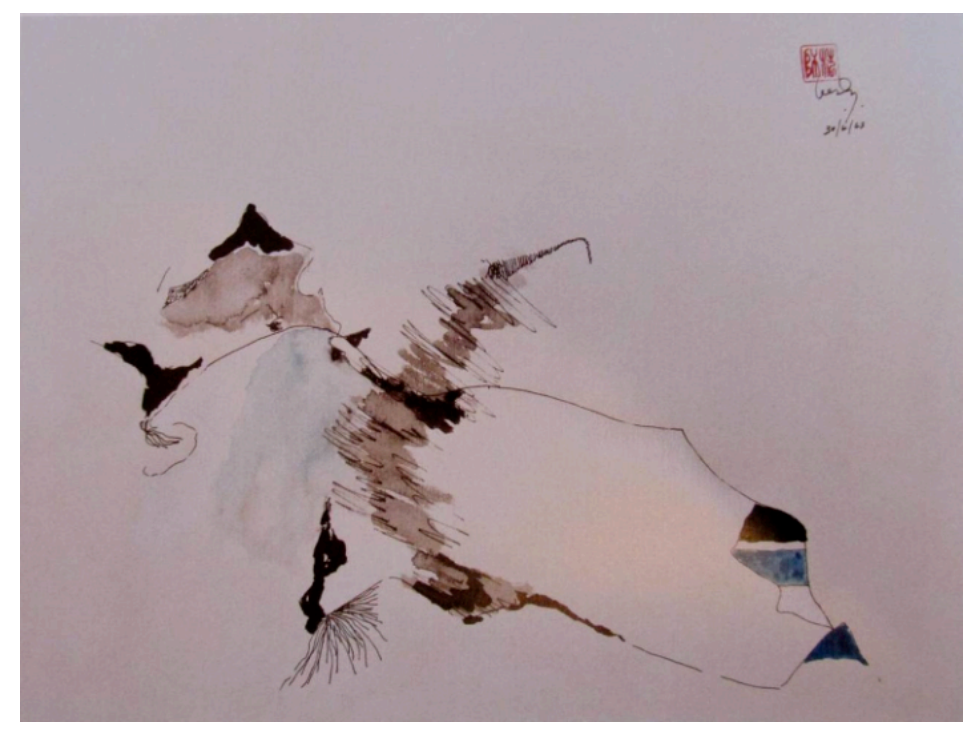

Série das ligas

(Wesley Duke Lee, 1963, nanquim e aquarela s/papel, 32 x $43 \mathrm{~cm}$ )

Na figura 2.1, o título tem função de ancoragem como já explicitamos antes. Sem ele, o enunciado poderia ser confundido com algo que se aproxima da abstração. Assim é que, se não fosse a indicação de títulos que constam das lâminas da Série das ligas, o enunciatário, embora impactado, ficaria desorientado em busca de um sentido. O título direciona para o campo semântico "LIGAS",

\footnotetext{
${ }^{3}$ Entendemos por texto uma pintura, um filme, uma poesia, ou seja, qualquer relação semiótica entre plano de expressão e conteúdo.
} 
instigando o enunciatário a reconhecê-las; há, então, a instauração de um desejo de erotismo que está velado na tela e rompe com a isotopia do erotismo figurativo, direcionando o olhar para um erotismo de ordem plástica. Essa divisão, como temos visto, é de caráter explicativo apenas.

É por isso que afirmamos anteriormente que o desejo de descoberta por parte do enunciatário, diante das Ligas, tem como programa de base alcançar a conjunção com o objeto, levando o sujeito a buscar atingir a plenitude. Ele quer que o erotismo plástico dure. Enquanto o enunciatário estiver construindo a "imagem", ele estará em conjunção com o objeto. Quanto maior o empenho, maior o efeito de sentido estético, mais próximo estamos do erotismo plástico.

\subsection{Programa semiótico do erotismo}

No mito grego, Eros é o deus do amor, que aproxima, mescla, une, multiplica as espécies vivas. A ideia de união poderá se dar nos textos artísticos, não se restringindo apenas à união sexual-amorosa, mas, estendendo-se de maneira geral, à ideia da busca da conjunção com o objeto, mais propriamente de uma completude passageira.

A noção de impulso erótico como busca de conjunção e conexão tem nascimento na Antiguidade Clássica no texto $O$ Banquete, de Platão. Aristófanes narra que a humanidade, antes do surgimento de Eros, era composta por três sexos: o masculino, o feminino e o andrógino. Os seres andróginos possuíam quatro mãos, quatro pernas, duas faces, dois genitais, quatro orelhas e uma cabeça. Esses andróginos resolveram desafiar os deuses e foram, por isso, castigados por Zeus que os dividiu em duas partes. Desse modo, eles ficaram enfraquecidos e perderam a competência amorosa, restando neles apenas a capacidade utilitária de reprodução, para serem mais numerosos e servirem aos deuses.

Após essa divisão, os novos seres, mutilados e incompletos, passaram a procurar suas metades correspondentes. Dá-se o mito de Eros: a busca impulsiva pela conjunção com a finalidade de recomposição da natureza antes completa e agora atingida pela falta. O programa de base a se atingir era, então, a restauração da identidade.

Como vimos, o mito de Eros deixa-nos rastros do início da instauração de uma falta fundada na relação semiótica solidária entre feminino e masculino. Essa bipartição coloca o feminino como sujeito restaurador da ordem e da plenitude por 
vários fatores. O principal deles, esboçado no mito por Aristófanes, é o de que o feminino, nesse caso, teria a possibilidade de conjunção pressuposta pela maternidade, ainda que passageira, pois o corpo da mulher é capaz de englobar dentro de si o corpo de outro indivíduo em formação.

$\mathrm{Na}$ transição do século XVIII para o XIX se começa a notar um discurso que desconstrói a ideia de um sexo único, hierarquizado para dar lugar a um modelo fundado em dois sexos distintos e bem diferenciados. Nesse contexto, afirma Birman (2001, p. 34), "não existiria qualquer possibilidade de reversibilidade entre os sexos, dado que suas essências seriam radicalmente diferentes".

Georges Bataille (2013), em seu livro O erotismo, desenvolve essa mesma ideia: a busca da continuidade dos seres humanos, a tentativa de permanência além de um momento fugaz. Para esse autor, a fusão Eros-Tânatos não apenas estabelece uma falta, como afirmava, mas também traduz um "querer permanecer" por meio da fusão com o outro, o desejo de continuar, de superar a morte por um impulso contrário.

No entanto, o impulso em direção à unidade e à totalidade é sempre momentâneo, podendo os indivíduos alcançar a plenitude da conjunção apenas em estado de arrebatamento. No entendimento de Bataille, erotismo é uma função intermediária entre vida e morte. Aqui, podemos bem fazer uma ligação do pensamento de Bataille com a semiótica tensiva, que ultrapassa as oposições extremas ou "só vida" ou "só morte" ou "só natureza" ou "só cultura", estabelecendo que o sentido oscila gradativamente.

Bataille (2013) atribui ao desnudamento grande valor, não se detendo, porém, no nu, no escancaramento. $O$ processo de desnudar-se paulatinamente retardaria 0 fruir do enunciatário, o que nos permitirá identificar um andamento mais lento na tela seguinte (figura 2.2): 


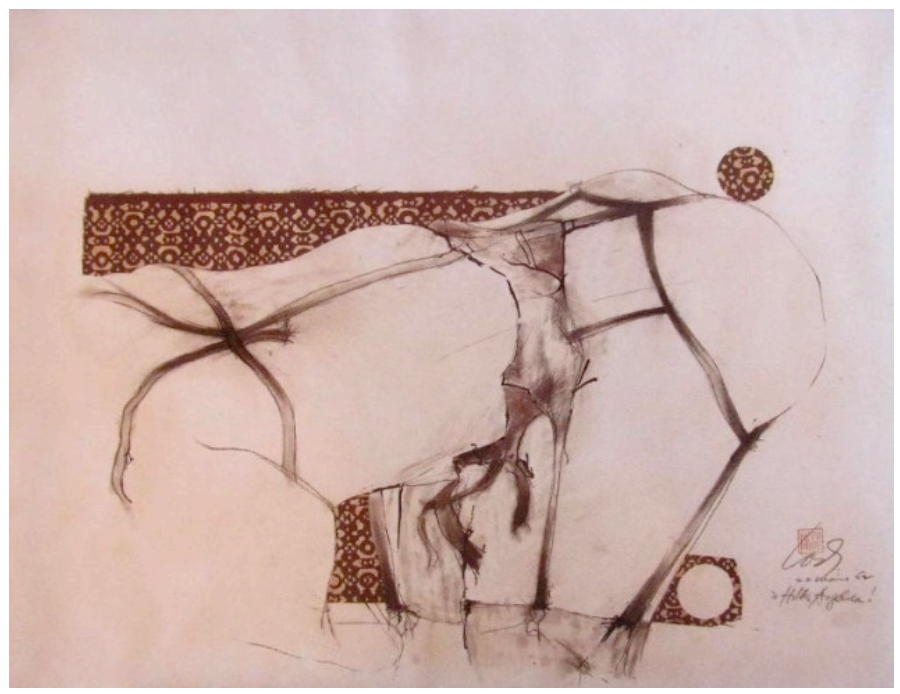

Hilda Angélica

(Wesley Duke Lee, 1962, carvão, nanquim, guache e colagem s/papel, 47,5 x $62 \mathrm{~cm}$ )

Verificam-se na figura 2.2 duas forças tensivas: de um lado, o "querer descobrir" do enunciatário e, de outro lado, o "não querer mostrar" e, ao mesmo tempo, paradoxalmente, o "fazer querer ver" do enunciador, que juntos constroem o objeto erótico.

Nesse caso, se o desejo de descoberta do erotismo plástico, velado, na tela incita o enunciatário a querer descobri-lo, poderíamos, talvez, jogar com os estados intermediários do estatuto erótico: o enunciador ora "faz ver" (da ordem do erotismo figurativo), ora "faz não ver" (poderíamos sugerir aqui uma saturação plástica), ora "não faz ver" (recrudescimento do plástico em relação ao figurativo), ora "não faz não ver" (minimização da plasticidade).

Esse enunciador teria assim maior flexibilidade para transitar entre os termos do quadrado:

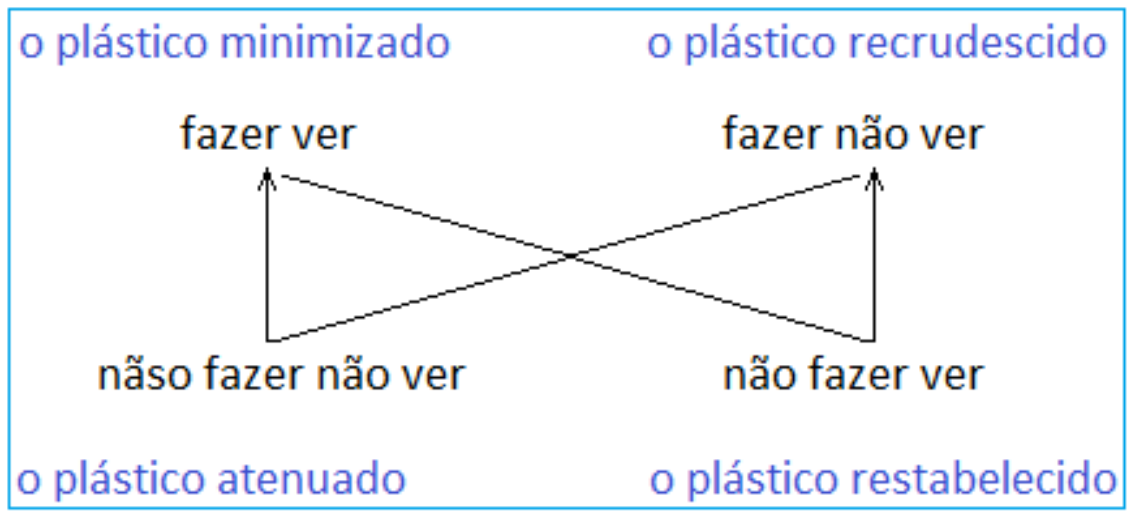


Talvez seja possível diferenciar as sucessivas telas da Série das ligas pelo critério da dosagem relativa dessas quatro posições previsíveis. No entanto, os fazeres desse sujeito da enunciação das Ligas não ocorrem estaticamente, isto é, pode ocorrer essa variação de modalização em telas diferentes, bem como pode ocorrer em uma mesma tela mais de uma modalização. Assim, como teremos oportunidade de explorar adiante, pode haver numa mesma tela um enunciador oscilante entre os "fazeres". Lembramos que não há na Série das ligas nenhuma prancha saturada plasticamente, nem pranchas em que há extinção plástica. Do mesmo modo, também não ocorre o inverso: o figurativo saturado ou a sua extinção. A série opera sempre em pontos intermediários da gradação entre o figurativo e o plástico.

O impulso erótico, que poderia supor também o impulso pela busca da conjunção total dos corpos, estaria, segundo Bataille (2013), propenso ao relaxamento. Dessa forma, nos objetos de ordem erótica a tensão se resolveria pela perseguição de um programa de base de conjunção plena. Todavia, essa conjunção plena não acontece no erotismo, porque é sempre adiada, diferentemente da pornografia, em que há uma rápida superação da falta. No erotismo, embora não haja conjunção, há a permanência do desejo de conjunção (fazer querer ver). Se houvesse a conjunção, o sujeito alcançaria o relaxamento e o objeto de desejo se extinguiria.

No entanto, nas lâminas de Duke Lee o sujeito da enunciação (enunciador e enunciatário) convive com a vontade de suspender as rupturas que afastam o sujeito do objeto, para que haja a apreensão estética de forma intensa. As rupturas são dadas pelas ausências de continuidade (parada da continuação, por exemplo) das linhas, pela falta de um pedaço do corpo, por não encontrar as ligas ou confundi-las com figuras como pelos, virilha, axilas, etc. Evidentemente, o prazer estético é provocado não pela interrupção da cotidianidade propriamente dita, mas pela desaceleração de uma duração mínima, ao longo da qual se flexibilizam as funções de sujeito e objeto e vislumbra-se a possibilidade de plenitude juntiva (TATIT In: LANDOWSKI; DORRA; OLIVEIRA, 1999, p. 198).

De outra forma, a velocidade e o andamento acelerado destruiriam o objeto da ordem do erotismo, pois é no desenvolvimento lento da fruição erótica que o gozo estético propicia ao enunciatário o êxtase da descoberta das ligas, por exemplo; ao mesmo tempo, esse enunciatário quer estar em conjunção com o tempo lento, o da 
demora, porque quer a continuidade desse gozo. Todavia, essa continuidade plena levaria a um total relaxamento, o que não pode haver no objeto estético.

Daí dizermos que, quanto maior a interação ente sujeito e objeto, quanto mais o objeto incita o enunciatário a "querer ver" e a construir o sentido de erotismo indicado nos títulos da Série, maior o prazer estético, maior o erotismo plástico. $\mathrm{O}$ programa narrativo dos objetos da ordem do erotismo é considerar o corpo como algo a ser descoberto, tanto na esfera do figurativo quanto na do plástico; a ideia do desnudamento como descoberta seria uma escolha do enunciador quando da enunciação de seus objetos. O erotismo transita, então, entre o vestir e o despir, por um lado, e entre o figurativo e o plástico, por outro. O jogo se dá entre o contínuo e o descontínuo.

Os enunciadores artistas, às vezes, subvertem os valores de utilitarismo e de procriação do erotismo, transformando-os em valores de busca, de completude, de plenitude e de totalidade, mesmo que efêmeros, como já dissemos. Assim é que a arte torna possível a possibilidade de conjunção instantânea por meio do deleite do sujeito da enunciação (enunciador e enunciatário).

A fruição de uma pintura, por exemplo, tem como base um "acordo" entre enunciador e enunciatário. Como afirma Fiorin (2008, p. 157) "a eficácia discursiva está diretamente ligada à questão da adesão do enunciatário ao discurso [...] $\mathrm{O}$ discurso, ao construir um enunciador, constrói também seu correlato".

No caso da pintura erótica, resumidamente, essa adesão se constrói assim:

\section{O Enunciador quer, paradoxalmente, fazer ver e, ao mesmo tempo, velar o objeto para impedir a conjunção imediata com ele.}

O Enunciatário, por sua vez, quer descobrir, quer desvelar, mas encontra no enunciado artimanhas que Ihe impedem o acesso ao objeto.

Lucia Castello Branco (1984, p. 68), em O que é erotismo, também reconhece os domínios do erotismo sobre a arte:

A expressão artística se realiza em função de um mesmo impulso para a totalidade do ser, para a sua permanência além de um instante fugaz e para a sua união com o universo. A comunicação 
que se estabelece entre obra de arte e o leitor/espectador é nitidamente erótica. O prazer diante de uma obra de arte não é, em primeira instância, intelectivo, racional, embora a razão possa interferir através de julgamentos de valor, apreciações críticas que todo leitor/ espectador termina por fazer. O primeiro contato entre o espectador e o objeto artístico é sempre sensual: aquela obra nos agrada ou nos desagrada, nos "toca", e nos "conecta", ou nos é indiferente.

Em suma, o objeto artístico erótico seria um mediador do prazer, tendo como programa de base a busca de conjunção entre enunciador e enunciatário; o objetivo é o gozo dessa conjunção, uma espécie de gozo estético como fim em si mesmo, a fruição, não estando vinculado a valores utilitários, como em alguns objetos pornográficos, por exemplo.

Nunca é demais ressaltar que a linguagem verbal das lâminas de Duke Lee (tanto nas telas em que o verbal tem função de ancoragem, tanto naquelas em que tem função de etapa) é coadjuvante do erotismo, pois, ao revelar-nos "liga", somos levados a descobrir onde é que no plano visual estão as ligas. Vejamos alguns dos títulos: Série das ligas, Mulher; Ode erótica segunda...; Ode erótica a Lydia. Da mesma forma, produziu uma série denominada Zona; nela encontramos títulos como: A zona: a vida e a morte; A zona: o prêmio; $A$ zona: a parede.

Assim é que o enigma dos textos eróticos suscita o fazer querer estar em conjunção com o objeto até que nos seja possível e, de forma prazerosa, a descoberta de algo, mesmo que mínimo, que possa nos indicar o sentido do erotismo.

\subsection{Enunciação e erotismo}

Como ponto de partida, retomo Da imperfeição, marco das questões estéticas na semiótica, que propiciou um alargamento dos objetos focalizados por ela a partir de então e que, no caso particular das artes plásticas, entende a estética na relação de uma suposta conjunção estabelecida entre sujeito e objeto de valor.

O que vemos na obra de Greimas são análises de textos que evidenciam as experiências estéticas descritas por narradores ou personagens em obras escolhidas de diferentes escritores. Os sujeitos instaurados ora como actantes do enunciado, ora como sujeitos da enunciação enunciada inseridos na obra, tendem a sugerir que a estesia está marcada por alguns traços, isotopias. Os seus exemplos 
são obras literárias em que personagens ou narradores descrevem como sentem um acontecimento, que chamamos de estético.

De fato, as proposições são esclarecedoras quanto aos efeitos de sentido que a estesia provoca em um sujeito. No entanto, esse sujeito ainda é uma construção narrativa de um outro enunciador pressuposto. Nesse caso, o enunciatário e o enunciador a que Greimas se dedica ainda são figuras discursivas do texto a ser analisado. As análises concentram-se no estudo dos efeitos de sentido que os enunciadores enunciam.

Um exame das obras de artes plásticas, picturais ou tridimensionais em que, na enunciação, os enunciadores se utilizam de figuras descritivas de sujeitos que estabelecem uma relação de junção com o objeto ou de arrebatamento por ele produzido, possibilitaria uma análise sobre como se dá a relação estética tanto de um sujeito com um objeto, quanto do enunciador com seu enunciatário. Como exemplo, podemos citar o vasto acervo de pinturas que tratam de "coisas do mundo", referenciando-as em seus dispositivos plásticos, como as pinturas de gênero das quais fazem parte as pinturas históricas, de temáticas bíblicas e mitológicas, de retratos, paisagens, arquitetura, naturezas mortas e, ainda, de cenas domésticas.

Para exemplificar o tipo de análise que esses textos "figurativos" suscitam, escolhemos a figura 2.3, O festim de Baltazar, cuja temática é representada por Rembrandt de maneira minuciosamente descritiva, de acordo com o texto retirado da Bíblia (o artista teria consultado um estudioso judeu para escrever corretamente a inscrição que aparece na tela). Segundo a Bíblia, podemos saber que o que está escrito é: Mene, Mene, tequel, parsim. E o significado dessas palavras é: (1) Mene: Deus contou os dias do teu reinado e determinou o seu fim; (2) Tequel: foste pesado na balança e achado em falta; (3) Parsim: teu reino foi dividido e entregue aos medos e persas.

O texto completo conta que Baltazar, rei da Babilônia, bebia vinho em taças de ouro retiradas do templo de Jerusalém e fazia reverência a outros deuses quando "de repente apareceram dedos de mão humana que começaram a escrever no reboco da parede, na parte mais iluminada do palácio real. O rei observou a mão enquanto ela escrevia. Seu rosto ficou pálido, e ele ficou tão assustado que os seus joelhos batiam um no outro e as suas pernas vacilaram" (Daniel, 5:6). Rembrandt produziu considerável quantidade de obras religiosas e suas interpretações lhe 
trouxeram fama, embora a maioria dos holandeses nessa época fosse constituída de calvinistas que desaprovavam esse tipo de gênero pictórico. Observe-se na figura 2.3 a construção desse tema bíblico.

Figura 2.3

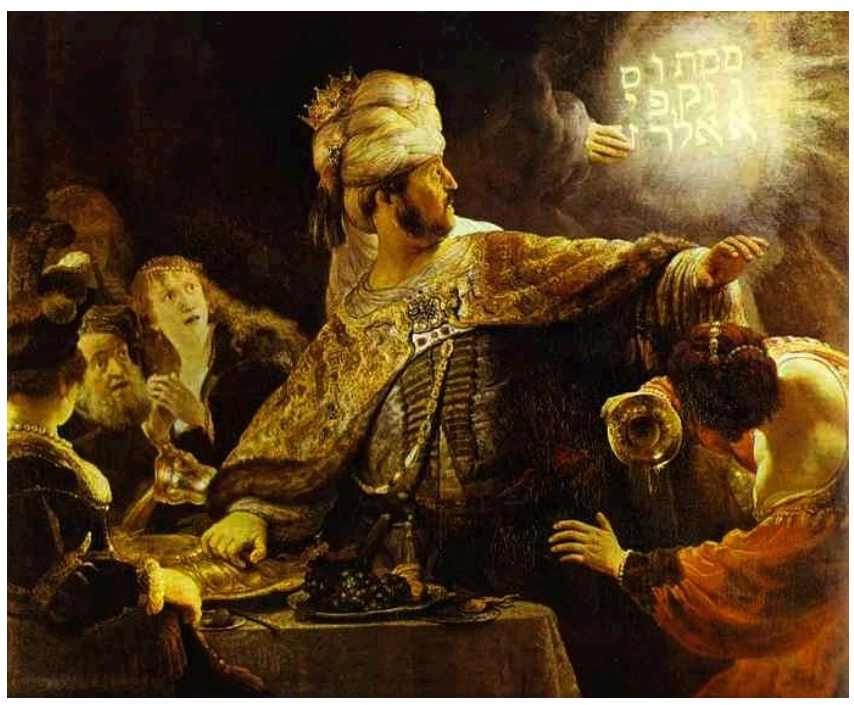

O festim de Baltazar

(Rembrandt, 1635, óleo sobre tela, $170 \times 210 \mathrm{~cm}$ )

Apoiando-nos no texto visual, independentemente do que conta a Bíblia, podemos ter ideia de como o rei Baltazar ficou aterrorizado com esse acontecimento extraordinário. Se olharmos ao redor de sua face, veremos que Rembrandt retratou o instante em que seus olhos saltavam ante a luminosidade ofuscante das palavras que a mão escrevia na parede (palavras que prenunciam que sua morte está próxima).

Diante da cena retratada pelo artista, é possível dizer como o estado de alma de Baltazar proporcionou as ações decorrentes do susto: ele se levanta da mesa num gesto de pavor e, com a mão levantada, se protege do que poderia vir a ser um fato desagradável; a mulher que derrama bebida em sua roupa; o aglomerado de pessoas espremidas ao lado esquerdo do quadro, esquivando-se retraídas pelo susto. Observamos, ainda, que as mãos das personagens estão congeladas em gestos de "ir para..." interrompidos. Normalmente, para persuadir e emocionar o enunciatário, o artista tinha à sua disposição um repertório de signos, pertencentes à retórica, para poder exprimir as paixões; em Rembrandt, temos paixões de susto em seus atores. Na história da pintura, determinados elementos retóricos da linguagem teatral eram incorporados pela "imitação" do pathos na face das personagens 
retratadas. Rembrandt parece usar muito bem estes recursos da retórica visual, como os gestos, o olhar etc. Os pintores, como afirmava Quintiliano em L'institution oratoire (In: LICHTENSTEIN, 1994, p. 105), sabem exprimir tanta coisa sem o auxílio da palavra, porque, como no discurso retórico, pintam com competência os traços do rosto, expressões do olhar, movimentos físicos e outros tantos gestos de um orador eloquente. Assim é que as mãos, nestes gestos de "ir para...", como observamos na tela de Rembrandt, fazem parte da escolha de um enunciador que quer "fazer crer", ou melhor, pelo uso privilegiado da figurativização das fisionomias, o enunciador cria um efeito que substitui o crer e simula "mostrar realmente" o que aconteceu de fato. Como no discurso da Bíblia, em que o que se conta deve "fazer crer" que é verdade.

Além disso, há outro recurso da prática da pintura recorrente nesse período, que é o contraste do chiaro-scuro, muitas vezes utilizado para dinamizar a dramaticidade da cena, tornando-a quase teatral. Outra característica da composição pictórica desse período é o recurso da perspectiva em uma aplicação nada convencional. Vale dizer que o uso da perspectiva foi alterado para criar outro efeito de sentido nas obras seiscentistas: um tipo de recurso que colocava o sujeito da enunciação dentro da história pela utilização de mais de um ponto de fuga em suas composições, que pode estar até mesmo fora do quadro, descentralizando a imagem representada e rompendo com o paradigma classicista da perspectiva única e objetivizada. Veja o esquema abaixo de pelo menos dois pontos de fuga (p.f.1 e p.f. 2): um dentro da tela (p.f 2) e outro que escapa das bordas do quadro (p.f.1).

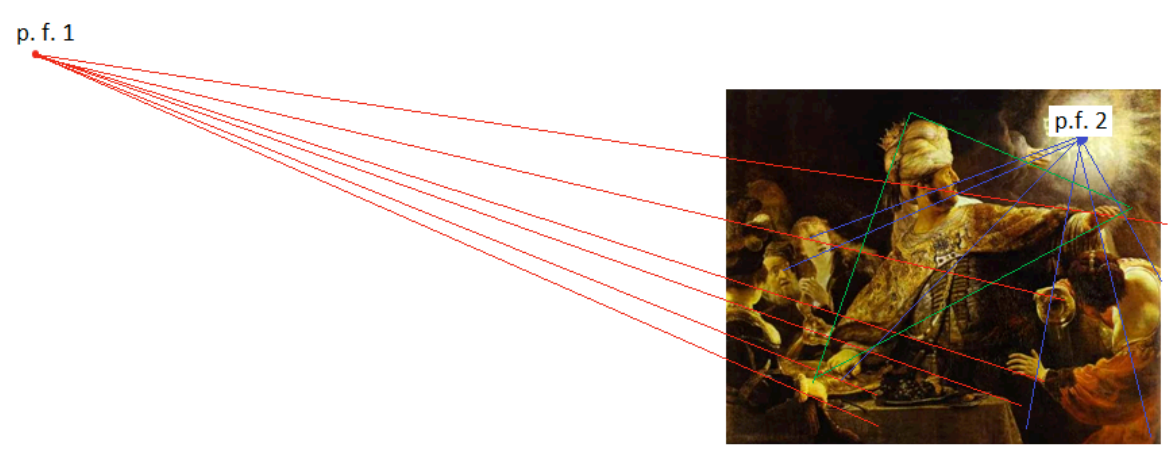

Esquema simplificado da perspectiva em Rembrandt

$\mathrm{Na}$ tela que estamos examinando, o estado de alma de pavor aparece na face de todas as pessoas que compõem o texto. A claridade das palavras molda os efeitos de sentido de relevo e volumes dos objetos, em contraste com as sombras que compõem a cena. 
Normalmente em uma festa deparamos com convidados com alegria, com bebidas, comidas etc., mas não com uma luminosidade surpreendente que infunde terror nos atores.

Se retomarmos Da imperfeição, de Greimas, verificaremos que a suspensão do inteligível e a ruptura da festa criam o mesmo efeito de sentido de deslumbramento do sujeito que em Michel Tournier (Vendredi ou les limbes du Pacifique), quando o protagonista, Robinson, vê a gota d'água voltar para a torneira antes de cair; neste, contudo, o ofuscamento é eufórico, ao contrário de que se passa no quadro de Rembrandt.

Baseando-nos nas questões assinaladas por Greimas (2002 p. 23-30), poderíamos conduzir nossa análise para o efeito de sentido da estesia do rei diante de um fato divino e, a partir dessa proposição, aferir, nas demais pinturas desse gênero, maior ou menor grau de estesia. Notemos que é somente pelo fato de reconhecermos na pintura a figura discursiva de rei (já ancorada no título da obra) e outras que fazem parte da cena de uma festa que a cena se constitui em um acontecimento.

O caso das Ligas de Duke Lee parece-nos diferente; ele nos oferece um objeto que não é uma obra a descrever a relação de um sujeito diante de uma figura feminina em suas vestimentas íntimas. A obra nos oferece uma figura única, composta pela simulação de um corpo feminino parcialmente vestido, ancorada por títulos.

O nosso intento é supor que a enunciação das ligas recria no enunciatário pressuposto, não simulado dentro da obra, a experiência de êxtase estético. $O$ evento estético de fruição de uma obra de arte é semelhante ou igual ao efeito de sentido do sujeito da enunciação das obras que Greimas analisa, mas não imanente ao texto pictural, trata-se tão somente da relação entre a obra de arte e o enunciatário pressuposto, algo que ocorre em presença. Os fazeres do sujeito da enunciação e suas estratégias merecem, nesse caso, particular atenção.

As relações estabelecidas pelo sujeito da enunciação podem ser vistas de duas maneiras nas obras de arte. A enunciação pode ser enunciativa (primeira pessoa), no caso de uma figura cujo olhar se projeta em direção ao enunciatário; ou enunciva (terceira pessoa), como no caso da obra de Degas vista na figura 2.4. Degas fez diversos desenhos em pastel seco, com o tema do banho. Nesse caso, o olhar do enunciador parece-nos marcado na cena posta na tela; o que temos aí é uma 
enunciação enunciva. As figuras das mulheres, em seus desenhos, são flagradas se banhando.

Na cena, porém há uma invasão de um olhar que não compromete a ação das mulheres. Elas estão na particularidade de suas casas em afazeres, a princípio, sem intenções eróticas. O erotismo nessa cena não está indicado pela figura nua representada, mas no olhar pressuposto de um voyeur (enunciador = voyeur) à espreita. As pinturas registram um instante íntimo sem que se perceba a presença do enunciador, o que olha. Mas ele está aí, deleitando-se com o cotidiano feminino.

Figura 2.4

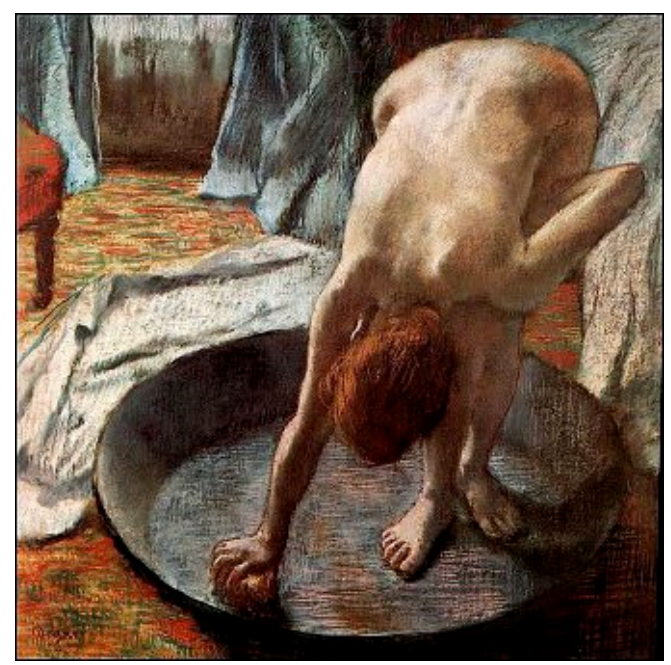

A banheira

(Degas, 1886, pastel sobre papel, 69,9 x 69,9 cm)

Assim como no enunciado verbal, mesmo naqueles de enunciação enunciva, como "a Terra gira em torno do Sol", é possível entender a existência de um eu que diz: "eu afirmo que a Terra gira em torno do Sol”, também nas enunciações enuncivas da obra de arte, é possível depreender um enunciador pressuposto.

No caso das telas da Série das ligas, o enunciador não se revela no desenho por vestir papéis actanciais ou por estar figurativizado. Nesses casos, instaura um voyeur que não se faz ver, porque há uma estratégia que simula um corpo no trânsito de suas vestes; as ligas escondidas pelo enunciador são inscritas num espaço não delimitado. Difícil de detectar um voyeur na posição de enunciador, como em Degas. Nas Ligas, ao contrário, quem veste o papel actorial de voyeur é o enunciatário. Não que, no pastel de Degas, o enunciatário não seja, ele também, um voyeur, mas na Série das ligas este efeito está mais marcado. 
A instância da enunciação pode projetar um objeto plástico mais voltado à substância, enfatizando, nesse caso, a imitação da "realidade" (conteúdo) ou pode projetar um objeto mais voltado aos procedimentos de construção discursiva por meio da criação com as formas (da expressão e do conteúdo). Essa bipolarização é considerada apenas sob um ponto de vista, como já dissemos, de continuidade entre o erotismo figurativo e o erotismo plástico.

Em Duke Lee, podemos verificar tais aspectos e propor dois tipos de análises. O primeiro deles é enfatizar o conteúdo e apresentar critérios para indicá-lo como mais ou menos plástico (o que nos levará a descrever questões sobre o figurativo e o abstrato nas artes plásticas). No segundo tipo de análise, somos mais atentos aos modos de construção, ou seja, à expressão, que diferenciaremos em substância da expressão (tintas, pincéis, bico de pena etc.) e forma da expressão (linhas e manchas).

Como sabemos, os conceitos hjelmslevianos de forma da expressão e do conteúdo e os conceitos de substância da expressão e do conteúdo fazem parte de um sistema que nos permite identificar um objeto que explora mais o universo de uma semiótica plástica ou que explora mais o universo de uma semiótica ocupada em instaurar um simulacro de um mundo natural.

Uma primeira análise seria da enunciação enunciada, que descreve, representa ou apresenta estados de corpos despidos parcialmente e que revelam ou deixam de mostrar aquilo que, só pelo fato de estar insinuado, projeta no enunciatário "um fazer querer ver". Nesse primeiro tratamento analítico sobre a Série das ligas, a veste ou o vestir (trânsito entre o vestido e o despido) será de grande importância para averiguarmos o papel das parcializações e dos procedimentos sinedóquicos que proporcionarão melhor rendimento analítico ao nosso estudo. Como afirma Greimas (2002, p. 85):

[...] A vestimenta, ao mesmo tempo obstáculo e desejo de transgressão, é criadora de um espaço onde o interdito - como em outros domínios - pode plenamente preencher seu papel de instaurador do sentido, onde o imaginário pode se exercer livremente até desenvolver a concepção ocidental de amor. Com efeito, a distância que se estabelece desse modo é, no plano espacial, o equivalente da espera na temporalidade, e esta visualidade imperfeita - ou mais-que-perfeita, porém jamais perfeita - é somente a forma distanciada do tato, tanto é verdade que o tato, a mais profunda das sensações a partir das quais se desenvolvem as paixões do 'corpo' e da 'alma', visa, no final das contas, a conjunção do sujeito e do objeto, única via que conduz à esthésis. 
A vestimenta, figurativamente ancorada nas ligas, descreve um estado e uma ação do despir, mas o faz na construção do plano do conteúdo, a realidade discursiva na obra. Agora, quando se leva em consideração a forma da expressão, como no caso da linha em oposição a outras linhas, isso nos levaria ao segundo tipo de análise.

Salientamos que, nos desenhos inseridos na Série das ligas, além das figuras discursivas apresentadas pelos recursos representativos próprios do universo das artes, a linha desempenha papel actancial. Não importa se a linha contorna uma figura de mulher, mas como ela realiza esse contorno: ela pode ser contínua, descontínua, ser tônica, perder a tonicidade ao longo de todo o contorno.

Esse papel actancial da linha pode ser elevado a um grau máximo de semantismo, como podemos verificar nos estudos de Paul Klee, durante suas aulas na Bauhaus: se a linha fosse pensada gerando um percurso narrativo metaforizado e comparado com a ação de atravessar um rio, nesse caso teríamos traços ondulados e ritmados, por exemplo. Não é que na tela se devam reproduzir os rastros das formas desenhadas pela água na areia, mas que, no domínio da produção do desenho, articulem-se configurações objetivas, como as marcas fluidas da água com linhas que apontam para extensidade do plano visual, por exemplo, prolongando-as em outras direções por sua mobilidade e instabilidade, como na água.

Sabemos que a linha desenvolve-se no tempo e no espaço, o rastro de seu percurso indica os pontos e as paradas; ela completa ou incompleta seu programa de base. Outros artistas, como Matisse, também atribuem à sua pintura características de um espaço sendo invadido por "ruídos" (antissujeitos) que interferem nas linhas que são, em seu destino, a forma. A forma quer ser, pela linha, uma coisa. A coisificação passa pela linha se desenvolvendo no tempo e no espaço e procurando atingir seu objetivo.

O estatuto da pintura, estabelecido por esses artistas, percorre um programa de base que se define como: a linha quer ser forma, que, por sua vez, quer ser preenchida pela cor. Assim, a comunhão se dá: linha - forma - cor - coisa. Mas há variantes durante o trajeto da linha. A linha é o actante que quer ser. Mas existem outras linhas, espaços vazios, manchas, que podem interromper o traçado e contribuir para a incompletude da forma. 
Assim, ao designarmos a linha como sujeito nos desenhos/pinturas da Série das ligas, podemos aferir que a linha, dada a sua constituição, é imperfeita, pois hesita, declina, e a ação que gera a sua linearidade, interrompe seu curso natural. Ela é um sujeito que vai e que, num dado momento, titubeia ir e, ao mesmo tempo, deixa brechas para o espaço se desenvolver. Ela não limita inteiramente. Ela deixa o espaço aberto a corromper.

Duke Lee subverte o programa de base da linha que quer ser contorno, mecanismo de construção de uma figura circundante, como ocorre no Classicismo, por exemplo. Na sua conformidade, a linha se desenvolve como uma baliza entre o dentro e o fora (figura 2.5), figurativamente em seu uso, mas também desempenha papel de "fechamento" quando utilizada como linhas para a construção espacial (figura 2.6). Não vemos estes atributos da linha na Série das ligas.

Figura 2.5

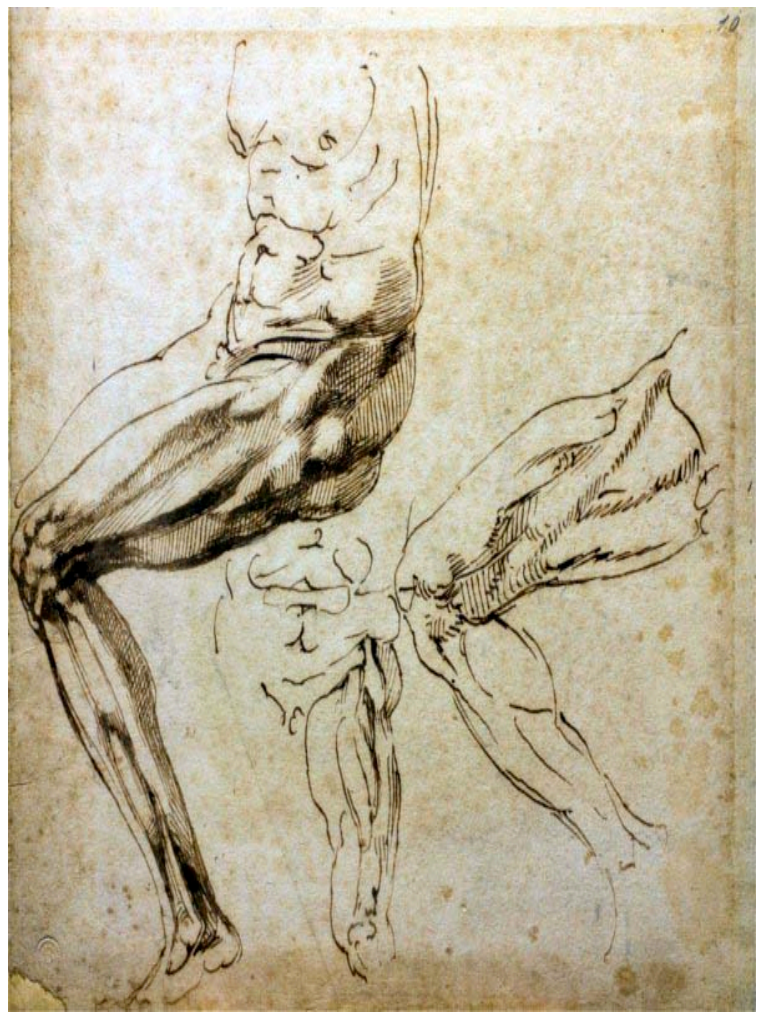

Estudo de perna

(Michelângelo, entre 1508 e 1512) 
Figura 2.6

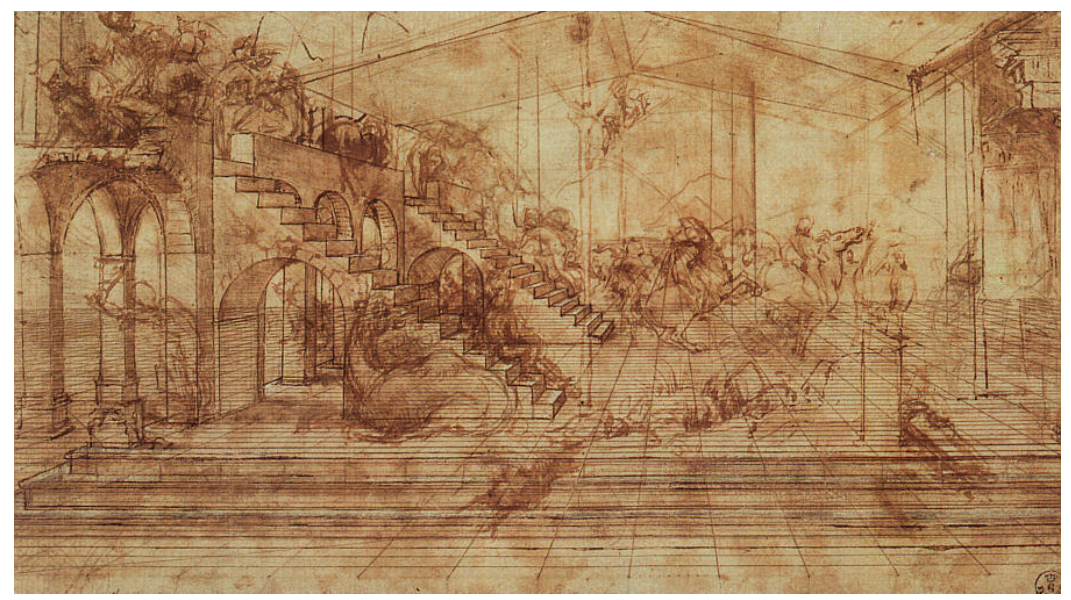

Estudo para a adoração dos reis magos

(Leonardo da Vinci, 1481-1482)

Se a linha desenvolve-se para atingir o estado de "contorno", nas Ligas não ocorre dessa forma, pois o contorno é apenas sugerido ao enunciatário, que precisa recompor e construir "o tempo interno do processo de significação" esboçando uma gramática dos aspectos (perfectivo e imperfectivo, incoativo, durativo, terminativo e iterativo); processo que conduz o enunciatário do objeto estético a pensar em seus próprios campos e em suas próprias traduções (cores e sons, tato e palavra, etc.) nos obrigando a interrogar mais sobre o sensível (FABBRI In: GREIMAS, 2002, p. 98-99).

Figura 2.7

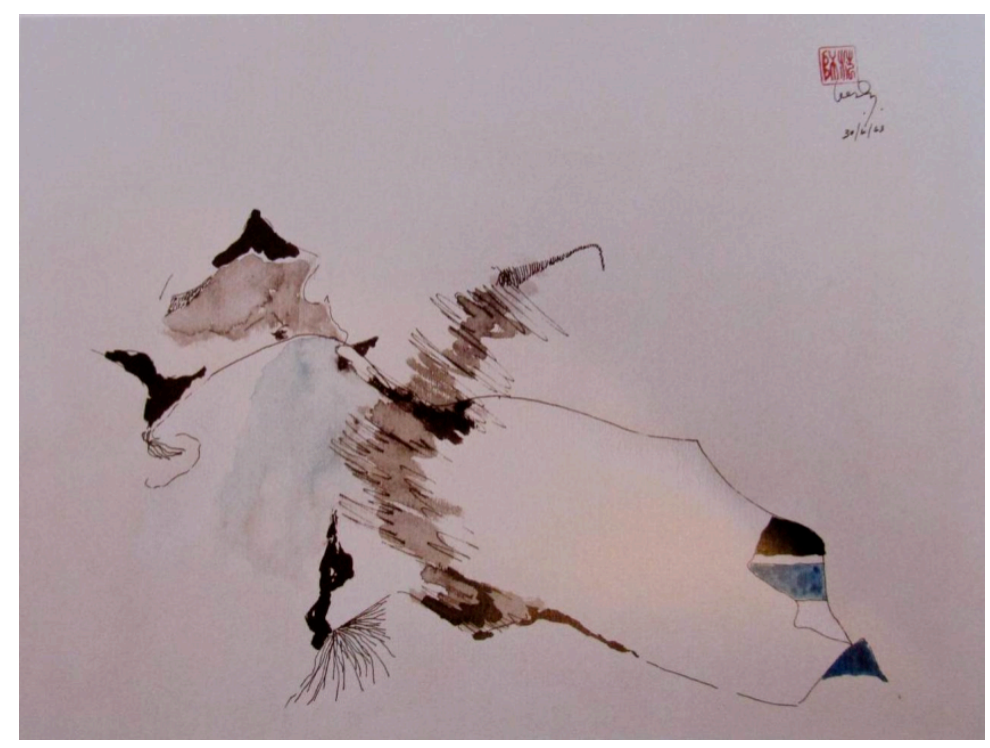

Série das ligas

(Wesley Duke Lee, 1963, nanquim e aquarela sobre papel, 32 × $43 \mathrm{~cm}$ ) 
O curso natural da existência de uma linha é constituir o contorno das formas, o que não ocorre na figura 2.7. Como podemos verificar na tela, o enunciatário é convocado a recorrer ao inteligível para encontrar o sentido. A linha fornece-lhe um ponto sensível que se constitui apenas em sugestão, para que o enunciatário, assuma um percurso para o inteligível. O sensível é porta de entrada para a apreensão do significado, mas sozinho, sem a participação do inteligível, não alcançamos a significação. Evidentemente, isso ocorre em todas as obras visuais; no entanto, o que estamos afirmando é que, algumas delas são mais intensas no sensível, como no caso de Duke Lee.

Aqui, a linha perde as duas funções (do contorno e da construção), para dar lugar ao entorno. O espaço inunda o corpo e amplia o centro de observação. Desconstrói o centro confortável de observação, pois a figura não ocupa um lugar concêntrico conformado objetivamente pelas regras de perspectivas ou pelo enquadramento simétrico baseado em regras canônicas de composição como a busca da razão áurea, etc. A composição está diagonalmente distribuída, o que dinamiza e dá movimento acelerado no sensível, mas demorado no inteligível.

As linhas e as cores em Duke Lee, portanto, em vez de se ocuparem da simulação mimética, interessam-se pela produção do efeito de movimento. $O$ artista explora nelas e por elas aspectos dinâmicos em sua composição pictural. Daí pensarmos em uma associação do erotismo mais ou menos dinâmico, acelerado ou lento.

Além do movimento, observamos também que Lee, explorando a desconstrução das formas acabadas e assim possibilitando que o vazio se faça entrever, garante uma abertura das formas, dos contornos e do próprio espaço, criando uma totalidade englobante. São características que associadas nos fazem percorrer a tela em direções divergentes, simultâneas e dispersas; mais adiante, mostraremos como o erotismo estaria associado a esses estatutos plásticos previstos nas obras em análise.

No capítulo "Semiose das linhas e das ligas" analisaremos alguns aspectos do desenho dessas linhas em relação ao tipo de erotismo que elas possibilitariam. No capítulo 3, veremos como foi possível reconhecer nos fazeres do enunciador as escolhas, tanto da ordem do plano da expressão, quanto da ordem do plano do conteúdo, em que o sensível é convocado pelo sujeito da enunciação, para que, posteriormente, o enunciatário alcance a intelecção da obra de arte. 
ESCOLHAS ENUNCIATIVAS DE EXPRESSÃO E DE CONTEÚDO 


\subsection{Inteligível e sensível em Duke Lee}

Segundo Georg Schmidt, a arte "esforçava-se por conquistar o domínio racional da natureza". No entanto, o que acreditavam ser "domínio racional da natureza" é apenas relativo a um ponto de vista do mundo. É por isso que conseguimos avaliar como certos conceitos transitaram através da história da arte pictórica.

A pintura tinha como objetivo, pelo menos desde o Renascimento até o início da arte Moderna, representar a "realidade sensível", visível, mensurável e "irá inventar meios para criar a ilusão do espaço, do volume e da matéria" (SCHMIDT, 1969 , p. 19). Mas é a partir também da ideia de que o conhecimento da natureza, essa natureza sensível, é função de quem a observa que não vemos propriamente um objeto, mas uma realidade relativa do objeto. Jamais vemos um "espaço" absoluto, mas relativo; não vemos a "cor" do objeto, mas a cor relativa, de acordo com as propriedades da luz que o rodeia.

No entanto, há sempre um "naturalismo" por trás das correntes artísticas, e o que muda é o ponto de vista sobre a natureza das coisas. Além da especulação de que a arte "representa" a realidade, pode-se dizer que ela é um agente transformador "moralizante", tendo assim uma função além da estética.

A crítica da pintura deixou de apenas etiquetar os movimentos artísticos, pois, além das características "naturalistas", poderiam existir no âmago da obra de arte fazeres que estavam a serviço não de uma escola ou cânone, mas a serviço da arte apenas. Assim é que encontramos artistas em que, mesmo que tenham se dedicado a sua arte de maneira mais subjetiva, podemos encontrar algum traço estético referente a "outros tempos" de arte mais objetiva. Dessa forma, um artista neoclássico como Ingres (1870), que produziu uma arte muito próxima do passado renascentista, poderia ser considerado "naturalista" por seus pares.

No final do século XIX, os artistas se deram conta de que pintar era apenas um artifício de representação e que a finalidade da arte não poderia se fixar nos domínios da representação naturalista do objeto. E, cada vez mais, se busca uma 
interpretação particular e pessoal tanto do fazer quanto da enunciação dos objetos artísticos. Os meios de expressão, a partir de então, adquirem autonomia.

O efeito de luz não serve mais para modelar plasticamente as figuras representadas e não mais provoca a ilusão do volume nas obras expressionistas, por exemplo. O efeito de luz, nessas obras, possui autonomia, é independente, não seguindo uma regra baseada no fenômeno físico da luz. Além disso, existe na enunciação o registro da "materialidade" da pincelada (traço da presença de um sujeito enunciador). Não há diferença entre pedra, tecido, pele, cabelo. Os efeitos de sentido que anteriormente eram buscados, como luz e sombra, espaço e volume são secundários ou inexistentes. A anatomia e a proporção, inclusive o próprio desenho, são negligenciados. Dessa maneira, violam-se os cânones da beleza clássica e do "naturalismo". Por isso é que verificamos que a realidade não é tão colorida quanto pintam os impressionistas.

Resquícios dessa inquietação vemos atualmente nas exigências das vanguardas artísticas, cada qual com seus mecanismos de composição, observação e construção. Podemos dizer que foi a partir daquilo que chamamos de modernidade nas artes que se tornou possível tanto para o enunciador quanto para o enunciatário a compreensão de que uma das principais preocupações da arte é a própria arte. Daí ela não mais apenas representar, mas, mais que isso, sugerir.

Ao que nos parece, a toda apreensão poética subjaz um prazer, somado o impacto intelectivo ao impacto sensível, que também não pode ser desprezado tanto na apreensão direta da obra de arte, como também na recepção da crítica.

É por isso que optamos nesta seção apenas por entender a Série das ligas na esfera de uma co-enunciação, importando-nos mais as escolhas enunciativas e o destinador que move o fazer de Duke Lee, bem como a competência do enunciador/enunciatário.

Se uma imagem (considerando os aspectos sensíveis e inteligíveis da pintura e do desenho) proporciona algum prazer, é porque o que se contempla é identificado e reconhecido também por aquilo que se refere ao efeito de sentido de realidade apoiada em uma semiótica do mundo natural: a figura de corpo nu feminino, por exemplo. Podemos notar então que cada objeto pictórico é configurado não apenas pelo fazer do pintor ou do desenhista, mas sobretudo pela ação de um destinador que faz o fazer artístico continuar. 
O desenho isola o colorido e evidencia os contornos da forma da expressão, mesmo que sejam frágeis os limites entre expressão e conteúdo. A delimitação entre desenho e pintura não é apenas um artifício analítico, mas também de deleite, porque possibilita a fruição do enunciatário: o efeito de aproximação ou de distanciamento produz o deleite do desenho ou da pintura. Como sabemos, a fruição é uma somatória: deleite sensível e inteligibilização do objeto, não se podendo separar essas duas áreas.

As etapas do sensível e do inteligível são quase que concomitantes. No entanto, a cor está mais para o sensível, pois ela é puramente substância, trazendo o desenho a forma do conteúdo e da expressão em que nele se deposita essa substância da matéria-cor (SAUSSURE, 1996, p. 80), mesmo nos casos em que a cor transborde as fronteiras das linhas.

Não esqueçamos que foi possível homologar o prazer estético com o termo erótico. É de se notar que o prazer estético, tanto no desenho quanto na pintura, atualiza-se no contrato entre enunciador e enunciatário. Além disso, compreendemos que, mesmo as ligas de Duke Lee sendo a metonímia do erotismo feminino, o que nos importa especificamente é o fazer desse artista, bem como suas escolhas enunciativas, que situam a figura das "ligas femininas" ora sob a configuração mais pictórica, ora mais sob a configuração de desenho.

Se traçarmos um pequeno esboço dos desdobramentos dos conceitos entre a pintura e o desenho ao longo dos séculos, veremos, resumidamente, afirmações como tais: (I) a pintura não se caracterizava pelo desenho, visto que esta seria o gênero comum a todas as artes plásticas; (II) o desenho não seria uma arte e sim "uma técnica cujo exercício está sujeito às condições de um aprendizado escolar" (LICHTENSTEIN, 1994, p. 162).

O desenho atingiu um status de maior prestígio durante muito tempo, principalmente no Renascimento, porque se acreditava que ele é uma atividade "superior" do intelecto e exige um grau de abstração para o ato de construção e imitação do artista. Daí a proliferação de diversos conhecimentos da ordem do intelecto, como a perspectiva, a anatomia, a história e a mitologia para a atividade da pintura.

Sobre a pintura, ao se falar dela, sempre vemos os termos colorido e cor utilizados indiscriminadamente para se referir à mesma coisa. Cor é aquilo que torna 
os objetos sensíveis à visão, já o colorido se refere exclusivamente ao ato de colorir, ou seja, ao ato de pintar.

Há também discordâncias entre os estudiosos e críticos, quando se fala do colorido ou da pintura: afirmam ser uma arte de maior prestígio entre os artistas plásticos, pois é diante de uma pintura (da substância colorida da pintura) que se poderiam captar os matizes e as sombras sutis da figura do corpo humano, por exemplo, iludindo o enunciatário a acreditar que se poderia tocar no quadro para sentir a espessura e a maciez da carne, como se a pintura pudesse ser acessível a outras ordens sensoriais, somando o sentido da visão ao sentido tátil. Por outro lado, para Le Brun (In: LICHTENSTEIN, 2008, p. 43), enquanto a cor satisfaz os olhos, o desenho satisfaz o espírito.

Roger de Piles, em seu Curso de pintura por princípios, publicado em 1708, defende que a pintura deva "surpreender, prender, interpelar, atrair o espectador, dar-Ihe vontade de se aproximar" (In: LICHTENSTEIN, 2008, p. 98-99). Desse modo, o que mais contribui para que haja a conjunção entre o enunciatário e a obra, segundo ele, seria o colorido, a pintura, que seria o objetivo maior do pintor:

"O pintor, que é um perfeito imitador da natureza, dotado de um desenho excelente - como se pressupõe - , deve portanto considerar a cor como seu objeto principal, uma vez que ele só vê essa natureza como algo imitável, que só é imitável porque é visível, e que só é visível porque é colorida. (LICHTENSTEIN, 2008, p. 52)

A princípio, os conceitos pertinentes aos fazeres "pintura" ou "desenho" revelam, na enunciação, que a pintura possui supremacia pelo sensível e, portanto, completamente absorvido o objeto pictórico pelos sentidos; já o desenho seria um exercício técnico, racional e inteligível, útil na construção dos contornos e dos limites percebíveis nos objetos artísticos.

Em outros casos, podemos observar que, na relação entre pintura e desenho, o desenho está contido na pintura (ele é, portanto, englobado por ela, que é englobante), ou seja, o desenho seria o princípio, uma das primeiras etapas, uma das primeiras competências semióticas que um sujeito pintor qualquer deveria ter antes de executar sua pintura. A pintura seria o programa de base de um artista plástico (Cf. GREIMAS; COURTÉS, 1983, p. 354). 
Desenho - pode constituir-se em programa de uso.

Pintura - pode constituir-se em programa de base.

\{Pintura englobante [desenho englobado]\}

Desenho e pintura sempre estiveram em tensão nas discussões de estética e arte. Alguns estudiosos entendem que desenho e pintura não conhecem relação de hierarquia, pois que é possível que o desenho constituía-se independentemente em um objeto estético. Quando se pensa em hierarquia, pode-se dizer que há um plano de base e um plano de uso.

\subsection{Articulação dos meios: o conteúdo da obra de arte}

A arte da pintura e do desenho produz objetos que solicitam da instância da enunciação um trabalho específico com o plano da expressão, composto pela substância da expressão e pela forma da expressão, como sabemos por meio de Louis Hjelmslev (1975, p. 53 ss). Na pintura, o plano do conteúdo foi muito valorizado nas artes de estatuto mimético. Em Duke Lee, no entanto, como temos visto, há uma valorização dos arranjos do plano da expressão.

Sucintamente, a história da arte e da estética tratou do termo "conteúdo" de acordo com visões de mundo que compreendiam desde uma ótica mais materialista e, portanto, mais objetiva, em que o conteúdo era visto como assunto ou argumento tratado na obra, até uma ótica mais subjetiva, em que o conteúdo teria atingido uma esfera espiritualista. Sob esta última ótica, o conteúdo era o sentimento inspirador que acompanhava aquele argumento tratado na "superfície". O sentimento profundo, por sua vez, é causado por um "fazer sentir" que seria o mesmo que "formar conteúdos espirituais". Com outras palavras, poderíamos dizer que fazer arte é formar conteúdo. (Cf PINHEIRO; PANTALEÃO, 2011). Percebemos, então, que a preocupação com a dimensão significativa da obra de arte aproxima as teorias das artes com os aspectos da linguística moderna de Hjelmslev, em que forma da expressão e forma do conteúdo engendram-se para dar sentido.

Não só na teoria, mas também no exercício da arte, vemos tais reformulações, em que "assunto" e "conteúdo" são passíveis de serem entendidos como "formação", "construção". 
Se encararmos, por exemplo, as mudanças do pensamento plástico desde os impressionistas, depararemos com questões que "parecem ser" exclusivas do plano de expressão, como as nuances de cor do pontilhismo. A formulação da teoria das cores de Isaac Newton revelou que a cor-luz branca seria a soma de todas as cores. As cores seriam divididas entre cor-luz e cor-pigmento. O pigmento, por sua vez, é visto apenas porque há luz. Sem luz, não podemos ver as cores.

Pois bem: o artista impressionista diante desse fato criou sua obra com as chamadas cores puras (cores sem adição de sombras) que não eram misturadas na paleta, mas pintadas diretamente nas telas, com pinceladas espaçadas, acreditando que quem as observasse à distância fundiria tais cores perceptivelmente por meio da retina, órgão sensível, formando outras cores e criando também, pela incidência da luz, a sensação de profundidade espacial. Todavia, a luz não pode ser "pintada" e, por isso, é traduzida pelo pintor apenas como uma variante de cor.

O conceito de "pureza das cores" é, mais tarde, redefinido por Matisse, para o conceito de "pureza dos meios" a fim, como afirma o crítico de arte alemão Robert Kudielkaem em Pureza e gênero da imagem, de libertar o fazer artístico da "instrumentalização objetiva pela descrição do mundo visível. [...] Pois os meios de representação na pintura realmente não são meras ferramentas para alcançar um objetivo - atrás do qual elas ficam, no fim - mas, o elemento constitutivo da expressão em si mesma”. (SALZSTEIN, 2009). O próprio enquadramento das figuras era fortemente influenciado pela fotografia, um dos mais novos inventos da modernidade (as primeiras fotografias remontam ao início do século XIX).

Seria a libertação do fazer artístico das determinações secundárias como gosto pessoal do artista ou da mimesis, para atentar-se às próprias exigências das formas do signo. Ou seja, a forma do conteúdo mais a forma da expressão.

Os movimentos de ruptura, a partir do século XIX, segundo seus princípios, primeiramente resgataram valores clássicos e excluíram temas da mitologia e os substituíram por temas da aristocracia e temas históricos; em seguida, substituíram as temáticas aristocráticas pela temática social; posteriormente, a natureza e a paisagem saem do plano de fundo e ganham destaque (citamos, nesta ordem, Neoclassicismo, Romantismo, Realismo, Impressionismo).

Como vimos, em cada um desses novos movimentos artísticos, os artistas, ao escolher seus métodos de composição para os adequar aos temas, fizeram com que a própria execução, os meios e as técnicas de que dispunham se tornassem 
também conteúdo. Ou seja, não é o tema mais importante que a execução da obra, nem a construção mais importante que o tema, mas é a relação entre elas que nos dará o conteúdo da obra de arte.

Esse confronto também é estabelecido nas distinções entre desenho e pintura, como veremos adiante. Assim é que, na obra Série das ligas, encontramos estas particularidades. Quando Duke Lee utiliza tintas como nanquim, têmpera e guache, tais materiais utilizados na expressão também têm sentido em seu plano de conteúdo, fato que pode passar despercebido para um enunciatário leigo, mas não para artistas com quem o autor dialoga. Nesse caso, a técnica utilizada orienta também o sentido.

Vejamos a seguir a importância de alguns aspectos da obra de arte para que se evidenciem tais diferenças também no processo de criação de Duke Lee e como suas estratégias podem ser precedidas por um destinador que nos ajudaria a pensar na produção da Série das ligas.

Em uma época em que os temas e as figuras utilizadas eram impecavelmente pensados, estruturados e arquitetados, não seria possível demonstrar que tal construção se sobressairia aos temas. No século XVIII, por exemplo, encontramos postulados em que princípios de superioridade de determinados "temas nobres" prevaleciam em detrimento de temas menos "interessantes". No entanto, tais princípios, que atingiram grandes críticos e artistas em meados do século XVIII, muitas vezes, já não davam conta de explicar por que um objeto da natureza ganhava maior "interesse" só pelo fato de estar enunciado em um quadro.

Já é possível notar o problema da relação do tema e da execução em Reflexões críticas sobre a poesia e a pintura, de Jean-Baptiste Du Bos, de 1719. Du Bos indaga-nos sobre o que nos chamaria a atenção, durante algum tempo, diante de um quadro: veríamos "apenas a imitação de diferentes objetos que de modo algum nos teriam cativado caso vistos na natureza", ou o próprio objeto "na natureza"? E continua:

[...] quando olhamos aplicadamente os quadros desse gênero, nossa principal atenção não recai sobre o objeto imitado, mas, evidentemente, sobre a arte do imitador. É menos o objeto que retém nosso olhar do que a habilidade do artesão; não dispensamos mais atenção ao objeto real imitado no quadro do the damos na natureza. (DU BOS In: LITCHENSTEIN, 2006, p. 70). 
Aparentemente, a impressão de que os temas e as figuras teriam maior importância era devida ao fato de que no texto visual se agrupavam formas visuais que se assemelhavam, ou davam um efeito de sentido de representação de um mundo "real". O universo "visível" é captado pelo artista e "representado" por ele na tela. O que alguns teóricos mais recentemente discutem é o fato de que os artistas não representam objetos do mundo visível, mas modelam (de acordo com a plasticidade da matéria a que se dedica o artista) com mais ou menos precisão arbitrária, ou seja, a partir de certas convicções subjetivas, através da construção de um mundo perceptivo muito particular.

Sabemos que a pintura, por exemplo, se apropriou de algumas técnicas de acordo com o resultado que elas Ihe propiciaram. Veremos atribuída à tinta a óleo e à sua característica de retardar sua secagem a sua alta performance plástica, propriamente, pois os artistas que a utilizavam conseguiam maior quantidade de detalhes em suas obras.

Seria possível dizer que foi a tinta a óleo que instigou os artistas a pintarem cada vez mais pormenores em suas obras, haja vista a enorme ocorrência dessa técnica desde suas primeiras aparições (século XVI) até os dias atuais. Seria a tinta a óleo responsável por um tipo de exercício sobre a tela que permite uma performance durativa. Por exemplo, utilizando tinta a óleo é possível pintar demoradamente (por semanas, meses) uma obra e, nesse caso, acrescentar detalhes que seria impossível, de outra maneira, adicionar à obra. A têmpera, que era constituída à base de ovo, exigia uma performance imediata e, nesse caso, 0 artista dispunha de pouco tempo para concluir sua obra. A tinta é, portanto, um elemento que determina que tipo de relação enunciativa ocorrerá entre enunciador e enunciatário.

\subsection{Coerções artísticas de estilo e de gênero}

Assim como na "modernidade" a informação adquiriu uma velocidade jamais vista, os acontecimentos, desde o início do século $X X$, têm assumido uma consequente multiplicidade, e, por isso, privilegia-se a fragmentação do indivíduo e dos objetos, de forma mais acentuada nas décadas mais recentes (pós-Segunda Grande Guerra). Essa fragmentação é encontrada nas linhas das Ligas de Duke Lee. Se pensarmos que, para nós, o valor se dá sempre na diferença e que essa 
diferença exige grau de pertinência para alcançar sentido, é preciso que a análise das obras que nos servem de corpus leve em consideração tais diferenças.

Quando um artista está diante de um papel que, normalmente, é branco, retangular e de dimensões exatas e proporcionais (A4, A2, A3 são padrões de tamanho de papel que seguem um grau de proporção entre si: o A4 é a metade do A2, que, por sua vez é a metade do A3 e assim sucessivamente), algumas dessas informações se tornam irrelevantes para ele quando o que lhe interessa não é o suporte no qual o artista desempenhará sua arte ou a relação entre o suporte e a ação nele depositada; no entanto, o artista pode evidenciar esses elementos pelo processo de construção de sua arte, dando ênfase a uma superfície retangular, por exemplo, ou ao fundo branco do papel. Esses elementos podem ou não fazer parte do efeito de sentido que o artista queira dar à obra. Na figura 3.1, é pertinente considerar o fundo branco como participativo nos efeitos de sentido de cor e luz, mas não é pertinente o fundo branco em Goya, figura 3.2.

Figura 3.1

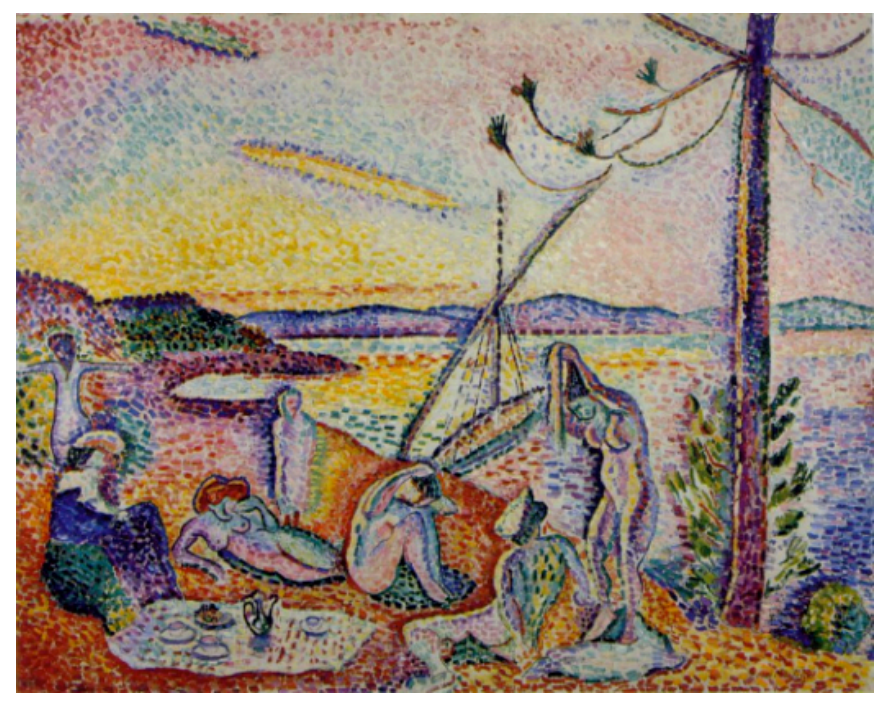

Luxo, calma e volúpia

(Henri Matisse, 1904, óleo sobre tela) 
Figura 3.2

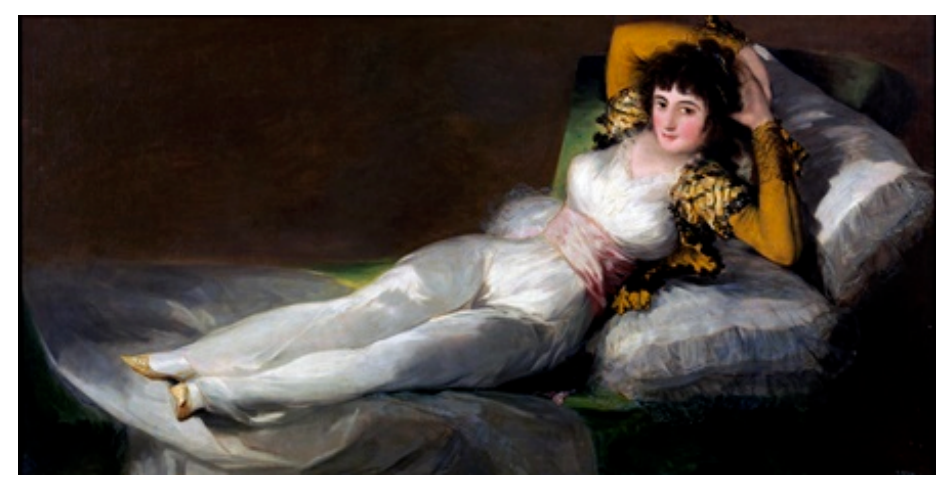

A Maja vestida

(Francisco de Goya, 1802-1805, óleo sobre tela, 95 x $188 \mathrm{~cm}$ )

Na figura 3.1, um pouco do branco não é pintado, é da própria tela. Na análise, precisamos considerar essa opção do enunciador. O branco ali faz parte do recurso pictórico. Já na figura 3.2, toda a tela está pintada; não há resquício do branco (se é que era branca) da tela. O branco que se vê, que constitui efeito de luminosidade e que dá ênfase a partes do corpo da mulher, é resultado da pintura do artista. Nesse caso, fazer referência ao fundo branco é não-pertinente.

Da mesma forma, se considerarmos outros elementos da pintura, como dimensões da tela e material, vamos ter de verificar sempre sua pertinência ou nãopertinência. Por exemplo, em Mira Schendel é pertinente examinar as dimensões da produção artística em suas obras, como a da figura 3.3, cuja tela tem as seguintes dimensões: $47 \mathrm{~cm} \times 22,5 \mathrm{~cm}$. Na tela, um pequeno retângulo escuro (toquinho) contrasta com o tamanho do papel. Ainda há duas figuras na obra de dimensões ainda menores: uma à esquerda do retângulo, e outra na extremidade direita da tela (parecem letras). Nesse caso, a análise não pode desconsiderar o plano da expressão, visto que há uma tensão entre esses elementos que compõem o texto. 
Figura 3.3

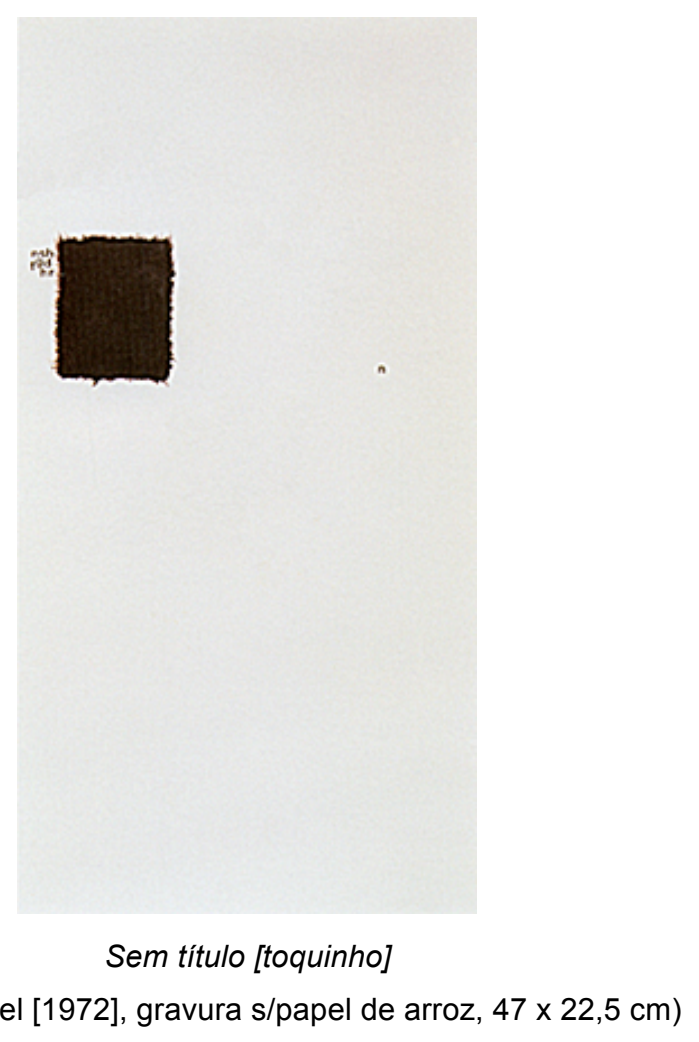

(Mira Schendel [1972], gravura s/papel de arroz, 47 x 22,5 cm)

A utilização do branco do papel como parte integrante do sentido dado ao quadro ou cena representada foi desprezada durante muito tempo. Nas pinturas, assim como nas paredes, o branco sempre foi um elemento neutro que deveria ser colorido com a argamassa ainda fresca (afrescos). O fato de o branco estar ali de nada ajudava o enunciador na constituição do efeito de sentido. A relevância dada ao branco dos "fundos" das pinturas foi objeto dos chamados impressionistas de maneira menos óbvia e, posteriormente, mais evidente dos fauvistas.

Artistas que também foram chamados de pós-impressionistas elevaram o fundo branco a status de colorido (colorido é o ato de pintar). Esses espaços não cobertos pela tinta foram a princípio interpretados pela crítica como falta de talento ou preguiça do enunciador. Mais tarde, artistas consideravelmente valorizados, como Renoir e Monet, criaram estratégias para que o branco fosse incorporado aos elementos figurativos representados (os espaços brancos nas folhagens, deixandose ver, são recursos pictóricos que dão efeito de sentido de luz).

Os impressionistas, como sabemos, tentaram captar o instante fugaz em que a luz se debruçava sobre os objetos a serem representados. Por isso levavam seus cavaletes para fora do ateliê. A partir desse ponto, o fundo branco passou a ter sentido de colorido, de cor. 
Percebemos, ao longo da história da arte, que a cor é um elemento de grandeza inquestionável para a pintura e sua relação consigo mesma é que dá sentido, mesmo quando ela é inexistente. Ou seja, a falta de cor também pode significar. De acordo com o processo evolutivo da pintura, observamos variações nos processos de criação dos artistas diante dos problemas que se criavam a respeito da cor. Em relação à cor, afirma Naves (2007, p. 128):

Por muito tempo a ideia de composição colorística acompanhou a
atividade dos pintores. Ela pressupunha uma continuidade
combinatória entre as cores, de modo a vinculá-las num conjunto
mais ou menos solidário. Foram muitos os recursos mobilizados para
realizar esse intento: do claro-escuro ao pontilhismo, no entanto,
perdurou a noção de uma espécie de substrato, uma Cor Primordial,
capaz de propiciar harmonia a colorações díspares, o que no jargão
da pintura se costumava chamar de "acertar valores". Por esse
procedimento, de fato, a cor transformava-se em coloração. Ao
perder parte de sua materialidade, convertia-se em substância virtual
e cobertura de formas incolores.

Como podemos observar no trecho de Naves, os efeitos de sentido produzidos pela utilização de cores dependem de sua combinação entre si, bem como de sua combinação com outros elementos da obra. Assim como na linguagem verbal um fonema adquire valor em oposição com outro fonema, na pintura, uma cor adquire valor quando se coloca em relação com outra cor. No texto de Naves ainda observamos o uso da expressão cor primordial, que é aquela que não conta com nenhuma mistura. Nesse caso, seu uso implica um acerto de valores (harmonização).

Essas considerações nos levam a ver o artista ocupado de soluções plásticas que nos fazem pensar na arte como uma linguagem complexa interdependente. Cézanne, por exemplo, esperava encontrar algum método que permitisse uma construção plástica vigorosa baseada no que chamava de valores cromáticos puros, sem luz nem sombra (também recursos de simulação de volumes tridimensionais), para fugir dos valores de verossimilhança.

O discurso que a arte assim cria parte do ponto de vista de que a arte deve falar de si mesma. Esse hermetismo do discurso artístico da cor, especificamente, pode ser acompanhado pela observação de obras de artistas plásticos brasileiros, como Eduardo Sued, Paulo Pasta, Cassio Michalany, Renata Tassinari, entre tantos, em maior ou menor grau de elaboração. São especulações próprias da matéria da pintura que regem a orquestração de suas matérias. 
Observando a figura 3.4, verificamos que o efeito de sentido produzido pelo quadro é o de eliminar qualquer relação com a inteligibilização. O texto quer-se apoiar exclusivamente no sensível, nas cores que associa. Se observarmos o pé da tela, verificaremos a existência de uma faixa de cores contrastantes que contribuem para o efeito de sentido. Trata-se tão somente de uma tentativa de eliminar o inteligível, mas sabemos que mobilizados os nossos sentidos, imediatamente eles põem-se como elementos formadores do inteligível. O quadro apresentar-se sensivelmente sem mediações e sem título que o ancore verbalmente, como acontece em alguns casos, cria o efeito de pretensão de a arte desvincular-se da linguagem verbal. Claro que, para tornar-se inteligível para o mundo, tudo o que é capturado pelo sensível passa pelo crivo da língua. Dessa forma, vemos que estão em jogo relações cromáticas entre uma cor e outra. Embora se trate apenas de relações cromáticas, mesmo assim não dispensamos a significação que elas produzem: queremos entender o texto.

Figura 3.4

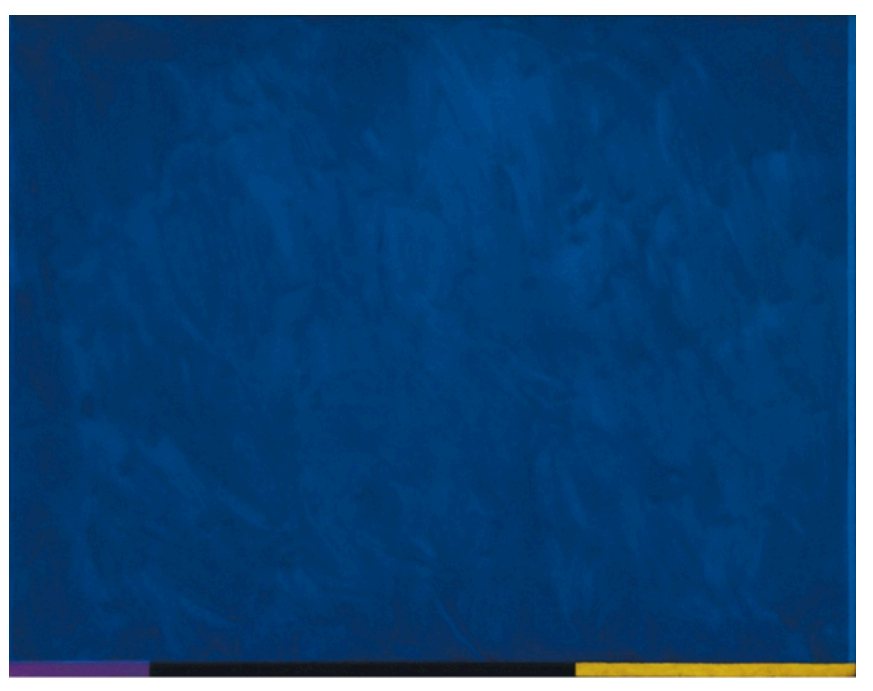

Sem título

(Eduardo Sued, 1988, óleo sobre tela, 64 × $82 \mathrm{~cm}$ )

Na imagem que vemos, a cor azul está distribuída pela quase totalidade do suporte da tela como se fosse um fundo neutro (nesse caso, não mais o branco); seu valor como tal se dá pela existência de uma faixa de cores na base do retângulo. Ora, se não fosse a faixa de cores na extremidade do quadro, os limites entre o que é azul e o que deixa de ser azul não estariam sendo questionados. Mais 
que isso, a faixa de cores no pé do quadro testemunha a identidade do azul e o afirma.

Como sabemos, de acordo com Hjelmslev, o mundo não se apresenta a nós como é; o sujeito é que constrói, pela linguagem, o mundo natural. Seria, portanto, a imanência da forma, o que Saussure entende como valor do signo. A delimitação mútua dos signos plásticos faz emergir o sentido a cada signo da linguagem visual. Ou seja, cada construção textual (no nosso caso, pictórica) dá um sentido próprio pelo recorte dado àquela apresentação do signo plástico cor azul.

A noção de percepção de mundo pelo sujeito coloca o próprio sujeito "como campo perceptivo de presença". É, por isso, que as cores, no caso de Eduardo Sued, estão relacionadas entre si. Diferentemente, porém, das artes impressionistas e pós-impressionistas, em que há uma codependência mútua em que cada cor resvala na outra e, assim, se ajudam a configurar outras tantas, as cores do artista brasileiro, que estão configuradas em diferentes locais topológicos (em cima e em baixo) e eidéticos (formas em relação às faixas de cor), surgem concomitantemente, sem depender uma da outra, mas se valem de diferenças. Enquanto no impressionismo, ao pintar pontinhos de cores diferentes muito próximos, o enunciatário não vê as cores dissociadas, mas uma terceira cor. Pontinhos amarelos e azuis podem produzir um efeito de sentido de verde. O enunciatário colabora para o diálogo entre as cores e suas localizações no espaço pictural.

Nos papéis coloridos de Matisse, ou melhor, papel-pintado (papier-peint), como queria o artista (figura 3.5), o recorte de um azul é o seu limite e, simultaneamente, a afirmação de sua identidade. De fato, os papéis recortados geram colagens, uma não pintura talvez, já que na pintura, tradicionalmente, o artista parte do fundo branco, modela com tinta o espaço e simula a presença das figuras nele construídas.

Matisse procede diferentemente com seus planos coloridos recortados e não modelados. A obra da figura 3.5 é composta de recortes de papéis cujas cores foram tomadas do papel recortado e depois coladas. A cor não tinha sido aplicada ao quadro com um pincel; antes, o enunciador havia previamente aplicado guache em folhas de papel, recortadas logo a seguir por uma tesoura, nesse caso a figura feminina não constituída por pincel, mas resultado do corte da tesoura. 


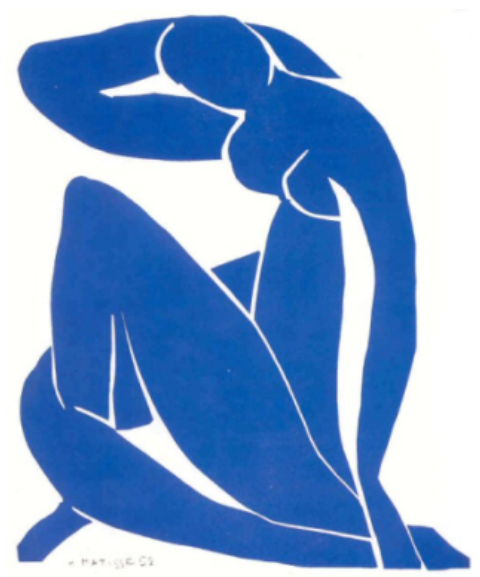

Nu azul II

(Matisse [entre 1950 e 1952], recorte e colagem sobre papel)

Acabamos de ver dois exemplos (Sued e Matisse) de como alguns artistas aplicam as cores nas suas obras e de como a relação das cores entre si, dentro do escopo da própria arte, forma a identidade da cor.

Ao contrário, na Série das ligas, a instabilidade dos contornos dos corpos e a inclusão do elemento colorido apenas em pequenos pontos deslocados dos contornos destitui a dominância da cor e, ao mesmo tempo, dinamiza a cor, que parece buscar a continuidade além dos limites das formas e dos contornos do corpo feminino, deixando-se encontrar significativa existência apenas pontualmente. Basta observar a figura 3.6.

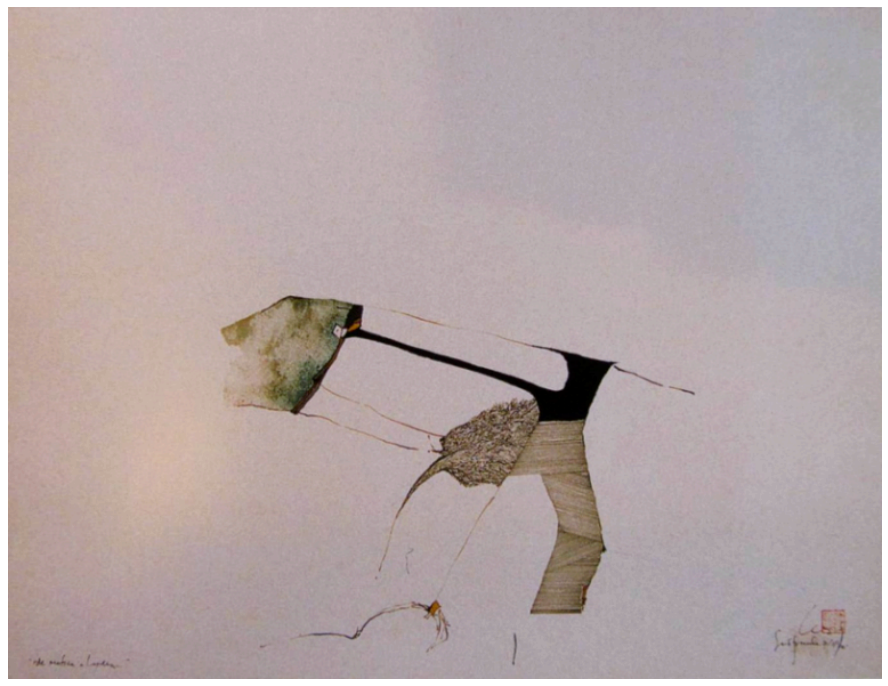

Ode erótica a Lydia

(Wesley Duke Lee, 1960, nanquim e ecoline sobre papel, 48 x $63 \mathrm{~cm}$ ) 
De maneira geral, a cor em sua natureza própria, antes de seu recorte como tal, ataca a retina sensivelmente. Não há propriamente uma inteligibilização da cor. É quase uma pura sensação. Assim, Greimas conclui sua análise de "Elogio da sombra de Tanizaki": "É no plano físico, no nível da pura sensação - as partículas da matéria resplandecendo todas as cores e indo introduzir-se nos olhos -, que se faz a conjunção do objeto com o sujeito [...]" (GREIMAS 2002, p. 52). O sujeito, diante do objeto estético, fica em êxtase.

A tensão criada entre as linhas e as cores, na Série das ligas, é dada pela cor que se apresenta em pontos distribuídos pelo quadro e pela monocromia em sutis matizes (quase transparências), como se incorporasse o branco à sua volta. As formas abertas parecem inundadas pela superfície. A tensão nas ligas é constituída pela presença e ausência da cor, pela presença e ausência da forma.

A cor, por sua vez, não está limitada em formas geométricas que privilegiariam seu estado de cor (a geometria recorta a cor do mundo natural, deixando-a evidenciar-se pela própria natureza material de que é feita), mas é fluida, transparente. Como afirmamos anteriormente, a ausência de limites das linhas e dos contornos são balizas que não demarcam e apenas sugerem a forma e também a cor. Pensar na cor em Duke Lee pode levar-nos a entendê-las como actantes de um texto. Nesse caso, a cor parece-nos, está em trânsito entre o que quer ser, mas o que será já está presente no que quer ser.

O movimento se dá pelo ser da cor em conjunção com o espaço, que invade as formas, ele as contorna. A comunhão entre o fundo neutro e a figura do corpo feminino revela mais as linhas que o entorno ou o interior delas. O "corpo" se dá na busca do olhar em encontrar sentido no emaranhado de linhas que não opõe o dentro e o fora, como no caso das representações das figuras comumente desenhadas. Mas a cor, quando aparece, faz prevalecer o "dentro".

As ligas formam, portanto, um conjunto fragmentado de linha e cor, sem hierarquia, que nos é apresentado como um erotismo que transita entre potência plástica e figurativa, em que cada elemento procura se atualizar, na relação entre enunciador/enunciatário. A seguir, analisaremos como as operações da substância da expressão, da forma da expressão e da forma do conteúdo contribuem para os efeitos de sentido suscitados na Série das ligas. 


\subsection{Efeitos de linha e de cor: entre desenho e pintura}

Esta seção tem como objetivo entender as diferenças entre desenho e pintura de maneira geral. A partir de alguns conceitos pertinentes a estas duas técnicas, traçados ao longo da história, pretendemos esboçar como Wesley Duke Lee, em Série das ligas, faz uso de suas escolhas, que deixam no enunciado rastros ora de desenho, ora de pintura, investigando também como o erotismo se situa nos limiares e limites entre essas duas técnicas.

Abordaremos neste momento as ideias que os tratados, historiadores, críticos e os próprios artistas debateram a respeito da cor e do desenho no interior das teorias das artes. Ora esses debates abarcam mais questões sobre seu exercício, por parte dos artistas, ora questões meramente teóricas dentro de discursos intelectuais, fora do âmbito da sua prática.

Diferenciar desenho e pintura parece simples e óbvio. No entanto, são nomenclaturas para fazeres diferentes que possuem diferentes funções semióticas (HJELMSLEV, 1975, p. 40-41). As definições acerca da pintura e do desenho apontam questões de hierarquias que foram sendo cada vez mais intensas ao longo dos séculos, a fim de que tanto artistas quanto críticos concordassem em determinar qual seria a parte mais essencial da arte de pintar.

Não é de admirar que o homem criasse narrativas mitológicas por meio do desenho e da pintura e, além disso, representasse os dois termos personificados. A pintura, muitas vezes, foi representada na Antiguidade e também no Renascimento como sendo mulher, quase sempre juntamente com uma criança configurada pelo colorido do desenho. Podemos notar nas artes que os termos feminino e pintura já estão ligados desde muito tempo de algum modo. Nesse caso, o feminino da pintura (o sensual e o sensível) está fortemente ligado à ideia de beleza (estética), pelo menos até o Renascimento.

As escolhas enunciativas de um artista quando decide pelo desenho ou pela pintura, de acordo com os materiais de expressão empregados na sua ação (tinta a óleo, aquarela, guache, têmpera, encáustica, afresco), fazem prevalecer na sua decisão determinadas características e atributos tais como a durabilidade e temporalidade. No entanto, sabemos que a escolha anterior à ação do pincel, espátula ou até mesmo golpes de tintas são escolhas paradigmáticas que ainda estão pressupostas. 
A partir de uma ação inicial, o enunciador elimina boa parte das possibilidades de ação diante da obra. No caso dos enunciados plásticos das obras da Série das ligas, podemos apenas supor tais escolhas tanto pela substância da expressão como pelas figuras semânticas depreendidas pela associação dos títulos da obra toda.

O enunciatário pode deparar-se, por exemplo, com elementos expressivos esvaziados de valor semântico, ou cujo valor semântico é constituído pelo próprio plano da expressão. Por isso a apresentação de títulos inseridos em suas telas, justamente para orientar a constituição do sentido. Daí que poderíamos pensar que as escolhas enunciativas de Duke Lee deveriam ser expressas pela coerção das técnicas que ele escolhe. Nesse caso, supomos que o artista na sua linguagem plástica constrói uma metalinguagem, além do erotismo, como temática central.

Alguns tratados de artes plásticas revelam que a pintura deve ser capaz de surpreender, "tocar a alma", provocar prazer estético pela fruição, pelo deleite. E não é por menos que a preocupação dos enunciadores nos modos de representação seja importante, pois são eles também que criam as condições para o prazer estético do enunciatário. Ou seja, se o enunciador escolhe o colorido ou escolhe o desenho, ele está pressupondo que o enunciatário receberá de forma diferente cada uma das técnicas escolhidas.

Como sabemos, as obras da Série das ligas de Wesley são elaboradas com materiais diversos, o que justifica nosso intento em diferenciar os efeitos de sentido que cada um proporciona:

(I) o grafite, giz pastel e carvão são materiais que nos dão um efeito de sentido de desenho: são bastões rígidos que riscam a superfície rugosa da folha de papel;

(II) o nanquim, o guache e o betume dão efeito de sentido de pintura, já que são fluidos e absorvidos pelas cerdas de um pincel que espalha suas partículas pelo papel.

Nas ligas, vemos a interdependência desses materiais, contribuindo para um jogo de forças entre a plasticidade das tintas e o refinamento da arte do desenho. É como se, mesmo se dedicando a matérias mais maleáveis e de menor grau de condução, como o guache e o nanquim, por exemplo, o desenho de Wesley ainda 
assim fosse minucioso, preciso; nesse caso, mostra-se um enunciador competente, visto que manipula com facilidade o colorido da aquarela que se deita no desenho.

A maleabilidade das tintas fluidas depende das ranhuras e rugas da superfície do papel para ser absorvida com mais ou menos precisão, dando em cada caso um efeito de sentido sensível diverso: para cada substância, um tipo de efeito. Dessa forma, as linhas de contornos dos corpos na Série das ligas podem estar mais para um efeito de sentido de pintura, quando há o uso de veladuras e betumes, tornando as linhas mais esparsas, fluidas e coloridas ou podem estar mais para um efeito de sentido de desenho, quando as linhas formadas são monocromáticas, retilíneas e contínuas, bem como pelo uso de materiais sólidos.

\subsection{Semiose das linhas e das ligas}

\subsubsection{A linha}

Um conjunto de pontos dispostos sequencialmente forma a linha. A menor parte de uma imagem construída é o ponto. O ponto é o lugar onde tudo começa, pela inércia ou pelo exercício. Mas é pela linha que tudo se desenvolve.

Seguindo esse raciocínio, o ponto é um instante, é desprovido de duração, é aspectualmente incoativo. É o início do ato criador. Esse é o momento em que o artista entra em conjunção com a criação. Assim como o deus de Michelangelo estica seus dedos para tocar os dedos de Adão: criador e criatura no instante da criação (ver figura 3.7). Tensão entre dois momentos que são um só. Deus parece ir em direção aos dedos da criatura, que parece ainda relaxada e sem forças. $O$ espaço entre eles é o instante instável anterior à vida.

\section{Figura 3.7}

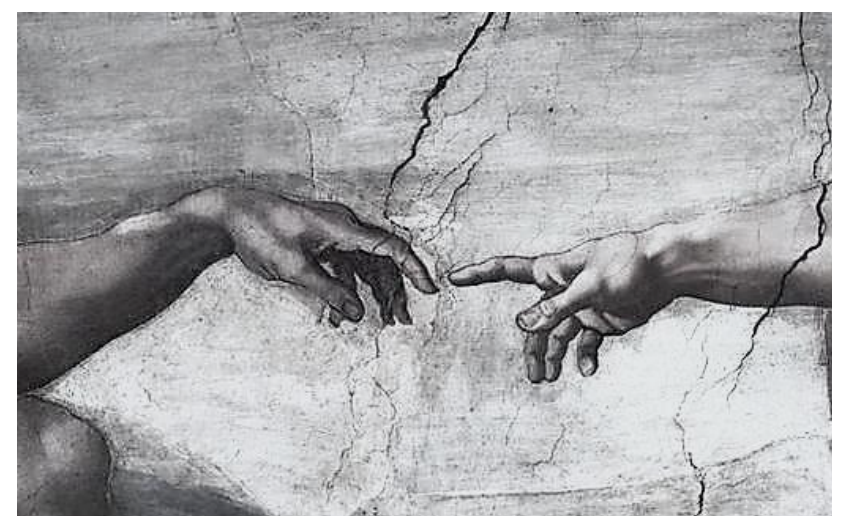

Detalhe de A criação de Adão

(Michelangelo, 1508-1512) 
A linha, por sua vez, possui dimensão única, se desenvolve no tempo, recorta o espaço e o divide; temos, de certa forma, por meio da linha, proporcionalidade entre tempo e espaço.

Os aspectos formais das linhas podem conduzir a formação de planos; há também a relação de planos, que seria um aspecto da linha percebido formalmente; outro exemplo é uma linha que divide o espaço retangular do quadro ao meio, na horizontal, de forma retilínea ou mesmo curva. No entanto, se a essas linhas descritas Ihes atribuíssemos um adendo verbal, como um título, poderíamos dizer que o objeto configura um horizonte cheio de montanhas, por exemplo.

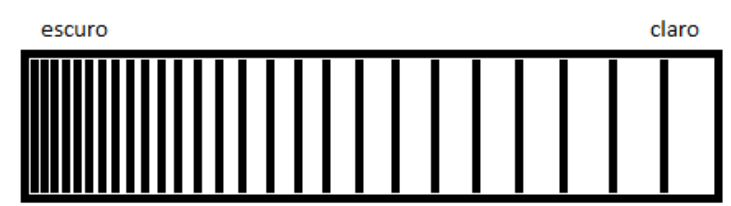

Claro-escuro

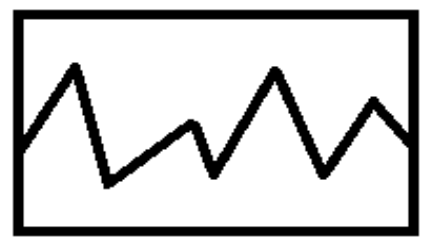

Figura e fundo

A linha pode ser contínua, reta, curva, cheia de pausas, composta por respiros, intervalos. A linha pode ser forte, frágil, discreta, nervosa. Ela pode adquirir as paixões de alma de seus enunciadores, conforme se dê o registro de suas ações nas telas pictóricas, nos desenhos etc.

Se fizermos uma comparação entre o traço fluido da aquarela e o traço feito pelos artefatos sólidos, encontraremos inevitavelmente definições que pertencem ao mundo dos elementos químicos e suas relações físicas de atrito e contato entre moléculas. No nosso caso, o que nos interessa diretamente são as relações sensíveis que produzem em um primeiro instante um impacto no enunciatário.

Podemos afirmar que os traços feitos pela tinta de uma aquarela são pouco direcionados, pois tudo que é fluido tem direções não tão previsíveis; são apenas iniciadas pela mão do artista que garante um mínimo de domínio sobre o desenvolvimento linear do traço aguado; isso tudo por causa também das ranhuras e asperezas do papel, que dificultam ainda mais a certeza do traço. Daí começarmos a pensar na relação da substância plástica conduzindo diversos recortes formais. Mas, segundo Saussure, tanto substância quanto forma são interdependentes. No momento, deixemos no ar essa questão. 
As mãos mais ou menos precisas podem conduzir o instrumento que agride e risca a superfície: um flagrante do fazer artístico. Cada tipo de linha possui características próprias e únicas de seu enunciador, seu idioleto, como na caligrafia, sendo possível fazer uma analogia com a impressão digital do artista, se é que podemos assim definir.

Outro aspecto encontrado na série de Duke Lee é a fraca acentuação contrastando com pequenos instantes tônicos, que se pode ver na figura 3.8. Nos pontos em que o pincel descansa, a cor ganha forte tonicidade; quando o pincel corre, temos uma baixa tonicidade no traço que pode até mesmo sumir, desaparecer. A velatura, um recurso utilizado para amenizar a acentuação, é a superposição de uma camada fina e tênue de tinta opaca ou transparente de tons mais escuros sobre tons mais claros, que permite que a cor do fundo permaneça quase inalterada. Pode ser feita pela utilização de betume ou tinta a óleo.

Figura 3.8

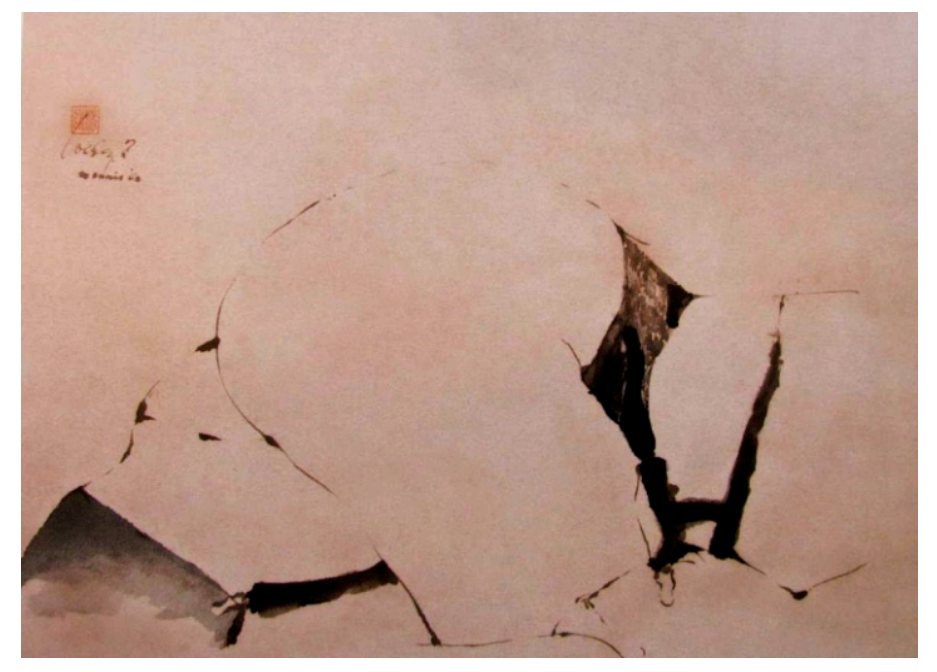

Série das ligas

(Wesley Duke Lee, 1960, betume e aquarela s/papel, 45 x $60 \mathrm{~cm}$ )

A tinta, portanto, está no limiar do espaço e do tempo. Ela flui, é emissiva (ZILBERBERG, 2006, capítulo 4), enquanto uma linha feita com grafite ou giz pastel possui caráter aspectual incoativo, tendo logo seu rompimento ao longo do percurso. A linha é sólida, mesmo que interrompida ou tracejada. Assim, o sólido cria barreiras, limites. 


\subsubsection{A tonicidade das linhas}

Selecionamos na figura 3.9 quatro imagens retiradas da Série das ligas:

Figura 3.9
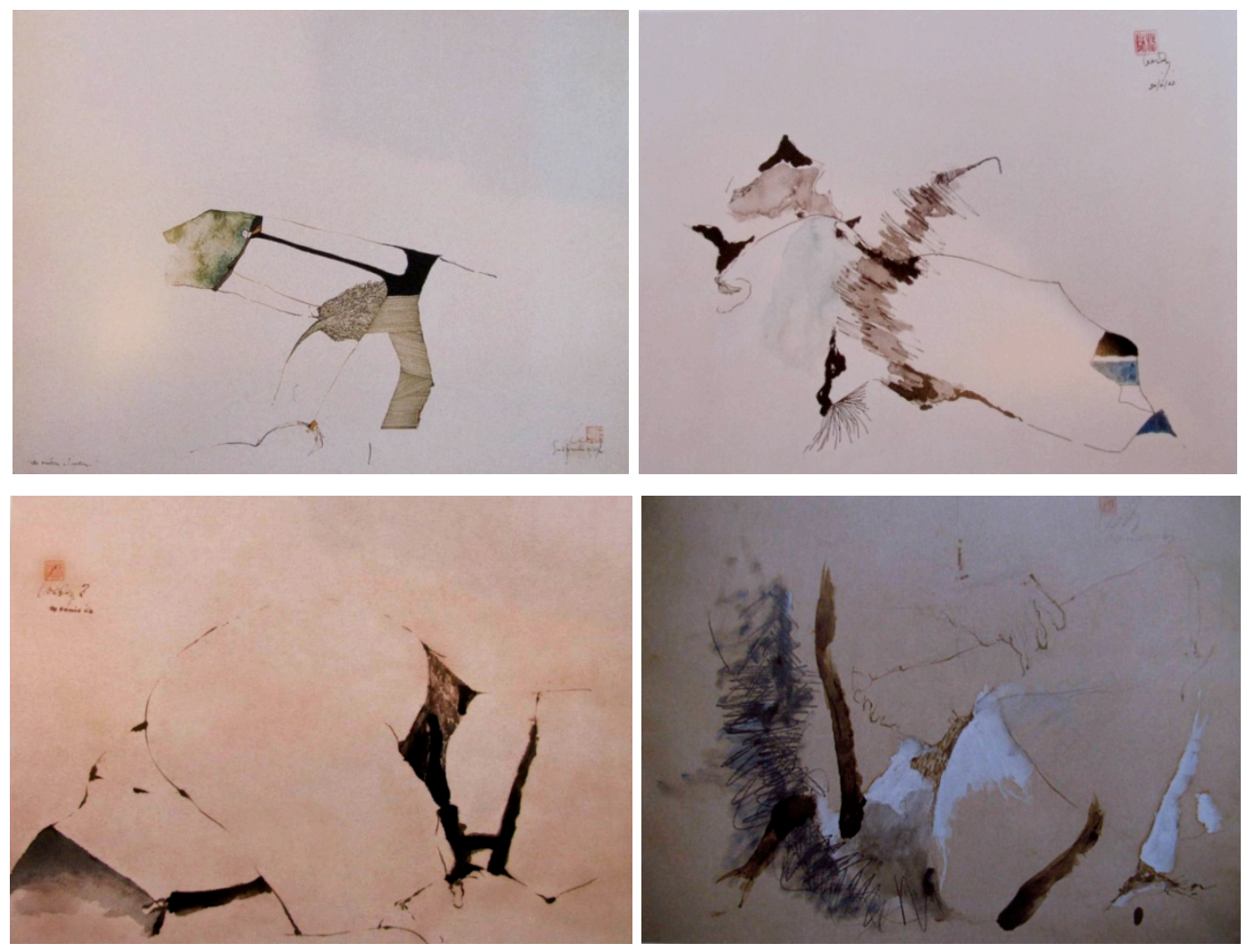

Conjunto de quatro Ligas de Wesley Duke Lee

Nas artes plásticas, o enunciatário pode deparar-se com obras figurativas, densamente semânticas ou com obras não figurativas, cujo valor é constituído pelo próprio plano da expressão. Nesse caso, não é incomum o uso de semiótica verbal com função de ancoragem. De certa forma, as legendas que aparecem na obra Série das ligas têm também uma função não só de orientação de leitura, como também de buscar um efeito de proximidade com o enunciatário; o enunciador estende a mão a seu enunciatário e o conduz ao caminho do sentido. Doutra forma, sem as legendas, ele poderia sentir-se perdido, sem dar-se conta de que se trata de um objeto erótico; em vez de ligas, poderia ler "montanha", "mato", etc.

Na Série das ligas, podemos estabelecer relações entre os elementos do plano de expressão (linhas, manchas de cor) e do conteúdo (ligas, corpo feminino) e encontrar valores tensivos que caracterizam a escolha enunciativa de Duke Lee. 
Analisando o conjunto da obra da Série das ligas, reconhecemos parcialmente as figuras discursivas de ligas femininas. As ligas assumem papel central, porque os títulos de Duke Lee induzem ao reconhecimento dessas figuras. É pela utilização dos meios verbais que se dá a compreensão dos objetos picturais, sejam eles desenhos ou pinturas.

Quando o enunciador coloca "ligas" no título de sua série, ele cria no enunciatário a expectativa de encontrá-las no texto pictórico. As ligas, bem como as partes do corpo feminino, constituem-se em metonímia de uma mulher, e é na relação dos traços dessas ligas com os traços do corpo feminino que o valor erótico se dá, pois esse valor não está exatamente nem nas ligas, nem nas partes do corpo, mas na construção do enunciado.

Em algumas lâminas, a figura feminina distancia-se da representação mimética, deslocando-a para um universo estético próprio da matéria da pintura. Os traços vão, ao longo da série, perdendo a referência do mundo natural do corpo feminino que aparece incompleto, causando-nos um estranhamento.

Em Wesley Duke Lee, o sentido estético sobrepuja ao sentido puramente ilustrativo e utilitário do corpo feminino. Ora, além da possibilidade de projetar sobre o corpo humano conotações estéticas, "há também a possibilidade de, por meio do discurso, criar um efeito de sentido em que, aparentemente, o corpo é construído esvaziado de conotações" (PIETROFORTE, 2004, p. 27), como no caso dos livros de biologia e dos manuais de anatomia. Além das conotações científicas, são projetadas no corpo, a depender do contexto, conotações sociais, místicas e religiosas. O sentido utilitário que citamos pode ser observado na tradição cristã que privilegia o "espírito" em detrimento do corpo, que assim é destituído de necessidades, desejos e impulsos, enfim um corpo imaculado, restando-lhe apenas a função utilitária e prática da reprodução da espécie. Nas artes em geral o nu possui apelo estético e não apenas ilustrativo e utilitário.

Os cortes das figuras não são estabelecidos com base na anatomia humana; não configuram, portanto, partes mutiladas de um corpo. A incompletude do traço, antes que manifestar uma disforia, revela uma posição do enunciador diante do seu fazer artístico. Ele quer um fazer erótico e sabe que para isso precisa mutilar o discurso das linhas.

Esse corte oblíquo é feito pela escolha enunciativa de ruptura da continuidade das linhas que extrapolam os limites das bordas do quadro. Como estamos 
verificando, em Duke Lee é importante o espaço além das molduras, que o espectador-enunciatário é obrigado a imaginar para fazer uma ideia da completude dos corpos (figuratividade). Nesse caso, temos a convocação da intervenção ativa do enunciatário.

Se assumíssemos a característica da extensidade da linha, ela seria livre, fluida, ininterrupta, sem qualquer elemento remissivo que a interrompesse, formando um corpo completo, explícito. Na série que estamos examinando, não há contorno definido das formas da expressão. O seu percurso é interrompido pelas pausas incessantes da mão do artista, que podem ser observadas nos ângulos das articulações e dobras do corpo feminino representado, como podemos observar na figura 3.10:

Figura 3.10

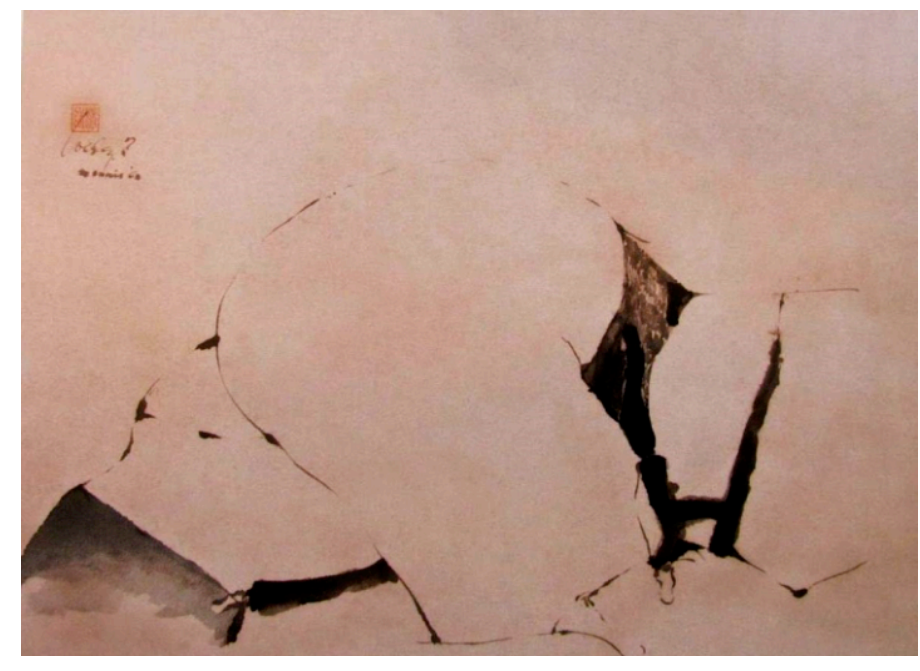

Série das ligas

(Wesley Duke Lee, 1960, betume e aquarela s/papel, 45 x $60 \mathrm{~cm}$ )

Enquanto a tinta descansa sobre o papel, criam-se manchas pontuais marcadas pela absorção das rugosidades do material, demarcando muito nitidamente essas pausas: trata-se aqui dos limites da substância que influenciam na forma de expressão e conteúdo. As linhas, muitas vezes ou na maioria delas, descrevem uma trajetória não retilínea: tracejada, torta, sinuosa, curvilínea...

Ao longo dos traços que compõem cada corpo, percebemos que a fraca acentuação perde lugar para a alta tonicidade em determinados pontos estratégicos com o uso das tintas e das cores. Voltando à figura 3.10, vemos uma saturação do preto em determinados pontos do quadro. Parece-nos que o artista nos faz ver as 
ligas pela maior quantidade de tinta e pelas cores utilizadas. Nesse caso, as linhas se tonificam e as ligas emergem da figura.

O acesso ao sentido dá-se, antes de tudo, pelo sensível do enunciado. O uso, na maioria das vezes, de transparências (betume, aquarelas) monocromáticas é surpreendido ou pela força da cor ou pelo traço grosso que configura as ligas. Todo o resto fica "transparente", atonizado. As linhas dos contornos sutis do corpo apagam-se ainda mais e o que nos chama a atenção é o preto do nanquim, o traço grosso do giz pastel e a pincelada enérgica do betume, de acordo com cada material empregado no papel.

São esses traços pictóricos, essa pincelada enérgica que pode, ao enunciatário, revelar o éthos do enunciador artista. Em outras telas, os traços significantes são manifestados de forma menos intensa, o que permite que um enunciatário reconheça um enunciador que oscila entre momentos de maior e menor contenção, que, ajuda a construir um éthos que pretende ser múltiplo, versátil, que perambula pelo betume, pelo guache, pelo nanquim, pela colagem, pelo xerox, enfim pelos mais diversos materiais.

Assim podemos reafirmar que o erotismo não está necessariamente na percepção e no reconhecimento das ligas, figurativizadas, mas, mais que isso, está na relação entre a tonicidade do traço e a atonicidade da linha, concernentes à percepção e ao reconhecimento das ligas.

Aqui, há um jogo em que o enunciador oferece: (1) o mostrado e (2) o sugerido, com os quais ele pode criar uma correlação inversa entre a maior/menor definição do que o enunciatário vê nas telas e o que ele mesmo, enunciatário, é capaz de completar mentalmente.

\section{Linhas tônicas $=$ ligas emergentes \\ Linhas átonas $=$ ligas veladas}

É por meio do efeito de sentido de proximidade (intimidade) ou distanciamento do enunciador/enunciatário diante das ligas que podemos entender um pouco o jogo entre o sensível e o inteligível na Série das ligas.

Quando o efeito é aproximado, perdemos os limites extremos da forma. No entanto, não há qualquer artifício técnico para a construção de uma profundidade 
objetiva (perspectiva); o que convoca o enunciatário do objeto é a incompletude deste. Quanto mais nos aproximamos de um objeto, menos somos capazes de vê-lo na sua completude. O fato de Duke Lee pintar em close-up uma parte e esconder o restante simula uma maior proximidade do objeto. Nesse caso, o enunciatário está muito próximo da região erótica do corpo feminino. O distanciamento e a proximidade, puramente efeitos de sentido, também são verificados pela presença dos traços que se assemelham aos pelos pubianos, figuras recorrentes em todas as lâminas analisadas, aproximando o enunciatário da obra de arte.

Resumindo, teríamos:

Proximidade do enunciatário - mais sensível, mais impactante, erotismo plástico; tônico, portanto.

Distância do enunciatário - mais inteligível, menos impactante, erotismo figurativo; átono, portanto.

Quanto mais efeito de proximidade, mais o enunciado das telas estaria no eixo do sensível, porque nos "chega" primeiro sensivelmente aos olhos (eixo da intensidade: o impacto do êxtase segundo Zilberberg, 2011); quanto mais efeito de distância, maior a quantidade de traços significantes representativos do corpo feminino; portanto, mais inteligível (eixo da extensidade).

Em Duke Lee, na enunciação das Ligas ocorre impacto, susto, pela ruptura de isotopias do erotismo do corpo feminino nu. O fato de os significantes plásticos não se equivalerem a traços referentes à figura do corpo feminino e não serem facilmente reconhecíveis apenas sugere as figuras eróticas e, por isso, o enunciatário precisa buscar a conjunção entre ele e o objeto; um precisa do outro, para que a experiência estética seja alcançada.

Assim, o enunciatário apreende o objeto, bem como também se sente tomado por ele. Seria, portanto uma das questões referentes ao "estatuto do objeto enquanto actante pressuposto pela experiência estética" (LANDOWSKI In: GREIMAS 2002, p. 150). Ou seja, a apreensão estética pressupõe a presença do sujeito participativo para a compreensão do significado nas artes visuais. Greimas 
(2002, p. 30), a respeito da apreensão estética, tomando como exemplo o romance Sexta-feira, de Michel Tournier, afirma:

\begin{abstract}
A inserção na cotidianidade, a espera, a ruptura de isotopia, que é uma fratura, a oscilação do sujeito, o estatuto particular do objeto, a relação sensorial entre ambos, a unicidade da experiência, a esperança de uma total conjunção por advir, esses são os poucos elementos constitutivos da apreensão estética que o texto de Michel Tournier nos revelou.
\end{abstract}

A respeito da obra de Greimas, Da imperfeição, podemos reconhecer que varias características da estesia apontadas por ele podem ser aplicadas no texto pictórico. Em resumo, a estesia caracteriza-se pela brevidade do acontecimento que resulta nas rupturas e quebras.

Assim é que o eixo da intensidade se apresenta inversamente proporcional ao eixo da extensidade. Da mesma forma, o impacto da fruição das obras da Série das ligas se ajusta a essas questões, como apontamos no quadro explicativo acima, já que o efeito de sentido de proximidade se dá pelos recursos pictóricos de incompletude das linhas e, em um segundo momento, pelo requerido contrato entre o enunciador e o enunciatário na construção do sentido erótico discursivo.

A correlação do eixo da intensidade e da extensidade pode ser conversa ou inversa. Se inversa, temos uma tonicidade alta na intensidade e concentração na extensidade, como nas telas de Lee, pois ele concentra e intensifica o sentido; se conversa, temos uma tonicidade alta, bem como uma difusão que se dá pelo máximo de extensidade, como podemos ver na tela de Goya "O fuzilamento de 3 de maio de 1808" (figura 3.11).

Nela, existe um grupo pintado de frente e outro grupo pintado de costas. $\mathrm{O}$ grupo de fuzileiros é uma massa unifome de braços, pernas e fuzis. O povo é visto de frente; em alguns vemos uma expressão de pavor e em outros, de resignação. As áreas mais claras do quadro são iluminadas pela lamparina que está no chão, ao centro do quadro. Essa mesma luz dá ênfase ao homem do centro, de braços erguidos, que veste uma camisa branca e uma calça amarela, de mesma cor da lanterna. Observemos a tela: 
Figura 3.11

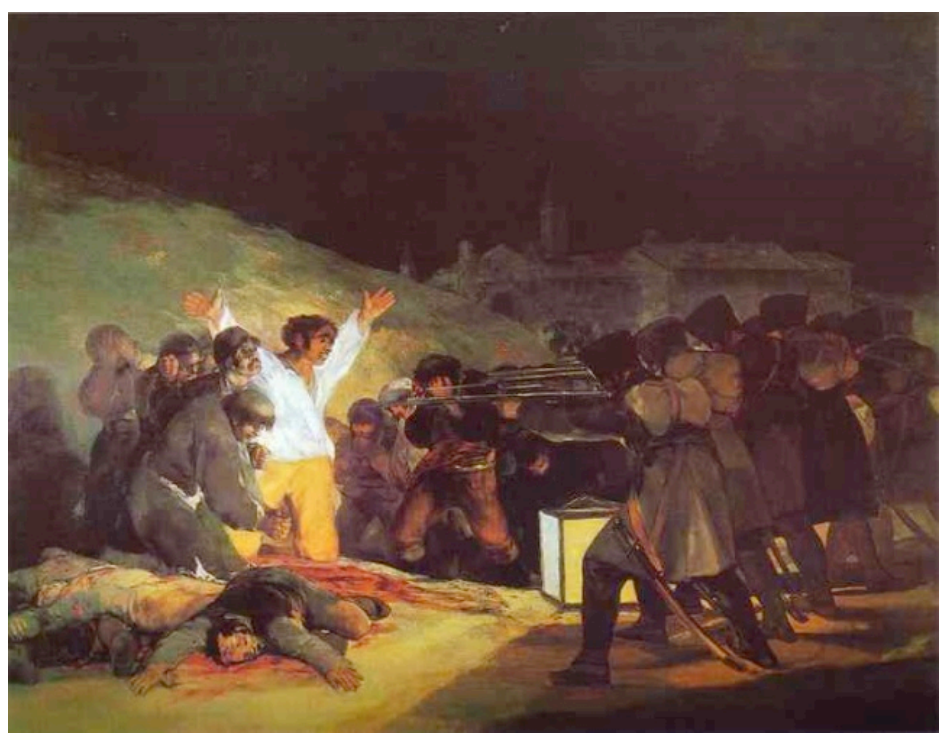

Fuzilamentos de 3 de maio de 1808

(Francisco de Goya, 1914, óleo sobre tela, 268 × $347 \mathrm{~cm}$ )

A cena é, ao mesmo tempo, de intensidade e de extensidade, visto que contempla um conjunto de atores impactados pelo fuzilamento; há uma narrativa configurada por tempo, espaço e atores, vários mortos empilhados e outros já em mira de execução. A extensidade se dá pela conjugação de passado (mortes que antecedem o presente), de presente (a carabina em mão) e o futuro (a morte do homem de branco no centro do quadro).

Na Série das ligas, não há uma narratividade extensa e tão presente quanto nas pinturas de batalhas e de guerras. Em Duke Lee, é mais evidente a ordenação dinâmica que configura os padrões de ritmo. É, portanto, por meio do jogo tensivo entre movimento e repouso, tonicidade e atonicidade das formas de expressão das linhas que percebemos, ora mais ora menos intensamente, os objetos pictóricos da Série das ligas. As lâminas pictóricas levam-nos mais para a esfera sensível, ou mais para o inteligível, dependendo das estratégias utilizadas pelo enunciador. 
OPERAÇÕES FORMAIS NA SEMIÓTICA DAS LIGAS 


\subsection{Relação de contraste e valores}

As reflexões que seguem partem do princípio básico de que o sentido se dá por meio da operação entre a forma da expressão e do conteúdo e a substância da expressão e do conteúdo. Essa é a condição de qualquer signo como operação entre formas. $E$ a essas formas subjazem suas respectivas substâncias.

Já foi dito que os artistas, ao escolherem materiais e optarem por aplicá-los segundo diferentes técnicas, determinam seu fazer plástico pela coerção que essas escolhas implicam. À instância da enunciação, a substância da expressão parece evidenciar-se mais ou menos, de acordo com essas técnicas.

Assim, podemos dizer que, além das coerções dos gêneros e das "escolas pictóricas", é a operação da substância da expressão em forma de expressão e do conteúdo que contribui para o sentido de uma obra de arte. Ou seja, há na enunciação desses objetos um acordo implícito entre os sujeitos da enunciação, enunciador e enunciatário. Utilizamos "substância da expressão" apenas de maneira didática, já que entendemos o mundo enquanto linguagem, sendo ela presentificada pela relação de sua forma e de sua substância tanto da expressão quanto do conteúdo, como afirma Hjelmslev.

Por mais paradoxal que possa ser, o signo é, portanto, ao mesmo tempo, signo de uma substância de conteúdo e de uma substância da expressão. [...] Contudo, parece mais adequado utilizar a palavra signo para designar a unidade constituída pela forma do conteúdo e pela forma da expressão e estabelecida pela solidariedade que denominamos de função semiótica (HJELMSLEV, 2009, p. 62).

Já na "paleta" de um pintor se apresentam os primeiros recortes das substâncias da expressão (a substância já em formatação). Seus efeitos de sentido, por exemplo, podem variar entre um efeito de sentido de desenho, um efeito de sentido de pintura, entre outros efeitos, de acordo com as qualidades plásticas dessa ou daquela substância escolhida. Nesse aspecto, haveria então uma reflexão sobre o fazer, uma metalinguagem plástica. O artista fala do desenho através do desenho, fala da cor através da cor.

Estipulamos a seguir os tipos de relações existentes em uma pintura, analisando elementos da mesma categoria, que chamaremos de "contraste". Nos objetos, o contraste ocorre quando selecionamos para a análise elementos de 
mesma categoria plástica para servir de comparação; nesse caso, o contraste se dá pela forma da expressão. Assim, teríamos o contraste entre cores, o contraste entre as linhas, o contraste entre cores e linhas:

1. relação de mesma hierarquia: relação entre cores; relação entre linhas;

2. relação de hierarquias diferentes: relação entre linhas e cores. Por exemplo, a linha limitando a cor.

Há também um terceiro tipo de relação que seria a relação sintáxica ou de contraste, que seria o contraste sintáxico:

3. relação sintáxica ou de contraste: no caso da Série das ligas, como veremos, a relação é de preenchimento e/ou de esvaziamento.

Primeiramente, observemos o uso da substância da expressão cor. Por uma razão analítica, atentaremos ao plano da expressão separadamente. A saber:

\section{EXPRESSÃO - TORMA: maneira de articular a substância traços diferenciais sensíveis}

Selecionamos alguns movimentos de vanguarda artística para demonstrar como se dão as operações de relação entre a substância da expressão e a forma da expressão:

A) Impressionismo/Pós-impressionismo (divisionismo, pontilhismo): dá-se pela busca da exclusão da linha (triagem) - relação entre cores.

B) Abstração geométrica: linha e cor, em relação de cooperação, como adjuvantes um do outro para a delimitação geométrica da cor (mistura) relação entre cor e linha, vice-versa, evidenciando ou a linha ou a cor.

C) Expressionismo abstrato: mistura de linha e cor; linha e cor mesclam-se no enunciado pictórico. A cor torna-se linha, a linha faz-se pela cor, não em detrimento dela. Operação de mistura em grau avançado.

No impressionismo, por exemplo, ainda existe um crivo de leitura que é de "natureza semântica", já que "solicita o significante planar e, assumindo feixes de 
traços visuais, de densidade variável, aos quais constitui em formantes figurativos, dota-os de significados, transformando assim as figuras visuais em signos-objetos" (GREIMAS In: OLIVEIRA, 2004, p. 80). Dessa maneira, evidenciam-se as operações de exclusão da linha e inclusão dos procedimentos de cores. Os impressionistas experimentam a inclusão da cor e o apagamento da linha; ainda assim, seus enunciados possuem um contrato com a representação do mundo natural.

Tomando as cores como actantes de um percurso narrativo da expressão, é na relação entre as formas da expressão que as cores engendram o conteúdo "barquinho, rio etc". Supondo que as interações entre as substâncias cor e linha, nos exemplos a seguir, sejam, de fato, a base para gerar significado num texto pictórico, é na semiose entre os eixos articulatórios que "recortamos" o objeto em unidades semânticas "discretas, legíveis". Ou seja, ainda que a pintura seja da ordem do abstracionismo, as unidades mínimas discretas são reconhecíveis por meio de recorte de "linha" e de "cor" como figuras semânticas, como "quadrado", "círculo", "ligas" etc.

\section{A) Impressionismo/Pós-impressionismo (divisionismo, pontilhismo)}

Figura 4.1

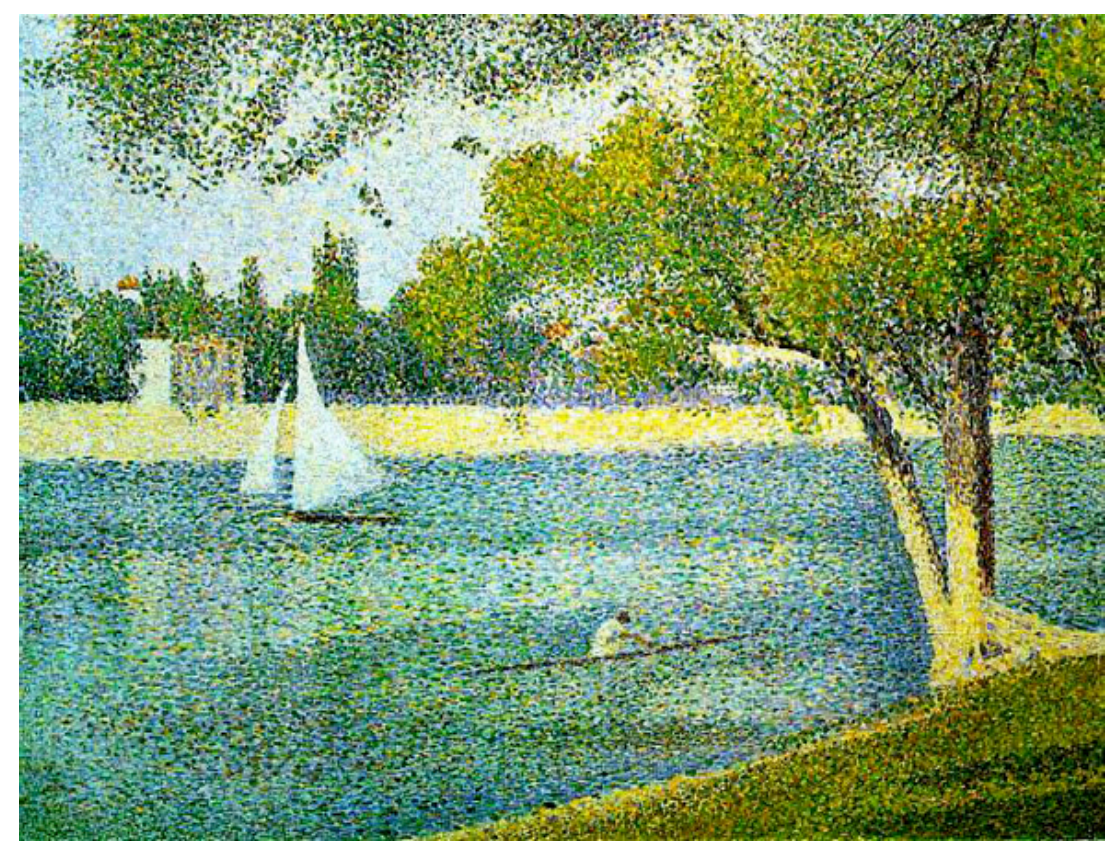

O Sena e a Grande Jatte na primavera

(Georges Seurat, 1887, óleo s/tela, 65 x $82 \mathrm{~cm}$ )

Em boa parte da pintura impressionista/pós-impressionista, evidencia-se a escolha do enunciador por apagar os limites tradicionais do contorno das figuras, por superar o conflito entre linha e cor, enaltecendo apenas a cor. Os impressionistas 
começaram a rejeitar a linha, ou seja, a limitação pelo contorno; da igual forma, o mesmo ocorreu com o pós-impressionista Seurat.

Supomos que suas obras articulam as substâncias COR para criar um efeito de sentido COR em devir (cor em formação - substância desejosa de forma). A identidade da cor só pode ser validada pela relação de proximidade com outras cores justapostas. Ironicamente, surgirão no enunciado da tela novas cores, ausentes, muitas vezes, da paleta do pintor.

Há um debate que coloca em xeque a cientificidade pretendida pela arte impressionista. De certa forma é ingênuo pensar em uma arte que se pretende científica: os pintores tinham em vista representar o fenômeno físico da "luz" sobre a cor na tela. No entanto, a frustração do "cientista-pintor" é que, independentemente do esforço em vão do pintor, o sujeito da enunciação acaba por recortar, apreender o conteúdo "barquinho", "rio", "árvore" etc.

Caso não haja figuras semânticas reconhecíveis do mundo natural (caso das pinturas abstratas que veremos a seguir), o sujeito da enunciação, inserido em um cânone, já recorta o sentido do lugar em que se encontra, o que ajuda a dar direção ao seu enunciado pictórico. É somente a partir desta primeira visada em relação aos elementos expressivos que a arte, em seu continuum, derivou do impressionismo para a abstração.

O tratamento da cor foi sendo aprimorado e cada vez mais os enunciados plásticos suprimiram as figuras discursivas e apoiaram-se apenas nos elementos plásticos, reduzindo essas figuras, em figuras como quadrado, retângulos, círculos, retas e "cores puras". 


\section{B) Abstração ${ }^{4}$}

Figura 4.2

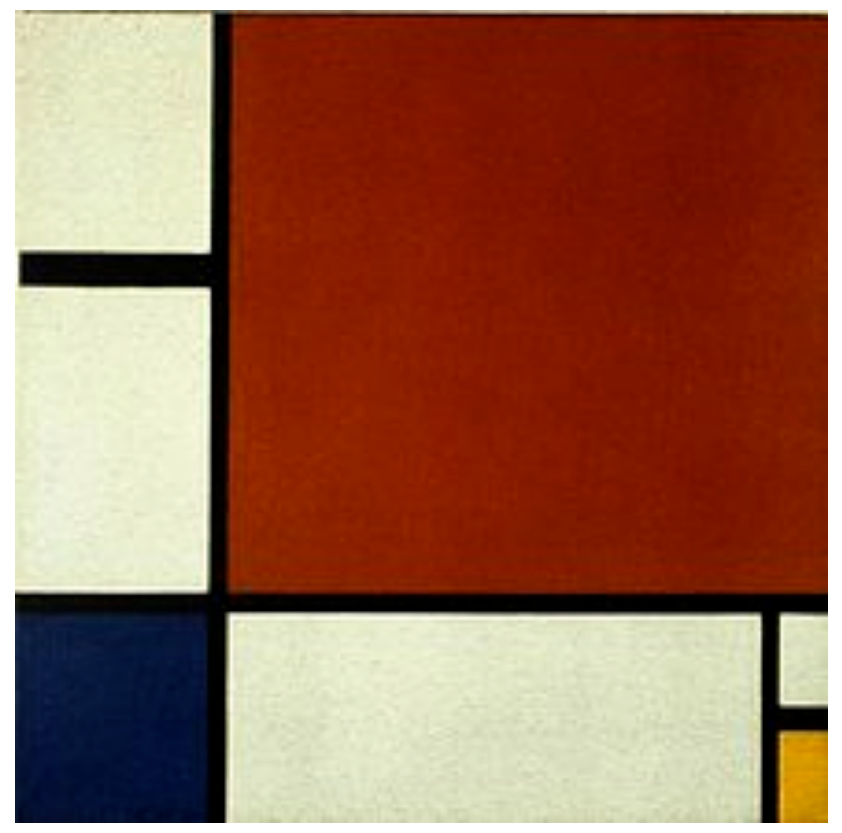

Composição Il em vermelho, azul e amarelo

(Pieter Cornelis Mondrian, 1930, óleo s/tela, 86 x 66 cm)

Nesta composição geométrica, o enunciador estende faixas de cores contrastadas entre si com margens nítidas e zonas de cores amplas. Aqui, a geometria faz o papel das linhas que contornam a cor. O caráter de contorno atribuído à forma geométrica "desenha" a cor, recorta-a.

Nessas pinturas, colocam-se lado a lado, em oposição, as cores, a fim de atribuir à cor um caráter distintivo. A cor desenvolve um programa narrativo quando é organizada, e a figura discursiva, quadrado, retângulo, que dela se desenvolve, possui novamente elementos que o impressionismo buscou eliminar: a estrutura, a proporção. Nesse sentido, há desenho e pintura: relação entre linha e cor. O projeto construtivo abstrato não exclui a linha; ao contrário, é a linha que dá limite à cor, e é a cor que dá limite à linha, em uma operação de englobante/englobado. A identidade da cor parece intransponível na abstração geométrica: um vermelho é um vermelho, um azul é um azul, um amarelo é um amarelo.

Como afirmamos, o enunciatário consegue recortar as figuras do enunciado porque há, além das operações entre linha e cor, um título ou o próprio nome do

\footnotetext{
${ }^{4}$ Embora se reconheça que uma figura geométrica é concreta, sua utilização em lugar de figuras simulativas do mundo natural é normalmente conhecida como arte abstrata.
} 
artista pressuposto é também conhecido por estar inserido em determinado cânone: o do artista abstrato.

\section{C) Expressionismo abstrato}

Figura 4.3

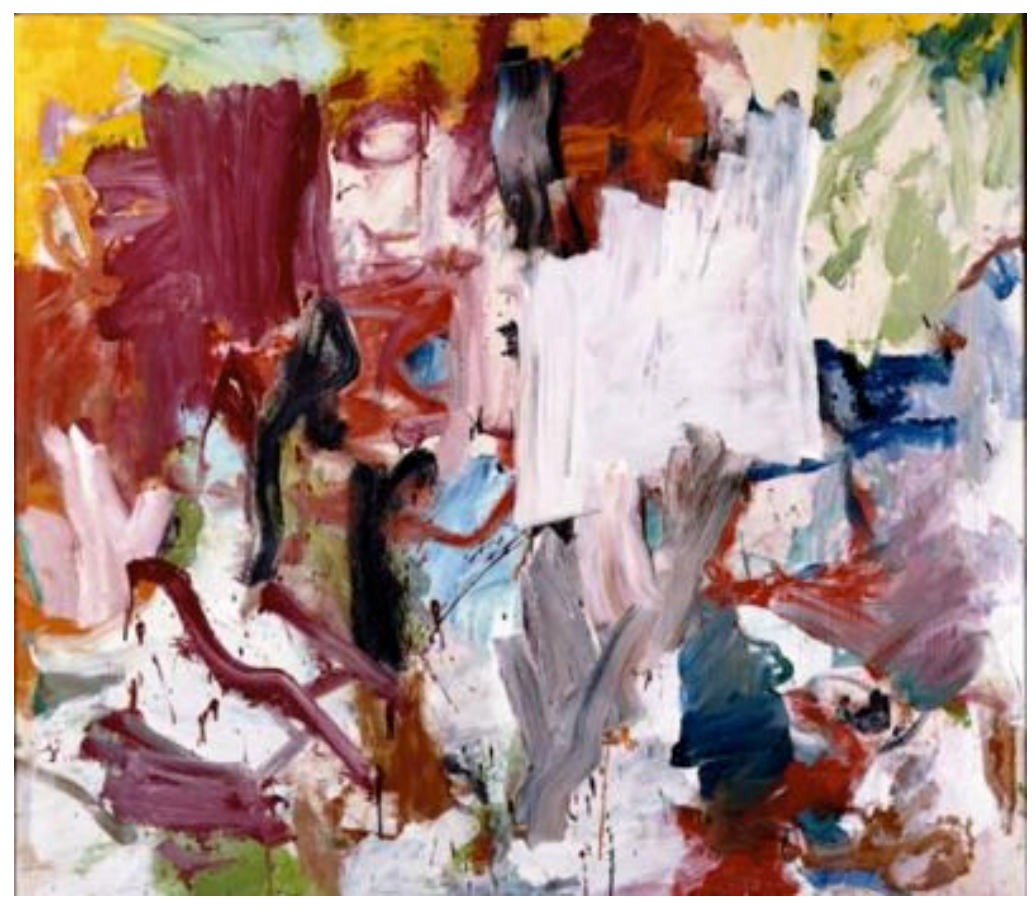

Sem título XXV

(Willem de Kooning, 1877, óleo s/tela, $185 \times 223 \mathrm{~cm}$ )

O esforço em diminuir o contraste entre cor e linha é a base do projeto pictórico do expressionismo abstrato. Linha e cor misturam-se. Não vemos limites precisos entre elas. Exemplo disso são as pinturas do artista plástico De Kooning, como na figura 4.3.

Se por um lado, os impressionistas buscaram reduzir o contraste entre linha e cor, excluindo o programa narrativo da linha (desenho), por outro lado, a ação pictórica dos expressionistas abstratos dedica-se a juntar dois efeitos de sentido caros à pintura: figura e fundo, fundindo assim linha e cor, não excluindo nem um nem outro. No quadro abstrato geométrico, como vimos, ainda existe um limite da cor provocado pela linha, mesmo que apenas percebida no limite das cores. No expressionismo abstrato não há contraste de valores evidentes entre linha e cor. Nessas pinturas, o limite da cor não existe. A cor quer escapar da ruptura que a borda do quadro, o enquadramento, impõe aos impressionistas e quer escapar também da linha do abstracionismo geométrico que moldava a cor, limitando-a em 
um esquadro. No expressionismo, pelo contrário, a cor quer ser infinita, emissiva, e, por isso, deparamos com o efeito de sentido de indefinição (ZILBERBERG, 2006, p. 139).

As variações aparentemente aleatórias de linha-cor formam planos superpostos, dificilmente distinguíveis, ao longo desse "caminho" que a arte da pintura tomou. Isso nos possibilita pensar a tensividade na pintura. Substituímos, por ora, uma abordagem subordinada às questões apenas da ordem conteudística para estudar as questões impostas pelos contrastes cromáticos e a tensão entre linha e cor. Tais relações são regidas pelo ritmo, como veremos a seguir, na semiótica da Série das ligas de Duke Lee.

\subsection{Relação sintáxica da Série das ligas}

As operações entre forma e substância da expressão possibilitam a obtenção de sentido erótico figurativo/erótico plástico proposto pelo título da série, já que é na relação entre as formas que se dá o entendimento "ligas". No plano do conteúdo, temos os universos figurativos (ligas, corpo feminino, erotismo) e no plano da expressão a operação de uso da linha, da tinta, do grafite etc.

Uma das experiências que mais afeta diretamente o sentido é a percepção espacial. Por exemplo, ao observarmos os elementos expressivos de uma obra, percebemos que os espaços são compreendidos nas delimitações expressas ou sugeridas. Há duas maneiras de observar os espaços: uma internamente e outra exteriormente. Externamente, podemos observar os espaços físicos e perceptivos, simulados na enunciação pelas figuras discursivas que traduzem as distâncias do olhar do enunciador/artista em longe e perto, do objeto a ser pintado. Internamente, serão analisados os espaços perceptíveis nas relações entre os elementos da ordem plástica, que são baseados nas orientações dos traços e volumes.

As pranchas da Série das ligas, de Wesley Duke Lee, estão dispostas de maneira sintáxica, em que a relação entre forma e substância da expressão (tinta, cor, grafite, linha) estão arranjadas de maneira a preencher ou a esvaziar os efeitos de sentido de corpo feminino vestido parcialmente com roupas íntimas (as ligas). Como se pode observar, a primeira delas (tela 1), está no nível mais alto de esvaziamento e a última (tela 10) está no nível mais alto de preenchimento. Observemo-las na sequência proposta. Para melhor visualização, cada lâmina encontra-se ampliada separadamente no anexo (p. 141-151): 

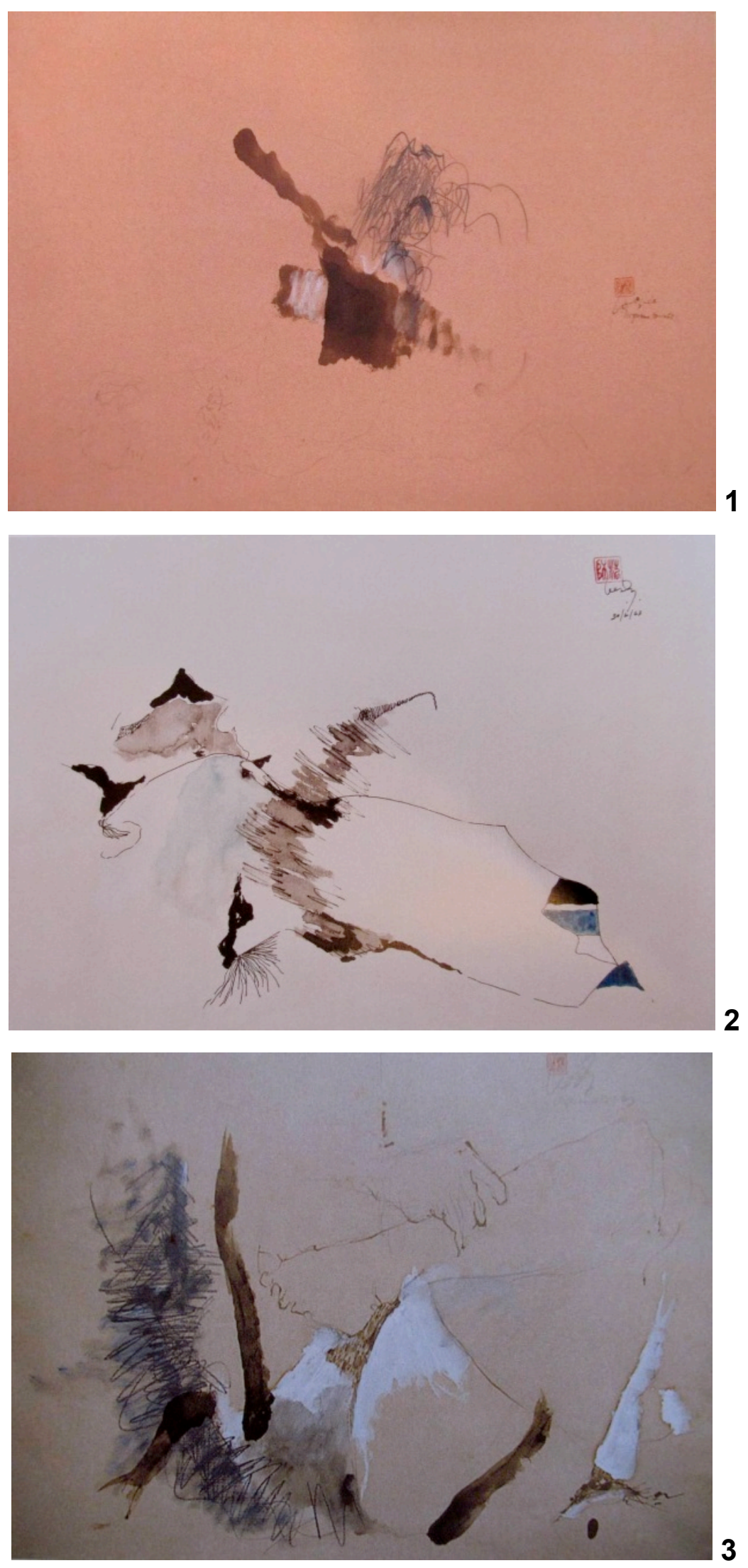

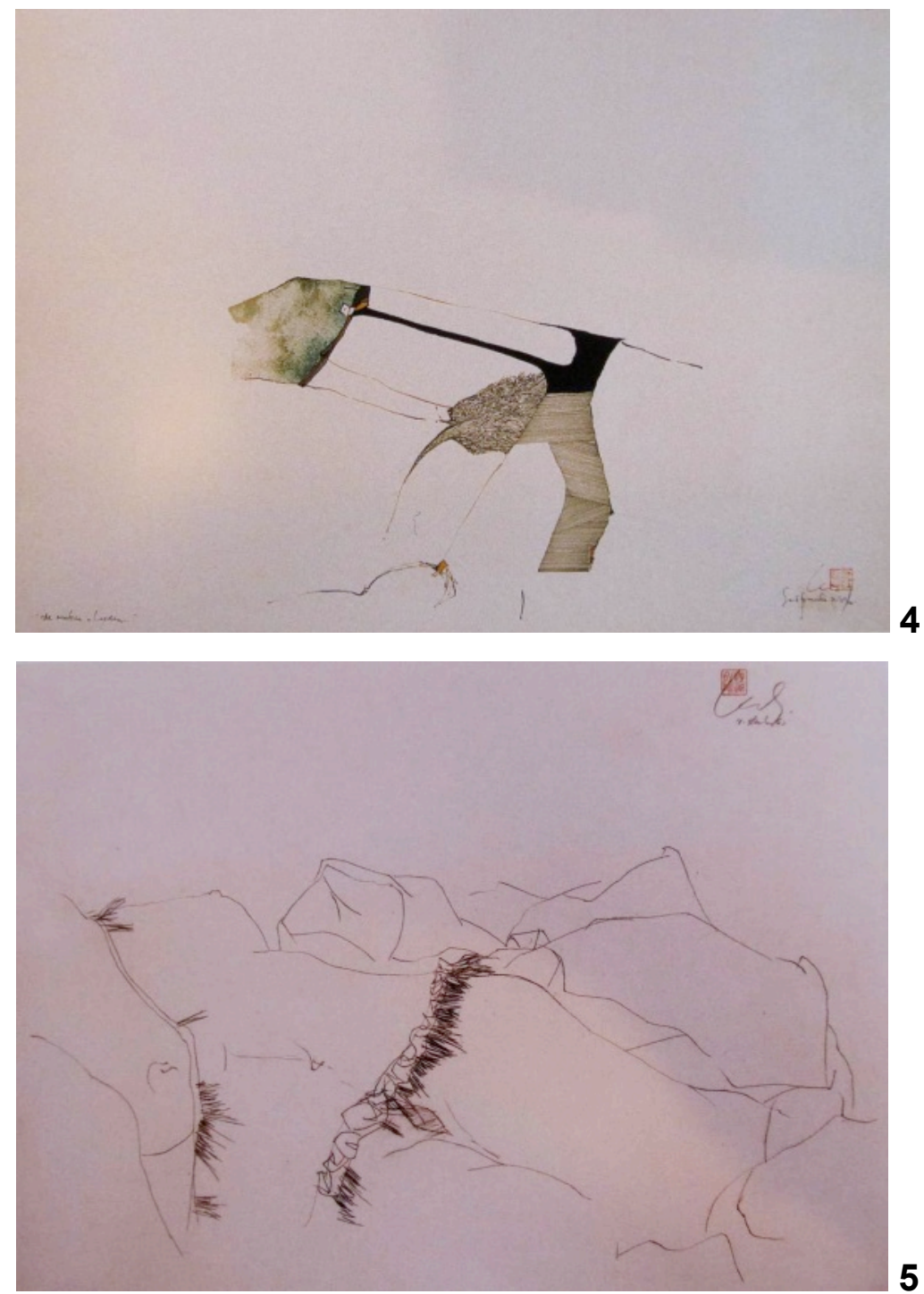

5

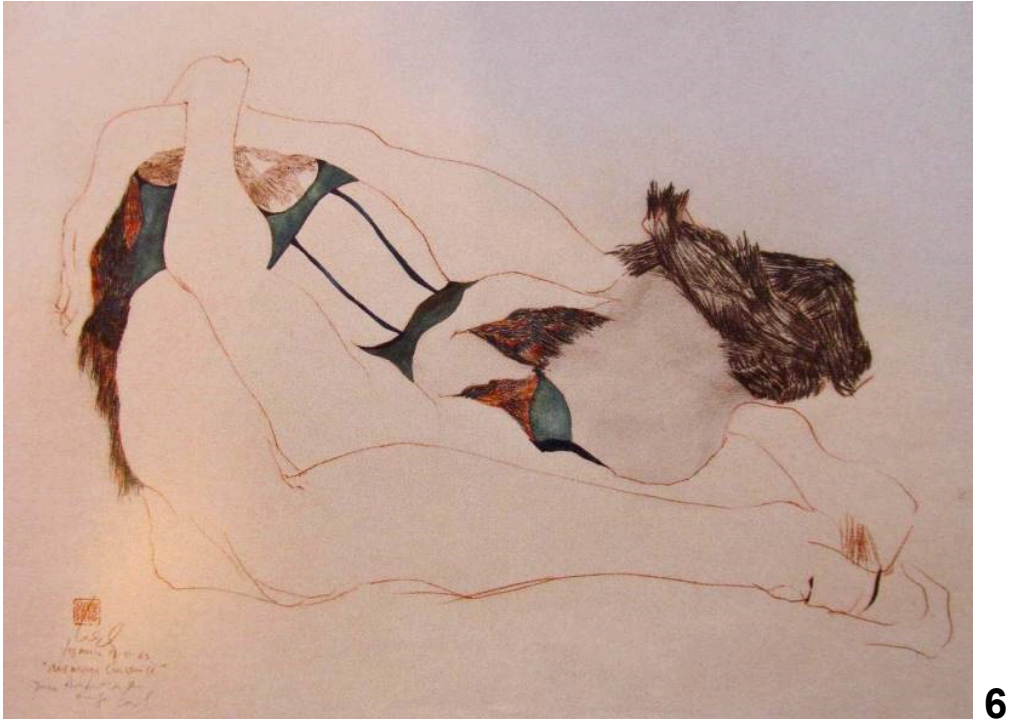



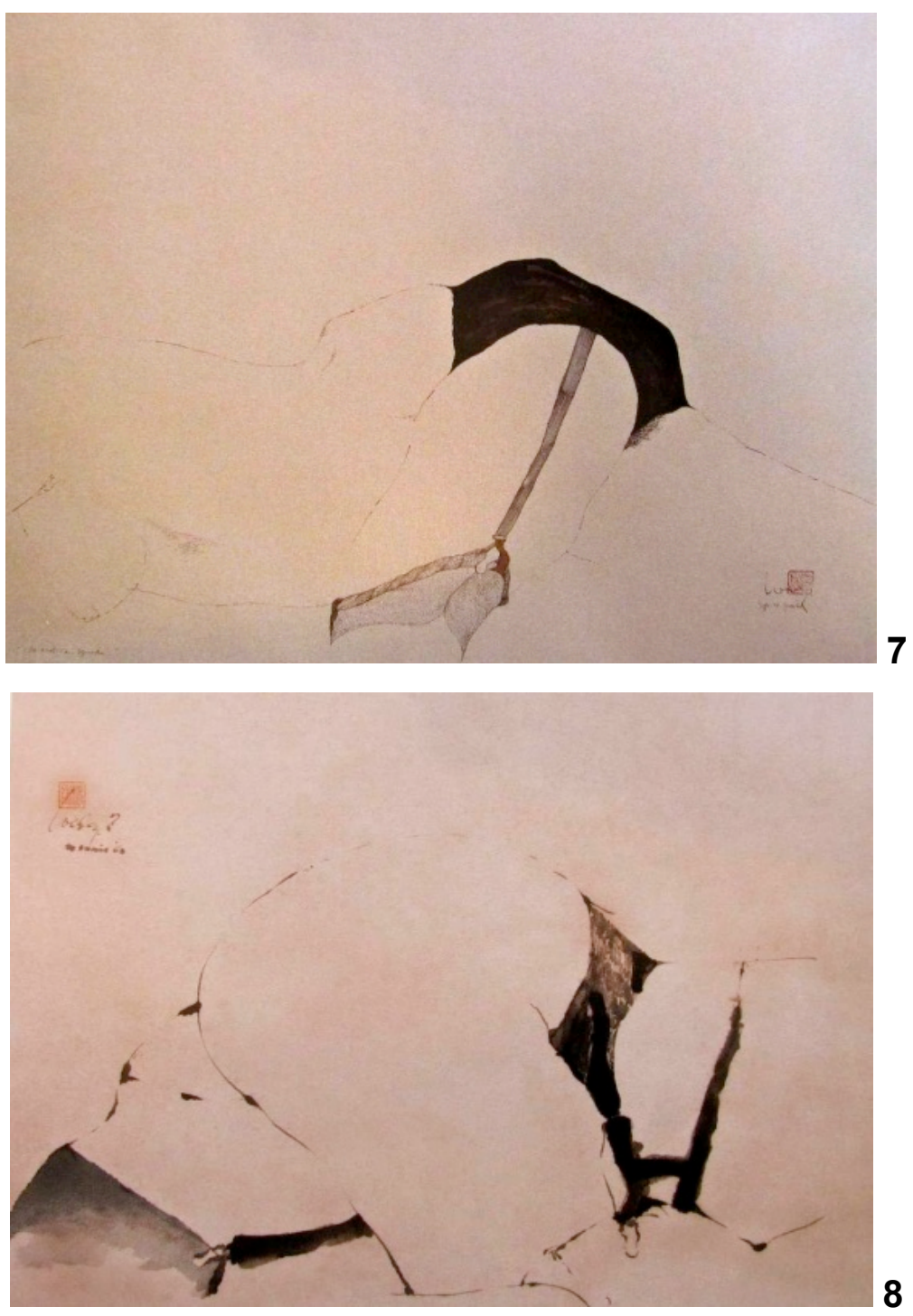

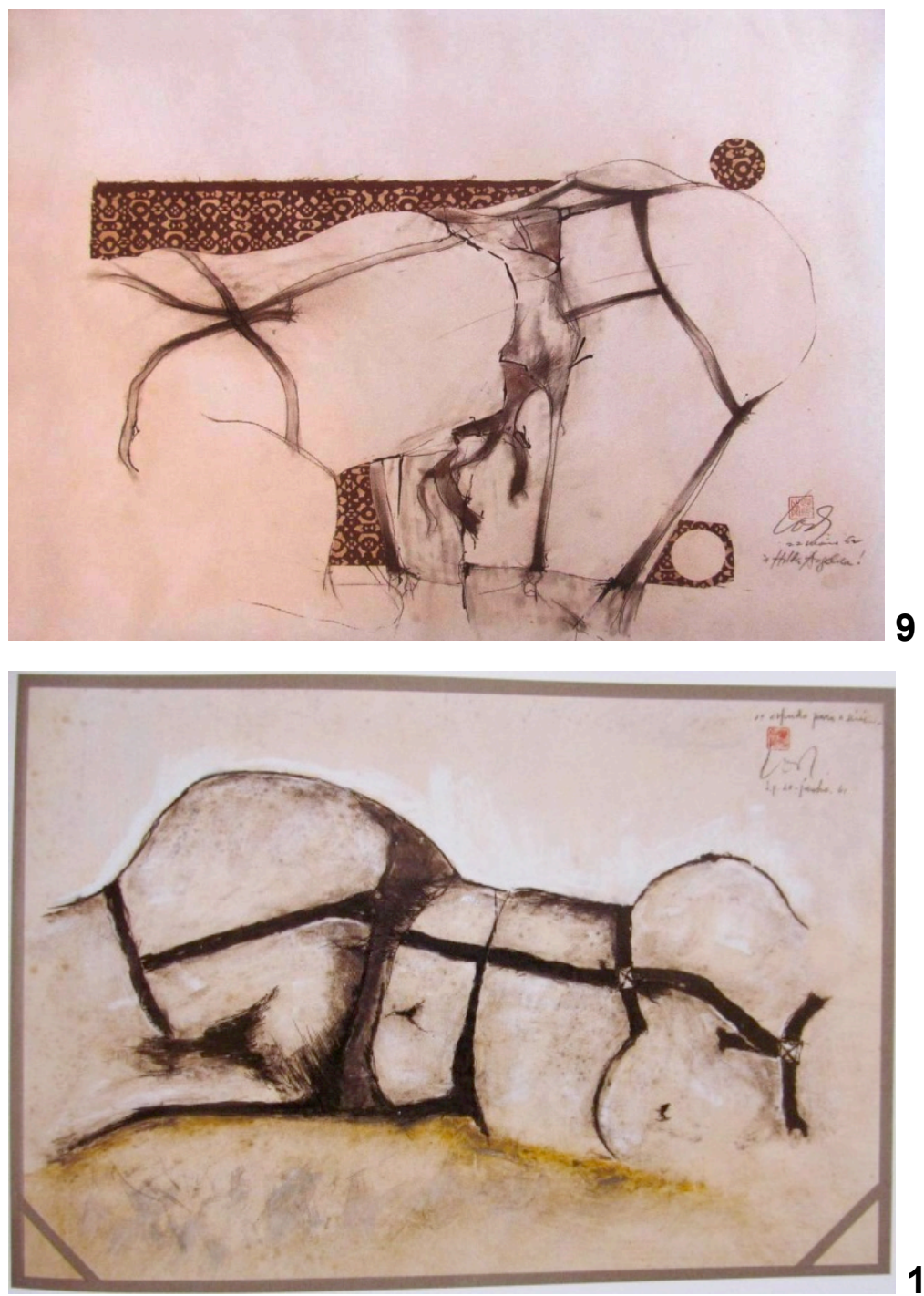

\section{Tela 1:}

Série das ligas, (Legano, Itália) 1962

Betume e grafite s/papel colorido, $48 \times 67 \mathrm{~cm}$

Tela 2:

Série das ligas, 1963

Nanquim e aquarela s/papel, $32 \times 43 \mathrm{~cm}$

Tela 3

Mulher, 1963

Betume e óleo s/papel, 50 x $67 \mathrm{~cm}$

\section{Tela 4}

Ode erótica a Lydia, 1960

Nanquim e ecoline s/papel,48 x $63 \mathrm{~cm}$

\section{Tela 5}

Série das ligas, 1962

Crayon s/papel, 45 x $59 \mathrm{~cm}$
Tela 6

Anêmona circense (Legano, Itália), 1963

Nanquim, aquarela e sépia s/papel, 49 × $67,5 \mathrm{~cm}$

\section{Tela 7}

Ode erótica segunda..., 1961

Nanquim e ecoline s/papel, 48 x $63 \mathrm{~cm}$

Tela 8

Série das ligas, 1960

Betume, aquarela s/papel, $45 \times 60 \mathrm{~cm}$

\section{Tela 9}

Hilda Angélica, 1962

Carvão, nanquim, guache e colagem s/papel, $47,5 \mathrm{x}$ $62 \mathrm{~cm}$

\section{Tela 10}

Primeiro estudo para a série..., 1961

Nanquim e guache s/papel, $41 \times 61 \mathrm{~cm}$ 
Inicialmente, tomemos como ponto de partida elementos do universo exterior à obra, que implica, portanto, uma leitura externa, mas presente de maneira implícita. Sendo assim, vemos a espacialidade manifestada na relação entre o enunciador artista e seu objeto (a mulher que posa para ele). A ausência de temática figurativa na Série das ligas poderia ser entendida tanto por ser uma escolha formal ou, até mesmo, a negação de relações afetivas com o tema.

Sabemos que Duke Lee inicia sua Série com a sua "Ode erótica a Lydia" de 1960. Ele, diante de sua amada, inicia uma série que o faz pensar no universo feminino, sempre conturbado à sua volta. Ele afirma em um trecho transcrito de seu diário que a Série das ligas

[...] lidava instintivamente com um assunto muito complicado (e que para os homens é um terror): o princípio feminino [...] Estava me aproximando do vaso, o vaso máximo que é o útero, onde se põe tudo. Comecei pelo púbis tentando vencer o medo; dele fui avançando até conseguir fazer uma figura inteira, o que levou 10 anos. A imagem aparecia sempre por partes, faltando pedaços [...] Fui me aproximando do problema lentamente, timidamente (DUKE LEE In: COSTA, 2005, p. 56).

Ao longo da Série (na ordem decrescente, da tela 10 à tela 1), o enunciador parece despir a mulher que está diante dele.

Ao despi-la, o enunciador aproxima-se do objeto e cada tela que segue é um fragmento daquilo que o olho do artista está focando, de modo que, na tela 10, a mulher está a uma distância maior em relação à tela 1, que está tão próximo do olho do artista que o enunciatário vê pintado na tela: apenas o ventre e os pelos pubianos.

A Série das ligas orienta-se por uma oposição fundamental entre exterioridade (roupas íntimas) e interioridade (corpo). O enunciador vai paulatinamente despindo seu objeto para penetrar-lhe a intimidade, um desejo erótico não só de entrar em conjunção com seu objeto, mas também de descobrir o que se passa no seu interior.

Homologando, temos a exterioridade com o erotismo figurativo e a interioridade com o erotismo plástico. Enquanto o artista despe a modelo, ao mesmo tempo penetra na interioridade do objeto estético, revelando os mecanismos e segredos do plano da expressão, que vêm à tona.

Em um extremo, vemos claramente uma mulher idealizada (tela 10, um erotismo figurativo); em outro extremo, o universo enigmático da feminilidade e seus 
mistérios (tela 1, um erotismo plástico). O fundo avermelhado do papel figurativizaria talvez o rosado da pele feminina na região íntima.

Além dos volumes e dos traços representativos, há também o caráter dinâmico dado pelos movimentos visuais homologados pelas diagonais e outros elementos expressivos, como podemos notar na imagem da tela 1 :

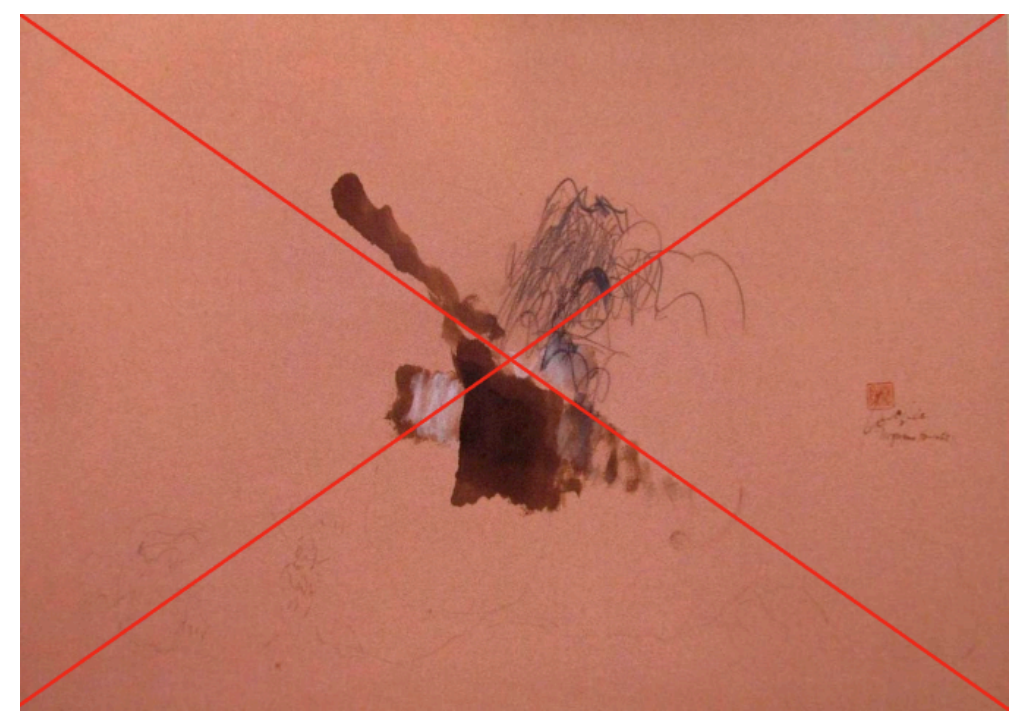

Uma primeira leitura, ocupada de valores internos, nos leva a perceber que se trata de uma superfície retangular, composta de elementos visuais, constituidores de uma tela da Série das ligas. Em sua composição concêntrica, vemos um módulo de cor feito com betume mais intenso no miolo, que escorre diagonalmente para cima, à esquerda. Vemos também riscos mais finos em tons acinzentados ao lado direito desse módulo de tinta, indicando uma repetição rítmica desses elementos.

O módulo isolado de cor feito pelo betume está em contraste com o branco, localizado ao seu lado. O branco delimita o módulo de betume e, por uma relação de contraste tonal (luz e sombra), evidencia ainda mais seus limites. Vale lembrar que, mesmo que todos os elementos da ordem do visual (forma e substância da expressão) estejam arranjados sobre o papel colorido, não ocupam exatamente o centro geométrico do retângulo, mas escapam em todas as direções. Esse arranjo é uma operação enunciativa: o enunciador, aproximando-se, conduz o olhar do enunciatário, deslocando os olhos do enunciatário para um lugar menos confortável, pois que o centro geométrico seria o lugar mais confortável à visão.

Entende-se que o centro geométrico é a marcação central do quadro. Esse centro fundamenta-se na construção do enunciador da chamada perspectiva 
clássica, empregada na pintura para simular efeitos perceptivos do mundo natural, através da ordenação de elementos próprios da linguagem pictórica. Ao longo da história da pintura, esse recurso foi exaustivamente utilizado, a fim de criar efeito de harmonia e equilíbrio.

Dessa maneira, se forma e substância da expressão, empregadas no suporte, não estão centradas no ponto de fuga, elas não contribuem para o arranjamento da expressão "perspectiva"; no entanto, existe uma preocupação em ocupar esse espaço central. O deslocamento do objeto percebido permite a apreensão total do objeto pelo enunciatário. Ou seja, é a organização do plano da expressão (os contrastes entre a borda do papel e o centro topológico do retângulo) que ajuda a dar o efeito de sentido de deslocamento.

Embora o enunciador não se utilize da perspectiva clássica, ele parece ter-se ocupado em determinar o centro do retângulo como eixo condutor do olhar do enunciatário. Assim, o enunciador conduz o enunciatário a identificar a região pubiana e o quadril da figura feminina, além das ligas, no centro desse retângulo. Trata-se de eixos de orientação topológica que indicam um posicionamento perceptivo da tela.

Revela-se então uma instância de enunciação modalizada pelo saber fazer que manifesta meticulosa precisão na elaboração dos signos visuais. Esse manejo do olhar é uma operação estética de concentração sensível, que faz o enunciatário buscar, entre os volumes e os traços, algo que não apenas remeta à figura feminina, mas também e, sobretudo, às ligas que estão em ausência no corpo feminino, como um paradigma in absentia. A cena apresenta a participação do enunciador no evento que pinta. Fazendo uma analogia entre pintura e literatura, temos aqui um enunciado em primeira pessoa.

Outro aspecto composicional que conduz o olhar do enunciatário é a linha mais grossa em diagonal que caminha para a extremidade e nos permite identificar mais um contraste (dinâmico/estático). Neste caso, o olhar é conduzido para fora do centro geométrico do retângulo. A relação de contraste de orientação, ora centralizando, ora descentralizando o olhar, dinamiza o movimento na obra de arte.

O fato de o branco estar ao lado do betume também cria outro contraste; nesse caso, contraste tonal mais intenso e acentuado. Contraste tonal é o contraste dado pela diferença entre um tom mais escuro e outro mais claro, não necessariamente da mesma cor. Por exemplo, na escala de cinzas, podemos encontrar infinitas 
gradações de tonalidade que, acrescentadas às cores, dão mais efeito de luminosidade ou de escurecimento a depender da intensidade. A seguir, o esquema de contraste tonal mais acentuado e de contraste tonal menos acentuado:

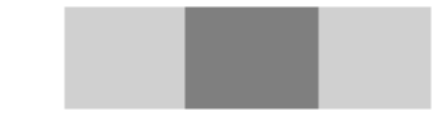

contraste mais acentuado (mais intenso)

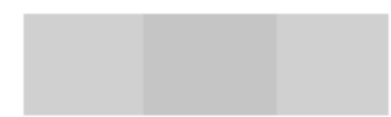

contraste menos acentuado (menos intenso)

O papel em cores, nesse caso (tela 1), é uma superfície monocromática neutra. Nela, adicionou-se o betume, que possui um "tom" próximo ao tom do papel. Esse contraste tonal seria menos acentuado. O módulo de tinta vai ganhando intensidade na região isolada central, pois ali as cores estão em relação de oposição. E o branco produziria a oposição que mais salta aos olhos. Aqui, temos um contraste tonal mais acentuado.

O que estamos verificando é que o contraste nas artes plásticas funciona como funciona a diferença no signo linguístico. No signo linguístico, um sentido se faz pela diferença que estabelece com outro signo linguístico. Nas artes plásticas, um branco ganha sentido quando se opõe ao preto, por exemplo. A junção de uma cor com outra forma um sintagma plástico; as gradações de tonalidade permitem as variações de intensidade. Se no sintagma verbal, adjetivos e advérbios introduzem intensidade no enunciado, nas artes plásticas é a gradação do contraste que indica intensidade.

Além do aspecto contrastivo dos signos, retomemos o princípio de arbitrariedade do signo, de Saussure. O que notamos na Série das ligas é uma relação de arbitrariedade do signo plástico ao representar "ligas". Já que os traços e rabiscos, caso não fizessem parte de uma série, nos remeteriam a quaisquer outras formas ou figuras, não necessariamente "ligas" ou outra figura que faça parte do universo semântico do erotismo feminino. No exemplo da tela 1, há uma saturação plástica e, consequentemente, uma extinção figurativa: vemos rabiscos ritmados.

Culturalmente, por sabermos que a imagem pertence a uma tela da Série das ligas, somos tomados por um ímpeto cultural de associar os rabiscos a pelos pubianos, pois 
todo meio de expressão aceito numa sociedade repousa em princípio num hábito coletivo ou, o que vem a dar na mesma, na convenção. Os signos de cortesia, por exemplo, dotados frequentemente de certa expressividade natural (lembremos os chineses, que saúdam seu imperador prosternando-se nove vezes até o chão) não estão menos fixados por uma regra; é essa regra que obriga a empregálos, não seu valor intrínseco (SAUSSURE, 1996, p. 82).

O que queremos dizer é que, nas lâminas que vão do esvaziamento ao preenchimento, observamos o uso de elementos expressivos plásticos que se referem às metonímias do corpo feminino e à sua vestimenta íntima. Assim é que podemos associar os rabiscos e os volumes de tinta, pela relação estrutural da série, com figuras eróticas.

Gradativamente, o enunciador abandona ou retoma o uso de figuras mais próximas do universo do mundo natural. Na régua vetorial que apresentamos estão dispostas dez telas, numeradas de 1 a 10; notamos aí que aquelas que estão mais figurativizadas possuem mais densidade semântica e aquelas que estão na outra extremidade possuem mais densidade plástica e caminham para a abstração.

No recrudescimento da figurativização, temos uma aproximação mimética do objeto; mesmo no caso em que parte do corpo e as ligas são vistos parcialmente, não se pode falar em saturação figurativa, pois que a cor da pele se confunde com o fundo; não há propriamente preocupação em apresentar todos os elementos da cena. Nas demais telas, observamos um encaminhamento para a minimização da figurativização, prevalecendo elementos plásticos. Neste último caso, o texto perde em transparência, mas ganha em poeticidade.

No caso das telas com maior densidade semântica, ou que figurativizam o objeto com maior quantidade de traços semânticos teríamos um enunciador retratista; o enunciador das telas mais plásticas, no entanto, escolheu elementos de ordem abstrata, visto trabalhar com a plasticidade, inaugurando formas para as mesmas substâncias. O semântico estaria próximo da simulação do mundo natural, assim como o plástico estaria mais distante dessa simulação. Vários Duke Lees dentro de um.

O enunciador modula ainda outros elementos plásticos para dar movimento e dinâmica à sua composição. Assim, quando as hachuras em tons cinza-azulados desviam o olhar do centro em direção à borda, o enunciatário tangencia o ponto de fuga, o que dá movimento e dinâmica ao enunciado. O movimento também é dado 
pela diagonal de betume (linha grossa), que escapa, do centro à esquerda, e vai para fora do foco central da composição.

Podemos concluir que, apesar da concentração de elementos plásticos num ponto muito próximo ao centro da tela, o que, isoladamente, faz com que um enunciatário desatento os entenda como estáticos, eles são dinâmicos pelas relações que estabelecem entre os elementos do quadro: parecem solicitar a emissividade da continuação através de suas potencialidades.

A mancha de betume quer expandir a área de concentração da tinta, que escorre pela diagonal superior esquerda; as linhas, que no seu devir possuem dimensão única, parecem ganhar volume e aspecto de mancha; aplicadas repetidas vezes, as linhas, umas ao lado das outras, expandem-se também para garantir sua liberdade fluida, o que, a nosso ver, engendra o efeito de sentido de dinamismo das Ligas, garantindo um ritmo veloz, que produz o efeito de sentido de rápido desnudamento. E é esse ritmo elemento de pertinência para a análise da série como um todo.

As oscilações rítmicas tanto pelas rupturas e superposições de linhas e cores, como também pelo jogo figurativo que mostra ou esconde as ligas garantem maior ou menor intensidade nas relações da ordem do estético. Dessa forma, a imagem que precede aquela que está preenchida é necessariamente aquela que está esvaziada de ligas, um sempre dirigindo ao outro. Os contrastes criam tensões espaciais, e as semelhanças dos elementos visuais, que compõem a obra, criam tensões rítmicas. No entanto, essas duas relações (espaço e ritmo) são interdependentes, pois são aspectos fundamentais do movimento.

Historicamente, os pintores utilizavam jogos expressivos para que seus enunciatários aderissem a sua lógica, um certo poder de conduzir o olhar em trajetórias previamente calculadas, para que não ficassem à deriva, dando ritmo e dinâmica própria a cada obra de arte. Os elementos da ordem da expressão eram convocados pelo enunciador, que em sua mestria, arranjava-os em seus "devidos lugares", conforme o contrato fiduciário. (GREIMAS; COURTÉS, 1983, p. 86) Numa obra figurativa, por exemplo, o enunciador, mediante as figuras que escolheu enunciar, apoia-se em uma abordagem quase cartesiana de direção do olhar. Vejamos a de Picasso (figura 4.4). 
Figura 4.4

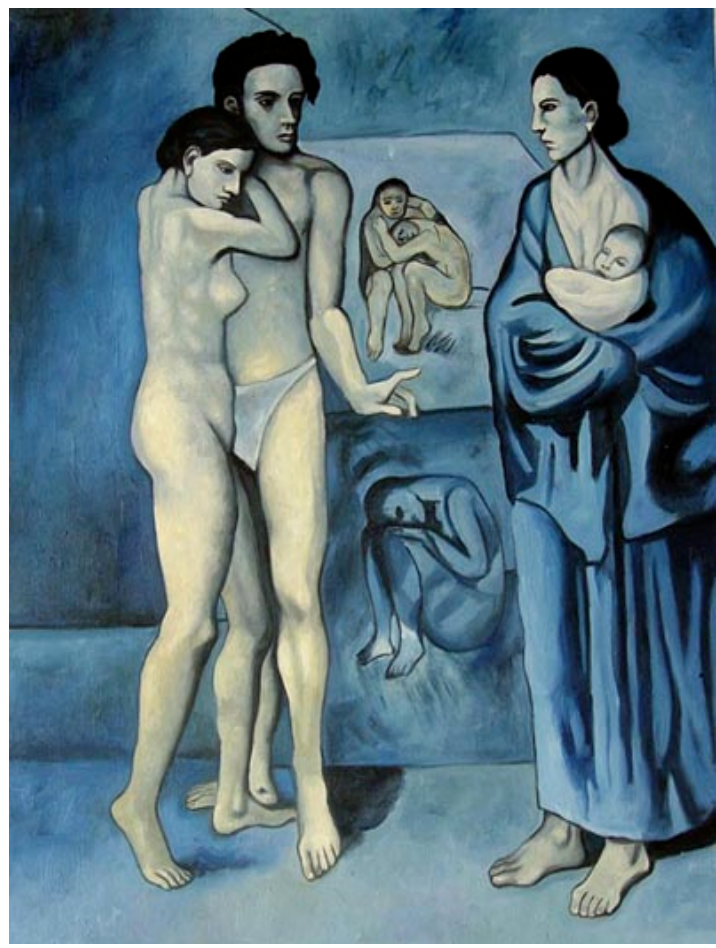

A vida

Pablo Picasso, 1903, óleo s/ tela.

Ao observarmos esse quadro, percebemos que o enunciatário cria figuras que revelam a trajetória a que conduz nosso olhar. Os olhos dos atores, por exemplo, orientam nossa apreensão de maneira circular. Vejamos as setas no detalhe a seguir:

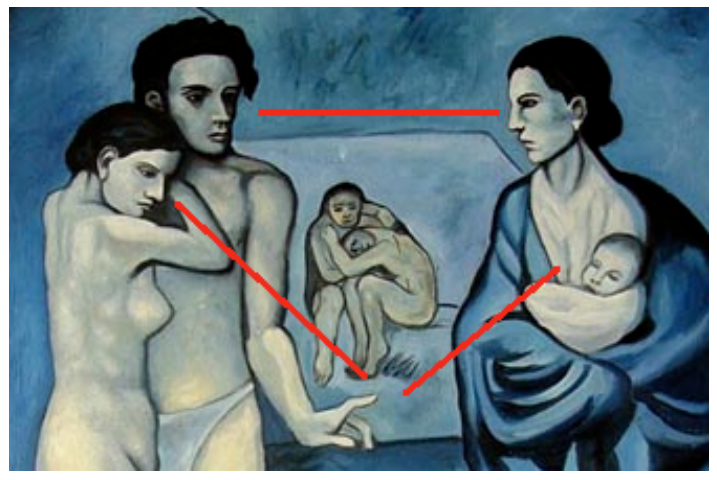

O que queremos dizer é que existem várias maneiras de conduzir o olhar do enunciatário dentro de uma obra de arte e que esses recursos são desde representações figurativas (os olhos do casal cruzando o olhar da figura da mulher que segura uma criança no colo), como também outras figuras que explicitamente apontam uma direção, como a obtusidade do cotovelo e dos seios, o dedo 
apontando para direita etc. Mas o que mais nos intriga seria como conduzir o olhar em obras da ordem da abstração, como é o caso da Série das ligas, em que a figuratividade está presente de maneira muito sutil.

\subsection{Movimento tensivo das ligas}

A dinâmica do movimento de tonificação e de atonização é verificável pelo grau de figuratividade e abstração impressos nas telas, como temos visto. Esses graus de abstração e figurativização são características que, ao longo da história da pintura, foram se transformando. Primeiramente, a teoria da arte via o conteúdo da obra de arte como sendo simplesmente assunto ou argumento tratado. Por isso, era inevitável que as pinturas fossem baseadas em uma visão objetiva e materialista. A partir da modernidade, a arte foi tomada por uma ótica mais subjetiva e foi isso que tornou possível a observação do plano do conteúdo enquanto "substância em processo de formação".

Essas características estão de acordo com a construção da Série das ligas. Podemos assim verificar no processo artístico de Duke Lee um movimento que leva à semantização e à dessemantização dos conteúdos.

Nesse caso, os conteúdos da Série das ligas podem ser tanto as ligas, propriamente ditas, quanto os meios de operação dos elementos plásticos. Essa construção artística leva-nos a identificar um movimento tensivo de preenchimento e esvaziamento semântico.

Vejamos como ficaria o movimento tensivo das Ligas, de acordo com o esquema a seguir:

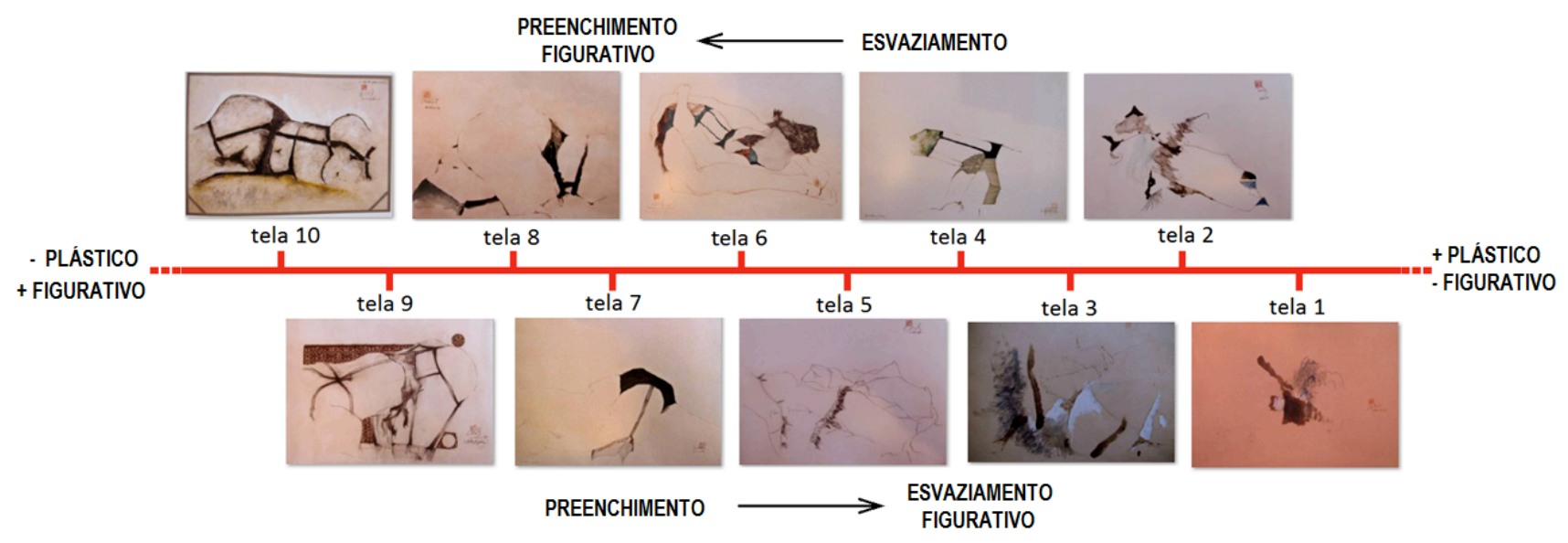


Ao longo da série, no sentido do esvaziamento (que vai da tela 10 à tela 1), o enunciador abandona o caráter mimético e figurativo e busca uma enunciação puramente plástica ${ }^{5}$ (tela 1 ).

Assim, se escolhermos a tela 4, Ode erótica a Lydia, teríamos uma tela em que há uma minimização do figurativo e que caminha para uma extinção da figuratividade, que vai levar a série a uma saturação plástica, que notamos nas telas 2 e 1.

Caso olhássemos para o movimento de preenchimento, ainda tomando a tela 4 como ponto de partida, na direção inversa, verificamos que, em relação à anterior, tela 5 , há um restabelecimento do figurativo (tela 5 , tela 6 , tela 7 ), que culminará em seu recrudescimento (telas 8,9 e 10).

Esse movimento do esvaziamento ao preenchimento é um movimento que levaria a uma saturação figurativa. Esses valores são intermitentes, o que quer dizer que, após uma saturação figurativa, teríamos uma atenuação desse excesso figurativo e caminharíamos novamente em direção à minimização figurativa até a extinção total da figuratividade. Podemos ver na figuratividade um funcionamento de pêndulo: se em maior densidade, produz um simulacro do mundo natural, de maior extensidade e, portanto, menos acelerado no sensível; se insuficiente, pode provocar a falta de reconhecimento do objeto, dando lugar à intensidade e à aceleração sensível. Esse jogo tensivo é o que denominamos, nesta dissertação, "semiótica da composição pictural", que transita entre um erotismo plástico e um erotismo figurativo.

As constantes rupturas da linha produzem um efeito de elipse, que, aliada à metonímia, configuram-se marca identitária do enunciador das Ligas e orientam o andamento do objeto para a aceleração, características dos objetos sensíveis. Na minimização de rupturas, temos um objeto preenchido orientado pelo andamento da desaceleração e de rápida apreensão inteligível. A propósito, na tela 1 , ao eleger a consoante como tônica, dificultando a apreensão do sentido, o enunciador chama a atenção para o plano da expressão. O enunciatário não pode passar por ele rapidamente, e por isso temos um objeto desacelerado no inteligível (acelerado e tônico no sensível).

\footnotetext{
${ }^{5}$ Ver observação sobre o termo plástico utilizado nesta dissertação.
} 
O espaço pode ser esvaziado e a sintaxe querer preencher o vazio; pode também o espaço ser preenchido e solicitar o esvaziamento. O esvaziamento figurativo da maioria das telas da Série das ligas advém sobretudo de um processo tensivo de um fazer artístico que elege principalmente pedaços de um corpo, fragmentos de peças íntimas, que solicitam recomposição e requerem maior participação do enunciatário. É, pois, com base nesse jogo tensivo que o enunciador propõe um erotismo mais da ordem da intensidade (plástico, esvaziado) ou mais da ordem da extensidade (figurativo, preenchido). De acordo com suas escolhas, a participação do enunciatário pode ser mais solicitada (efeito de subjetividade) ou menos (efeito de objetividade).

O preenchimento e o esvaziamento semântico estão, portanto, de acordo com a escolha do enunciador, que pode orientar-se mais pela figurativização ou mais pela abstração. Quando opta por arranjos mais plásticos, o enunciado torna-se mais sensível, requisitando mais o enunciatário, o que é evidenciado pelo contrato firmado no jogo enunciativo.

Por isso, podemos dizer que a Série das ligas é um exercício plástico em que o artista põe à prova os valores de cada elemento de sua obra e demonstra, em seu fazer, a dependência dos elementos plásticos (traço, linhas, volume), cuja articulação dá ritmo e dinamiza a obra de arte. Isso produz um objeto dinâmico, cujo movimento tensivo se dá em um contínuo de preenchimento e de esvaziamento. 


\section{CONCLUSÃO}

A análise semiótica da Série das ligas com base em conceitos de tensividade nos orientou a compreensão da obra de Wesley Duke Lee. Verificamos que a maioria das telas é marcada pela escolha de um andamento acelerado no sensível, produto sobretudo de uma enunciação apoiada na metonímia (que prefere apresentar partes de um corpo feminino a apresentá-lo em sua totalidade) e por elipses dos traços (descontinuidade dos contornos e das linhas) que provocam efeitos de aceleração na percepção do objeto, bem como requisitam um enunciatário para preencher o objeto esvaziado semanticamente.

Inicialmente, analisamos como o caráter subjetivo ou objetivo de uma obra de arte pôde contribuir para o estreitamento da relação de fruição estética entre enunciador e enunciatário. Desse modo, pudemos reconhecer na Série das ligas um efeito de sentido de objetividade e subjetividade que contribuiu para o engendramento de dois tipos de erotismo: um mais plástico (menos mimético e mais abstrato) e outro menos plástico (mais mimético ou mais figurativo e menos abstrato), este se acentuando à proporção que aquele se atenua. No primeiro caso, há uma aproximação e um efeito de subjetividade. Nesse caso, temos uma enunciação enunciada. No segundo caso, o de um erotismo figurativo, mais mimético, temos um distanciamento e um efeito de sentido de objetividade.

Há, portanto, um erotismo que distancia ou aproxima a instância da enunciação de seu objeto. Na constituição objetiva, a participação do enunciatário é menor, já que as formas são preenchidas; na constituição subjetiva, existe uma construção esvaziada, que sugere um complemento, o que caracterizaria o tipo de erotismo presente na obra como um erotismo mais plástico, portanto.

Esse efeito de preenchimento e de esvaziamento, produzido pela figurativização (objetividade) ou plasticidade (subjetividade), é também resultado da escolha de elementos expressivos em sua composição. $O$ artista ora escolhe elementos expressivos da ordem do desenho, ora elementos expressivos da ordem 
da pintura. A série em análise oscila entre um desenho e uma pintura, de acordo com as coerções técnicas dos materiais utilizados na produção de suas telas.

Assim, quando a enunciação escolhe a plasticidade, fogem-lhe as ligas; todavia, se escolhe o efeito mimético, o objeto se aproxima do simulacro do mundo natural e as ligas aparecem com mais ênfase. É esse jogo de plástico e figurativo, de esvaziar e de preencher, que incita o enunciatário e o leva a degustar esse objeto como menos ou mais estético.

Em um segundo momento, fizemos um estudo do léxico erotismo, que nos ajudou a entender o impulso erótico próximo, mutatis mutandis, ao impulso estético: o de querer estar em conjunção com o objeto de desejo.

Vimos também que a Série das ligas orienta-se pela oposição fundamental entre exterioridade (roupas íntimas) e interioridade (corpo). O enunciador vai gradativamente despindo seu objeto para penetrar-lhe as entranhas, um desejo erótico não só de possuir seu objeto, mas também de descobrir o que se passa no seu interior, o que pudemos verificar quando analisamos a tela 1, no capítulo 4 .

No exame da Série das ligas, identificamos que não é o erotismo propriamente que se eleva à condição de objeto central de sua composição, pois que ele é apenas porta de entrada para a penetração no interior do feminino. Ele desveste o objeto em busca dos mistérios que o envolve. Nesse sentido, metalinguisticamente faz o mesmo caminho de um artista em busca dos mistérios da arte: a beleza estética. Vai paulatinamente afastando-se da figuratividade para ocupar-se cada vez mais da pintura. Não se trata, pois, de apresentar um sujeito desvestindo a amada e jogando suas peças intimas para os ares, mas de um artista que identifica feminino e arte e ocupa-se do que é próprio a esta última.

Verificamos que o sentido promovido pelo enunciado das telas contribui para a formação de uma identidade do enunciador como artista dotado de sensibilidade, refinado, econômico nos traços e em sintonia com as tendências artísticas europeias e norte-americanas. Em alguns momentos, percebemos um enunciador oscilante entre o traço nervoso e aparentemente instintivo e o equilíbrio das emoções feito pela razão, como um regulador daquilo que as primeiras sensações imprimiram no papel, ora se mostrando mais, ora se escondendo mais. Nas palavras de Lorenzo Mammì, "todas as suas obras buscam metaforicamente, e que me parece ser o impulso fundamental de seu trabalho: o desejo de estar sempre presente na obra, 
em todos os lugares e todos os momentos, de forma ao mesmo tempo chamativa e escondida" (MAMMì, 2012, p. 328).

Outro resultado alcançado diz respeito ao encaminhamento semântico que pode ser dado às lâminas que compõem nosso corpus. As imagens vão paulatinamente esvaziando-se de figuratividade e recompondo-se em apenas sugestões de traços, cores e linhas.

A Série das ligas constitui-se uma composição pictural em que o artista coloca em jogo os valores plásticos de sua obra e demonstra, em seu fazer, a dependência dos elementos do plano da expressão (traço, linhas, volume), cuja articulação dá ritmo à obra de arte, produzindo um objeto dinâmico, cujo movimento tensivo se dá em um contínuo de preenchimento e de esvaziamento e promove a nostalgia da perfeição, da duração que não dura. 


\section{REFERÊNCIAS}

AGUILERA, Yanet (Org.). Entre quadros e esculturas: Wesley Duke Lee e os fundadores da escola Brasil:. São Paulo: Discurso Editorial, 1997.

ALBERONI, Francesco. O erotismo: fantasias e realidades do amor e da sedução. Tradução de Élia Edel. São Paulo: Círculo do Livro, 1986.

AMOSSY, Ruth (Org.). Imagens de si no discurso: a construção do ethos. São Paulo: Contexto, 2008.

ANDRADE, Sebastião Costa. Desejos desvelados: erotismo e pornografia numa perspectiva macrossociológica. Curitiba: Instituto Memória, 2009.

ARGAN, Giulio Carlo. Imagem e persuasão. Tradução de Mauricio Santana Dias. São Paulo: Companhia das Letras, 2004.

ARNHEIM, Rudolf. Arte e percepção visual: uma psicologia da visão criadora. São Paulo: Pioneira, 1986.

BADE, Patrick. Henri de Toulouse-Lautrec. New York: Parkstone, 2000.

BARTHES, Roland. O óbvio e o obtuso. Tradução de Isabel Pascoal. Porto: Edições $70,1984$.

A câmara clara. Tradução de Júlio Castañon Guimarães. Rio de Janeiro: Nova Fronteira, 2008.

BATAILLE, Georges. O erotismo. Tradução de Fernando Scheibe. Belo Horizonte: Altântica Editora, 2013.

BAUDRILLARD, Jean. A troca impossível. Rio de Janeiro: Nova Fronteira, 2002.

BIRMAN, Joel. Gramáticas do erotismo: a feminilidade e as suas formas de subjetivação em psicanálise. Rio de Janeiro: Civilização Brasileira, 2001.

BRANCO, Lúcia Castello. O que é erotismo. São Paulo: Brasiliense, 1984.

CABRAL, Antonio Helio. Volta à figura: a década de 60. Museu Lasar Segall, maio/jun. 1979 (catálogo).

CALABRESE, Omar. A linguagem da arte. Tradução de Tânia Pelegrini. Rio de Janeiro: Globo, 1987.

CANTON, Katia. Corpo, identidade e erotismo. São Paulo: Martins Fontes, 2011. 
CHIARELLI, Tadeu. Um modernismo que veio depois: arte no Brasil - primeira metade do século XX. São Paulo: Alameda, 2012.

COSTA, Cacilda Teixeira da (Org.). Antologia crítica sobre Wesley Duke Lee. São Paulo: Galeria Paulo Figueiredo, 1981. Catálogo.

. Arte no Brasil 1950-2000: movimentos e meios. São Paulo: Alameda, 2009.

. Wesley Duke Lee. Rio de Janeiro: Pinakotheke, 2010.

. Wesley Duke Lee: um salmão na corrente taciturna. São Paulo: Alameda:

Edusp, 2005.

COUTO, Maria de Fátima Morethy. Por uma vanguarda nacional. Campinas: Editora Unicamp, 2004.

DELEUZE, Gilles. Francis Bacon: lógica da sensação. Tradução de Roberto Machado; Aurélio Guerra Neto; Bruno Lara Resende; Ouvídio de Abreu; Paulo Germano de Albuquerque e Tiago Seixas Themudo. Rio de Janeiro: Jorge Zahar, 2007.

- Sacher-masoch: o frio e o cruel. Tradução de Jorge Bastos. Rio de Janeiro: Jorge Zahar, 2009.

DIDEROT. Obras II: estética, poética e contos. Organização, tradução e notas de J. Guinsburg. São Paulo: Perspectiva, 2000.

DORFLES, Gillo. O devir das artes. Tradução de Pier Luigi Cabra. São Paulo: Martins Fontes, 1992.

FABBRI, Paolo. Introdução. In: GREIMAS, A. Julien. Da imperfeição. Tradução de Ana Claudia de Oliveira. São Paulo: Hacker, 2002. p. 95-111.

FERREIRA, Glória; COTRIM, Cecília. (Org.). Escritos de artistas: anos 60/70. Rio de Janeiro: Jorge Zahar, 2006.

FIORIN, José Luiz. As astúcias da enunciação: as categorias de pessoa, espaço e tempo. São Paulo: Ática, 1996.

. Elementos de análise do discurso. São Paulo: Contexto, 2008.

FISCHER, Ernst. A necessidade da arte. Tradução de Leandro Konder. Rio de Janeiro: Jorge Zahar, 1976.

FLOCH, Jean-Marie. Petites mythologies de l'oeil et de l'esprit: pour une sémiotique plastique. Paris: Éditions Hadès-Benjamins, 1985.

FONTANILLE, Jacques. Semiótica do discurso. Tradução de Jean Cristtus Portela. São Paulo: Contexto, 2007. 
FONTANILLE, Jacques; ZILBERBERG, Claude. Tensão e significação. Tradução de Ivã Carlos Lopes, Luiz Tatit e Waldir Beividas. São Paulo: Discurso Editorial: Humanitas, 2001.

FRANCASTEL, Pierre. A realidade figurativa. Tradução Mary Amazonas Leite de Barros. 3. ed. São Paulo: Perspectiva, 2011.

GERHEIM, Fernando. Linguagens inventadas: palavra, imagem, objeto: formas de contágio. Rio de Janeiro: Jorge Zahar, 2008.

GILOT, Françoise; LAKE, Carlton. A minha vida com Picasso. Tradução de Carmen Gonzales e Antonio Ramos Rosa. São Paulo: Samambaia, 1960.

GOMBRICH, E. H. A história da arte. Tradução de Álvaro Cabral. 16. ed. Rio de Janeiro: LTC, 2009.

. Meditações sobre um cavalinho de pau: e outros ensaios sobre a teoria da arte. Tradução de Geraldo Gerson de Souza. São Paulo: Edusp, 1999.

GREIMAS. A. J. Da imperfeição. Tradução de Ana Claudia de Oliveira. São Paulo: Hacker, 2002.

(Org.). Ensaios de semiótica poética. Tradução de Heloysa de Lima Dantas. São Paulo: Cultrix, 1975.

. Semiótica do discurso científico: da modalidade. Tradução de Cidmar Teodoro Pais. São Paulo: Difusão Editorial, 1976.

- Sobre o sentido: ensaios semióticos. Tradução de Ana Cristina Cruz Cezar et al. Petrópolis: Vozes, 1975.

Semiótica figurativa e semiótica plástica. Significação: Revista Brasileira de Semiótica, n. 4, jun. 1984.

; COURTÉS, J. Dicionário de semiótica. Tradução de Alceu Dias Lima et al. São Paulo: Cultrix, 1983.

Paris: Hachette, 1986. v. 2.

GOULEMOT, Jean-Marie. Esses livros que se lêem com uma só mão: leitura e leitores de livros pornográficos no século XVIII. Tradução de Maria Aparecida Corrêa. São Paulo: Discurso Editorial, 2000.

HJELMSLEV, Louis. Prolegômenos a uma teoria da linguagem. Tradução de J. Teixeira Coelho Netto. 2. ed. São Paulo: Perspectiva, 1975/2009.

HOUAISS, Antônio; VILLAR, Mauro Salles. Dicionário Houaiss da Língua Portuguesa. Rio de Janeiro: Objetiva, 2001. 
JAKOBSON, Roman. Linguística e comunicação. Tradução de Izidoro Blikstein e José Paulo Paes. 20. ed. São Paulo: Cultrix, 2005.

JANSON, H. W.; JANSON, A. F. Iniciação à história da arte. Tradução de Jefferson Luis Camargol. São Paulo: Martins Fontes, 2000.

LANDOWSKI, Eric; FIORIN, José Luiz. O gosto da gente, o gosto das coisas: abordagem semiótica. São Paulo: Educ, 1997.

. Presenças do outro. São Paulo: Perspectiva, 2005.

; DORRA, Raúl; OLIVEIRA, Ana Claudia de. Semiótica, estesis, estética.

São Paulo: Educ; Puebla: UAP, 1999.

LICHTENSTEIN, Jacqueline. A cor eloquente. Tradução Maria Elizabeth Chaves de Mello e Maria Helena de Mello Rouanet. São Paulo: Siciliano, 1994.

(Org.). A ideia e as partes da pintura. São Paulo: Editora 34, 2008.

(Org.). A figura humana. São Paulo: Editora 34, 2008.

(Org.). Da imitação à expressão. São Paulo: Editora 34, 2008.

(Org.). O desenho e a cor. São Paulo: Editora 34, 2008.

(Org.). Os gêneros pictóricos. São Paulo: Editora 34, 2008.

LOPES, Fernanda. A experiência Rex: éramos o time do Rei. São Paulo: Alameda, 2009.

MAINGUENEAU, Dominique. O discurso pornográfico. Tradução de Marcos Marcionilo. São Paulo: Parábola Editorial, 2010.

MAMMì, Lorenzo. O que resta: arte e crítica de arte. São Paulo: Companhia das Letras, 2012.

MATTOS, Franklin de. A cadeia secreta. São Paulo. Cosac \& Naify. 2004.

MAYER, Ralph. Manual do artista. Tradução de Christine Nazareth. São Paulo: Martins Fontes, 2006.

MEDEIROS, João Bosco. Redação científica: a prática de fichamentos, resumos, resenhas. 11. ed. São Paulo: Atlas, 2009.

; TOMASI, Carolina. Redação técnica: elaboração de relatórios técnicocientíficos e técnica de normalização textual. 2. ed. São Paulo: Atlas, 2010.

NAVES, Rodrigo. O vento e o moinho: ensaios sobre arte moderna e contemporânea. São Paulo: Companhia das Letras, 2007.

OLIVEIRA, Ana Claudia de (Org.). Semiótica plástica. São Paulo: Hacker, 2004.

OSTROWER, Fayga. Universos da arte. Rio de Janeiro: Campos, 1986. 
PAZ, Octavio. Marcel Duchamp: ou o castelo da pureza. Tradução de Sebastião Uchoa Leite. São Paulo: Perspectiva, 2008.

PERNIOLA, Mario. Pensando o ritual: sexualidade, morte, mundo. Tradução de Maria do Rosário Toschi. São Paulo: Studio Nobel, 2000.

PIETROFORTE, Antonio Vicente. Análise do texto visual: a construção da imagem. São Paulo: Contexto, 2007. . Enunciação e tensividade. São Paulo: Annablume, 2010.

PIETROFORTE, Antonio Vicente. O discurso da poesia concreta: uma abordagem semiótica. São Paulo: Annablume, 2011. Semiótica visual: os percursos do olhar. São Paulo: Contexto, 2004.

PINHEIRO, Olympio Jose; PANTALEÃO, Lucas. O ciclo percepção-expressão: uma abordagem holística da realidade a partir da arte. Revista Poiésis, n 18, dez. 2011. p. 57-72.

PIVA, Roberto. Paranóia. 3. ed. São Paulo: Instituto Moreira Salles, 2009.

READ, Herbert. $A$ arte de agora, agora: uma introdução à teoria da pintura e escultura modernas. São Paulo: Perspectiva, 1981.

REIS, Paulo R. O. Arte de vanguarda no Brasil: os anos 60. Rio de Janeiro: Jorge Zahar, 2006.

RESTANY, Pierre. Os novos realistas. São Paulo: Perspectiva, 1979.

RIVERA, Tania. Arte e psicanálise. Rio de Janeiro: Jorge Zahar, 2005.

ROSENBERG, Harold. A tradição do novo. Tradução de Cesar Tozzi. São Paulo: Perspectiva, 1974.

SALZSTEIN, Sônia (Org.). Matisse: imaginação, erotismo e visão decorativa. Tradução de Desnise Bottmann. São Paulo: Cosac \& Naify, 2009.

SAUSSURE, Ferdinand de. Curso de linguística geral. Tradução de Antônio Chelini, José Paulo Paes e Izidoro Blikstein. São Paulo: Cultrix, 1996.

SCHMIDT, Georg. Pequena história da pintura moderna. Tradução de Fredy van Camp. Rio de Janeiro: Bloch, 1969.

SILVA, Ignácio Assis (Org.). Corpo e sentido: a escuta do sensível. São Paulo: Editora da Unesp, 1996.

TATIT, Luiz. Análise semiótica através das letras. São Paulo: Ateliê Editorial, 2001. . Musicando a semiótica. São Paulo: Annablume, 1997. . Semiótica à luz de Guimarães Rosa. São Paulo: Ateliê Editorial, 2010. 
TATIT, Luiz. Todos entoam: ensaios, conversas e canções. São Paulo: Publifolha, 2007.

; LOPES, Ivã Carlos. Elos de melodia e letra: análise semiótica de seis canções. São Paulo: Ateliê Editorial, 2008.

TEIXEIRA, Lucia. As cores do discurso. Niterói: Eduff, 1996.

TOMASI, Carolina. Elementos de semiótica: por uma gramática tensiva do visual. São Paulo: Atlas, 2012.

WÖLFFLIN, Heinrich. Conceitos fundamentais da história da arte. Tradução de João Azenha Jr. 4. ed. São Paulo: Martins Fontes, 2006.

ZILBERBERG, Claude. Razão e poética do sentido. Tradução de Ivã Carlos Lopes, Luiz Tatit e Waldir Beividas. São Paulo: Edusp, 2006.

. Elementos de gramática tensiva. Tradução de Ivã Carlos Lopes, Luiz Tatit e Waldir Beividas. São Paulo: Ateliê Editorial, 2011. 
ANEXO

Dez Lâminas da Série das Ligas. 


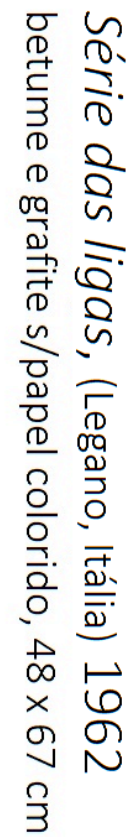

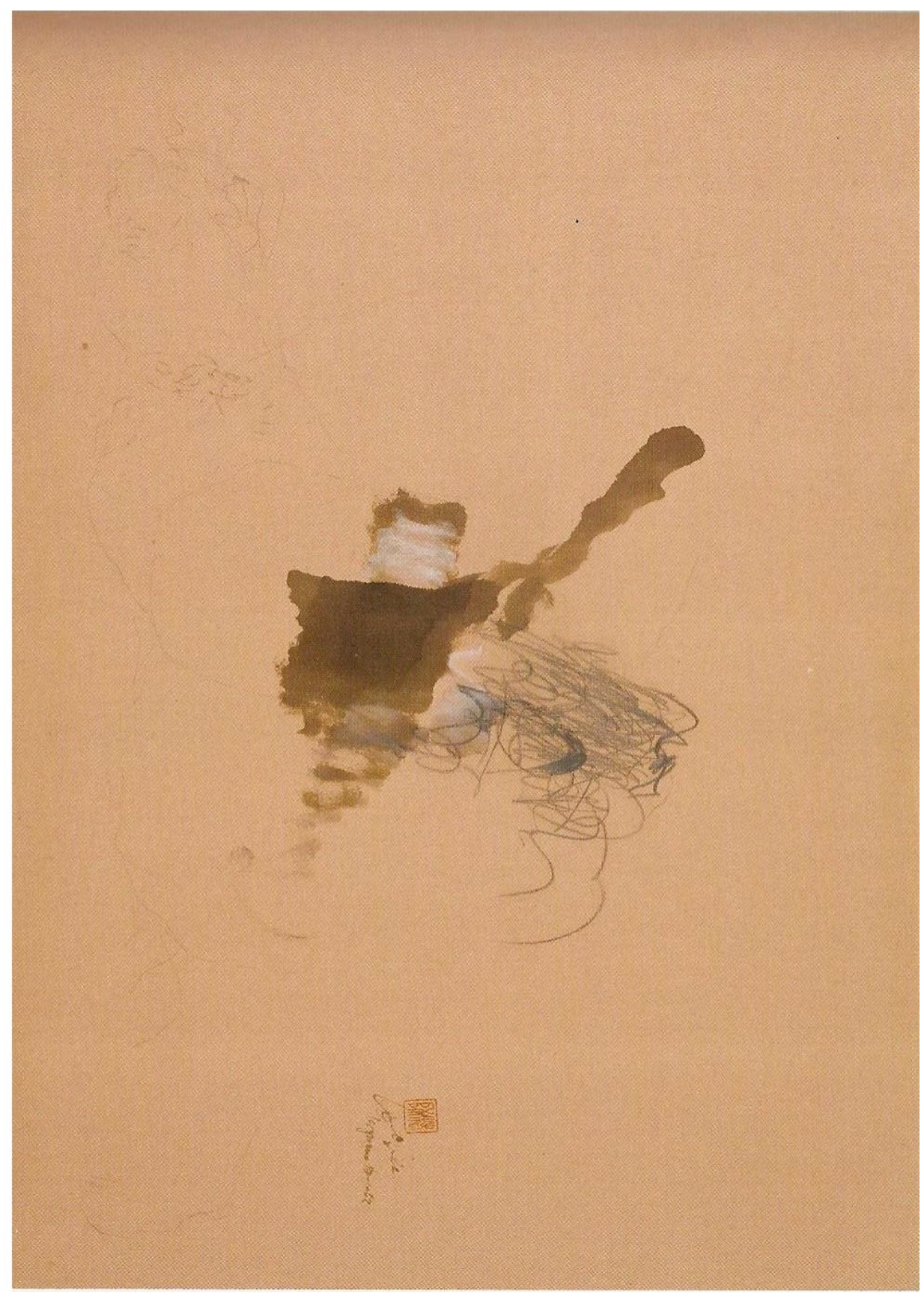



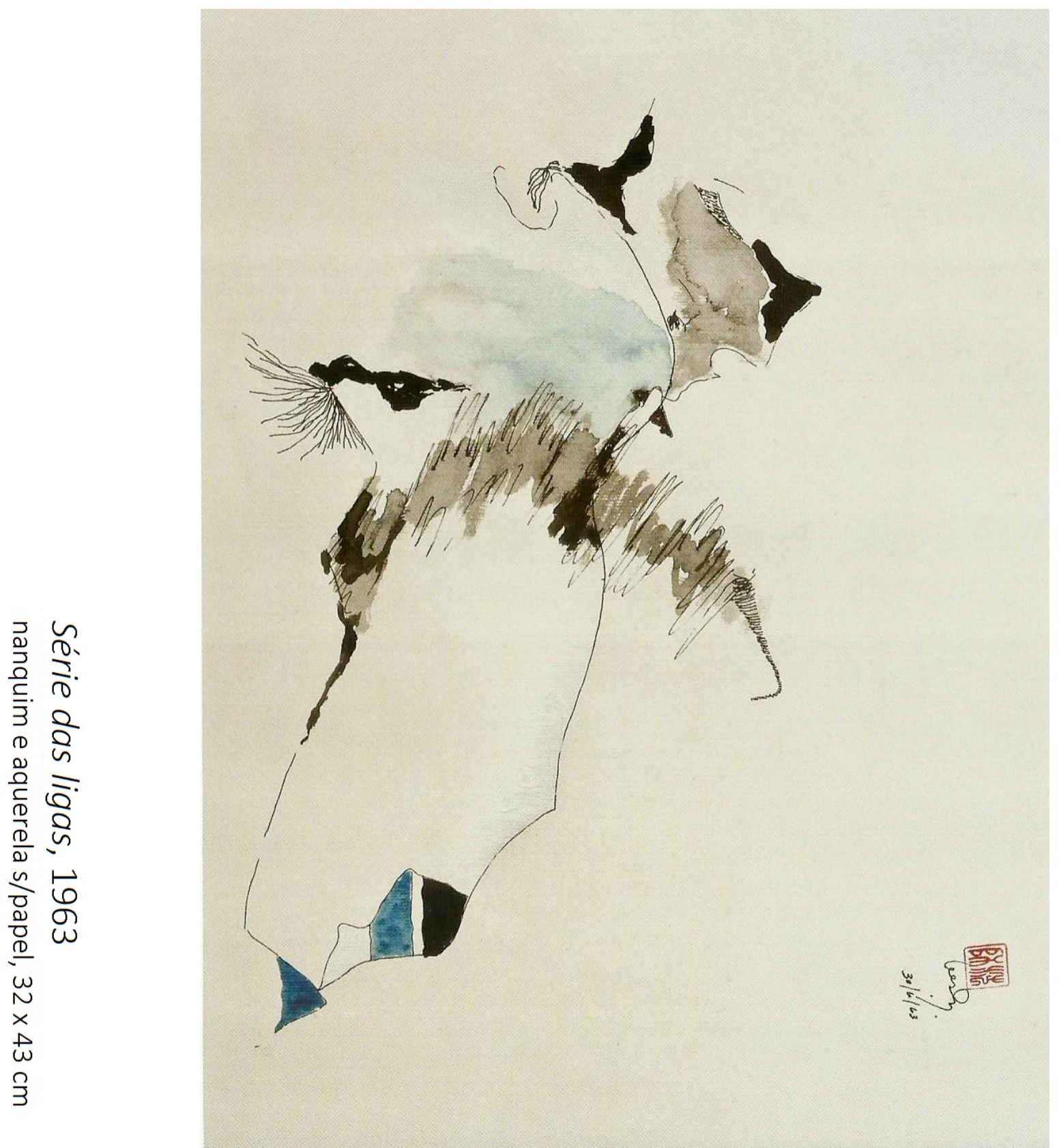

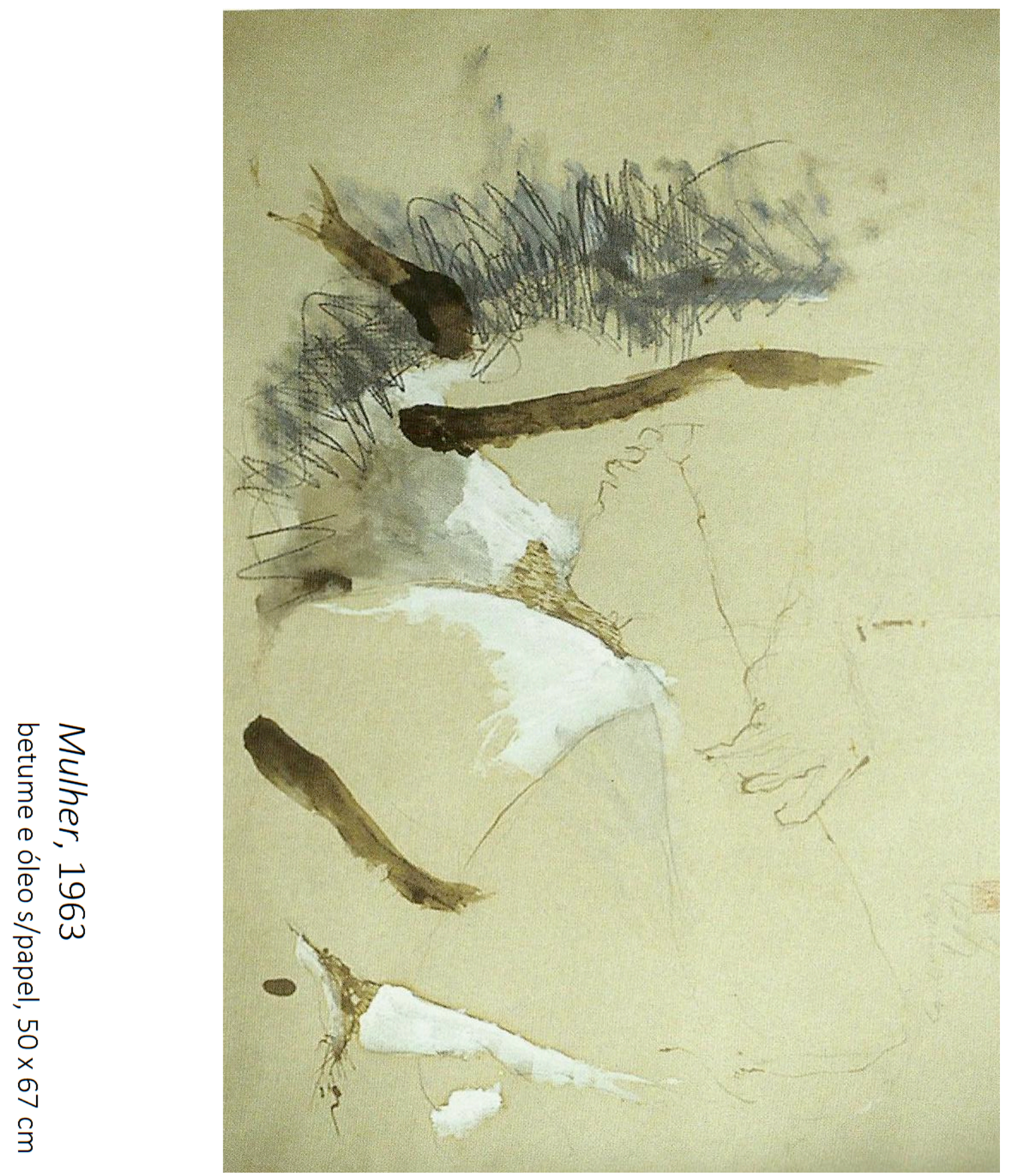

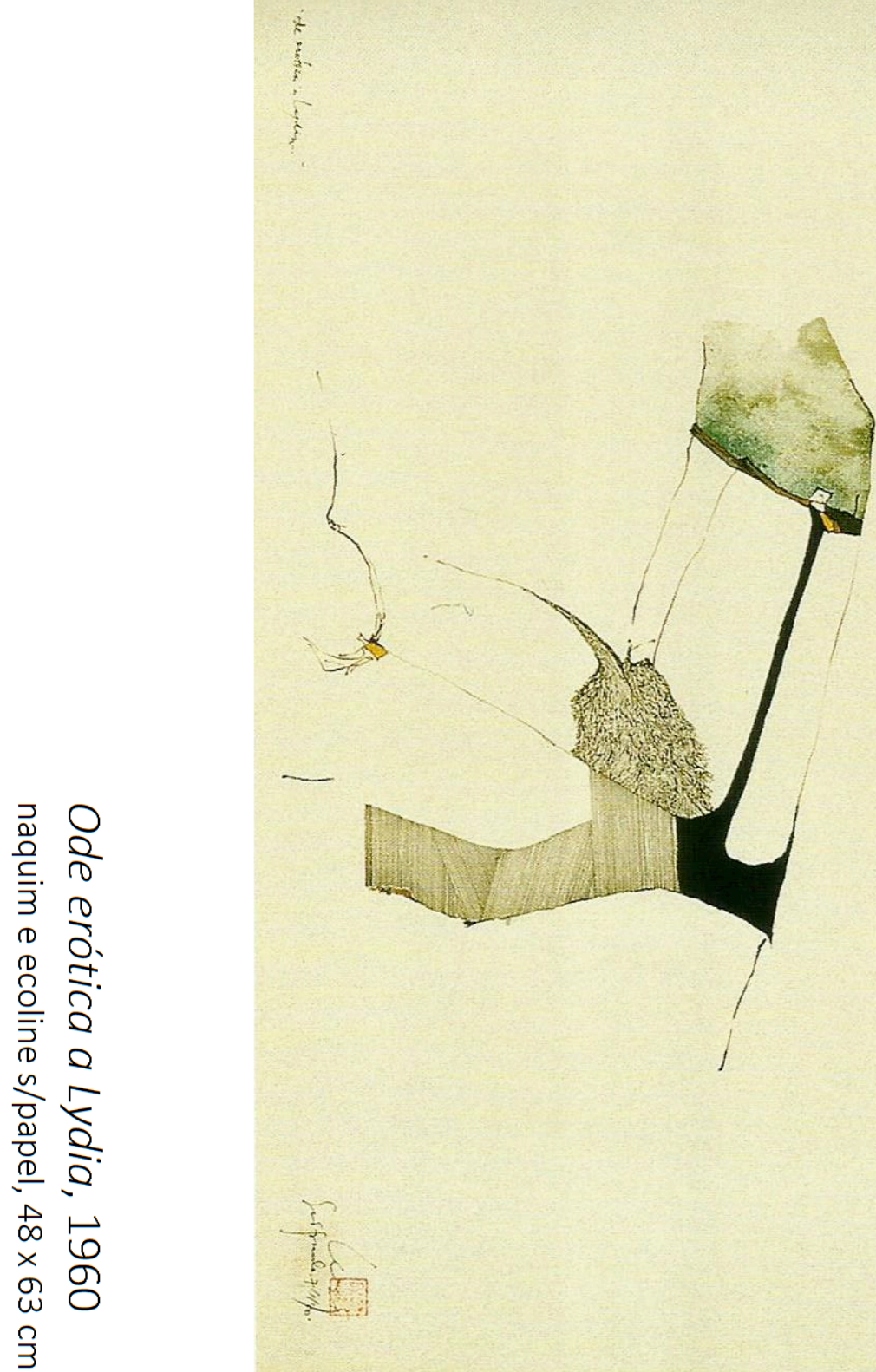

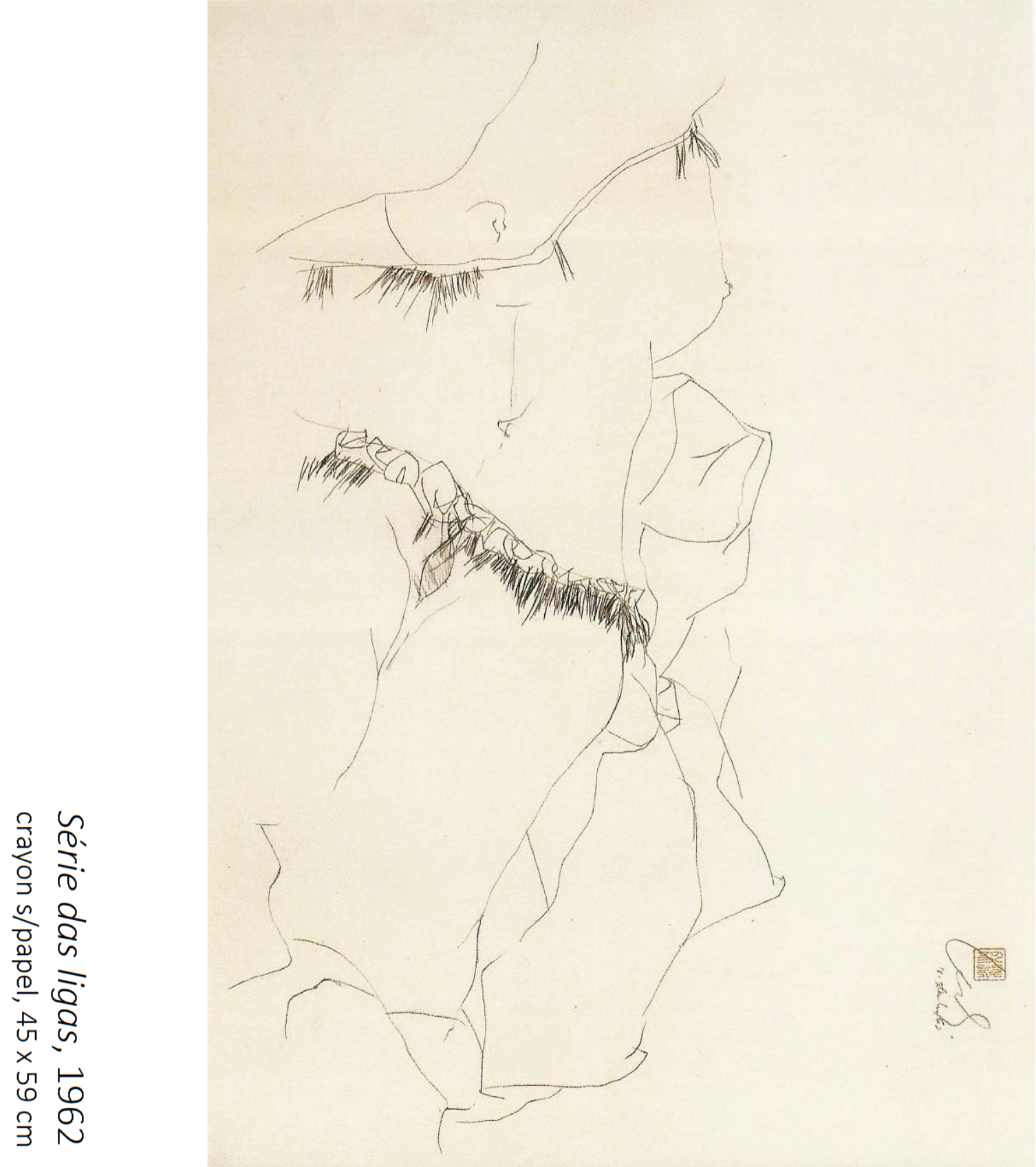

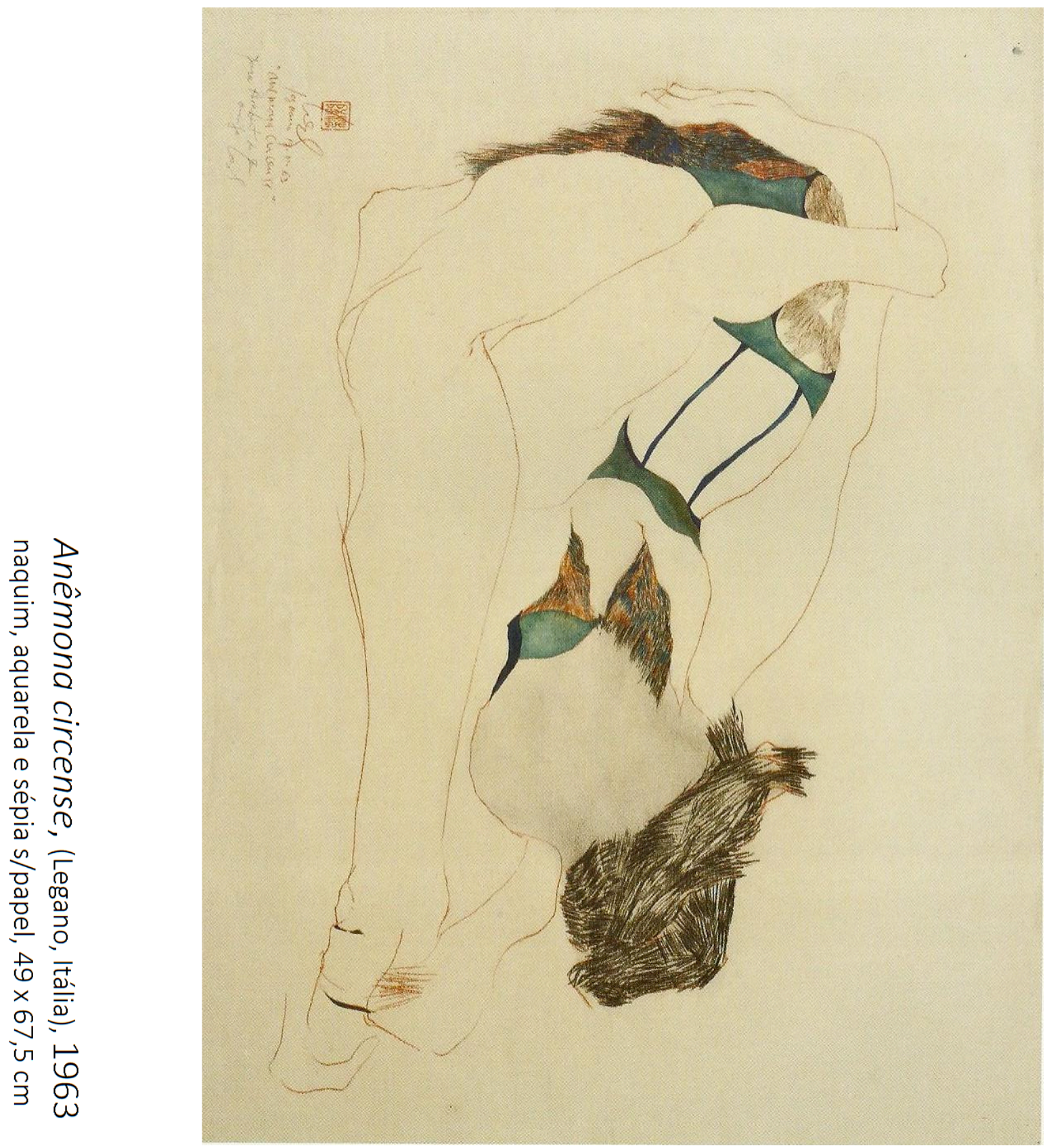


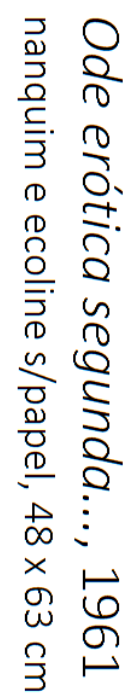

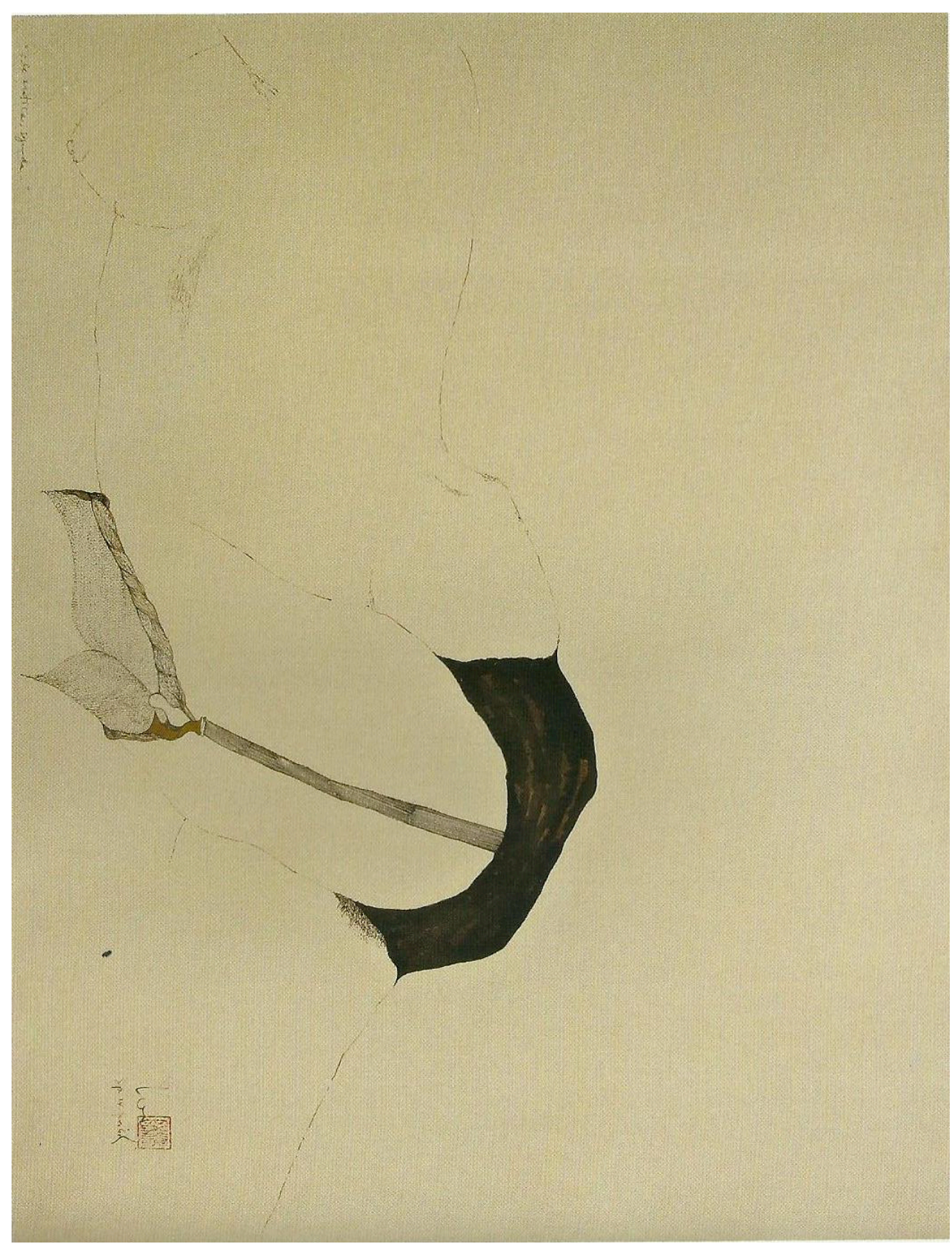



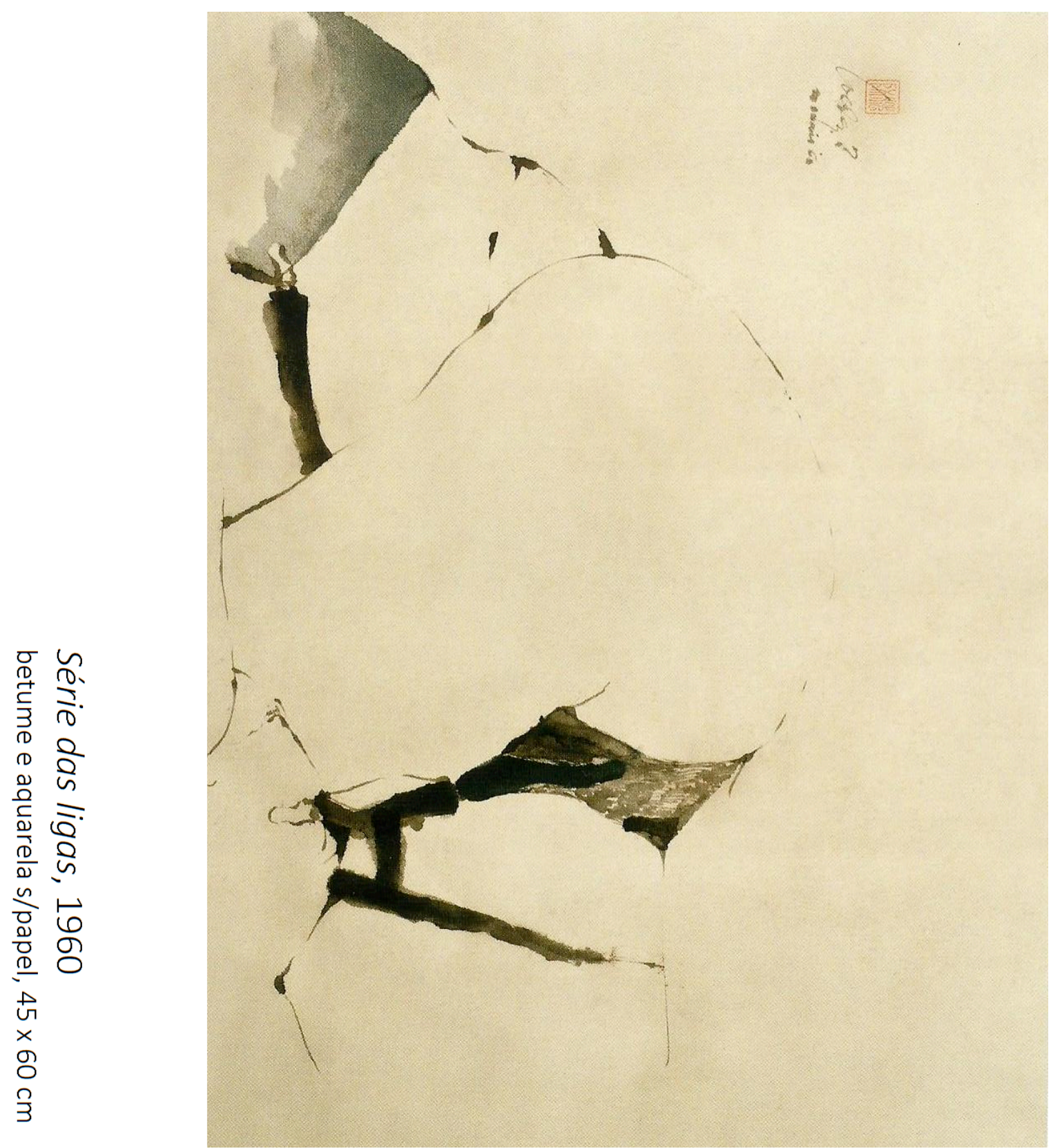




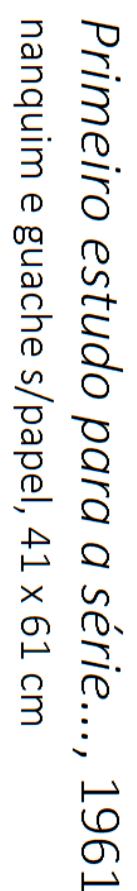

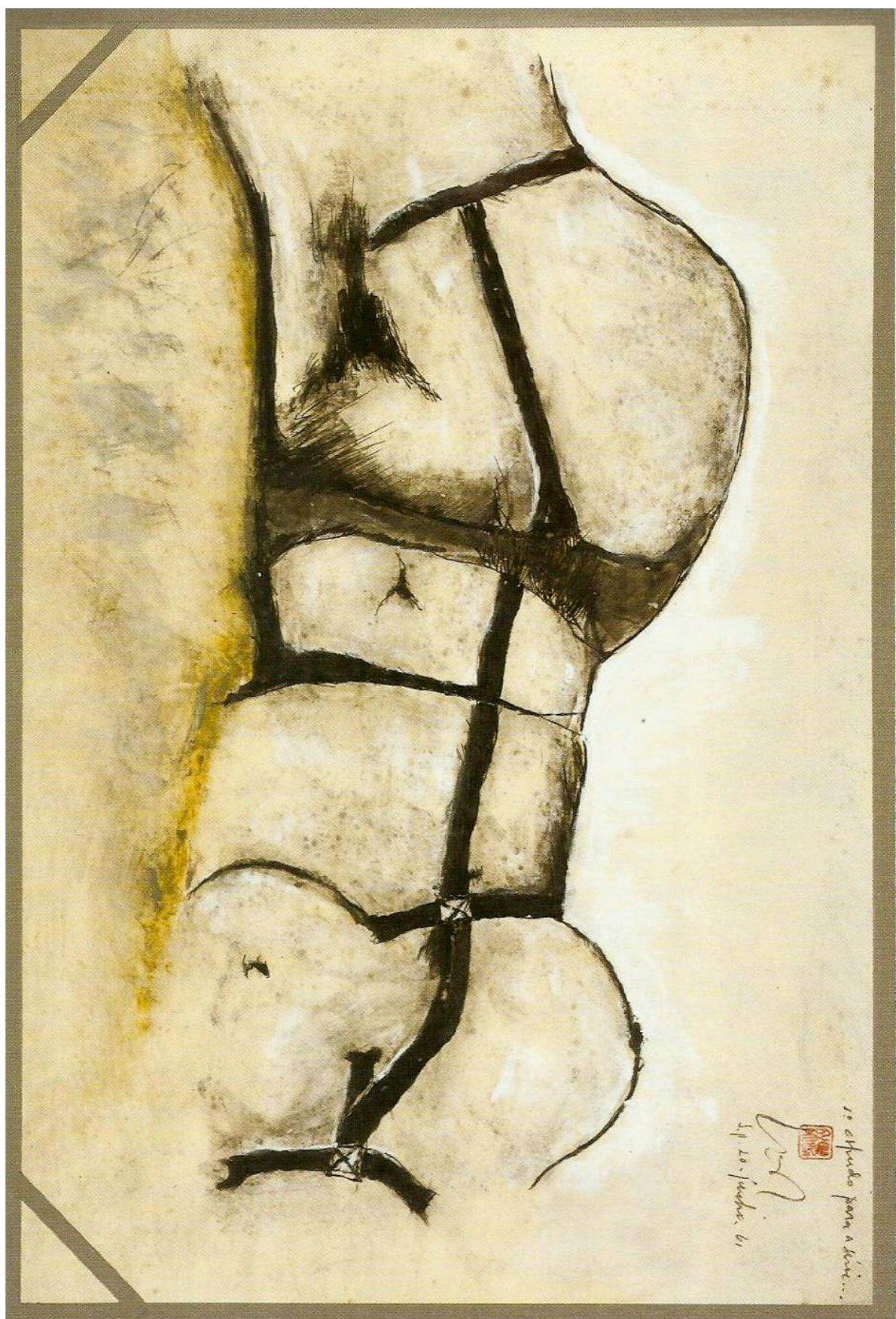




\section{Índice de imagens}

Banho, de William Bouguereau, 1870, 18

Amazona ferida, de Policleto, séc. V a.C., 18

As grandes banhistas, de Cézanne, 1898-1900, 19

Primeiro estudo para a Série..., de Wesley Duke Lee, 1961, 22

Série das Ligas, de Wesley Duke Lee, 1962, 23

Hoje é sempre ontem, de Wesley Duke Lee, 1964-1972, 24

A praia, de Wesley Duke Lee, 1963, 25

Composição II em vermelho, azul e amarelo, de Mondrian, 1930, 27

A noiva despida pelos seus celibatários, mesmo, Marcel Duchamp, 1915-1923, 29

Desenho indígena/Detalhe de vaso grego/Detalhe de afresco egípcio, Victor

Vasarely, 31

Tempestade de neve: navio ao largo do porto, de Turner, 1842, 33

Campo de trigo com corvos (detalhe), de Van Gogh, 1890, 34

Café, de Portinari, 1934-1935, 36

Retorno à base dy Saint-Amér, de Wesley Duke Lee, 1977, 39

Tracer, de Rauschenberg, 1963, 39

Eliezer e Rebecca, de Poussin, 1648, 44

Eliezer e Rebecca, de Rousselet, 1677, 45

Aparelho para o tratamento magnético de plantas, Paul Klee, 1908, 45

São os dois últimos, de Wesley Duke Lee, 1959, 46

Hilda Angélica / Anêmona Circense / Ode erótica a Lydia (Série das Ligas), de Wesley Duke Lee, 51

O nome do cadeado é: as circunstâncias e seus guardiões tríptico composto de: o guardião, o cadeado, a guardiã, de Wesley Duke Lee, 1966, 51

Série das Ligas, de Wesley Duke Lee, 1963, 58

Série das Ligas (Hilda Angélica), de Wesley Duke Lee, 1962, 61

O festim de Baltazar, Rembrandt, 1635, 66 
A banheira, de Degas, 1886, 69

Estudo de perna, Michelângelo, 1508-1512, 72

Estudo para adoração dos reis magos, de Leonardo da Vinci, 1481-1482, 73

Série das Ligas, de Wesley Duke Lee, 1963, 73

Luxo, calma e volúpia, de Matisse, 1904, 84

A Maja vestida, de Goya, 1802-1805, 85

Sem título [toquinho], de Mira Schendel, 1972, 86

Sem título, de Eduardo Sued, 1988, 88

Nu azul II, de Matisse, 1950-1952, 90

Ode erótica a Lydia, 1960, 90

Detalhe de A criação de Adão, de Michelangelo, 1508-1512, 94

Série das Ligas, de Wesley Duke Lee, 1960, 96

Conjunto de quatro ligas, de Wesley Duke Lee, 97

Série das Ligas, de Wesley Duke Lee, 1960, 99

Fuzilamentos de 3 de maio de 1808, de Goya, 1914, 103

O sena e a grande Jatte na primavera, de Seurat, 1887, 107

Composição II em vermelho, azul e amarelo, de Mondrian, 1930, 109

Sem título XXV, de Kooning, 1877, 110

Série das Ligas, de Wesley Duke Lee, 112-115, 117, 123 (movimento tensivo das ligas)

A vida, de Picasso, 1903, 122 